Felipe Augusto de Moraes

\title{
A Arte-Soma de José Agrippino de Paula
}

Dissertação apresentada ao Programa de PósGraduação em Meios e Processos Audiovisuais da Escola de Comunicações e Artes da Universidade de São Paulo, como exigência parcial para a obtenção do título de Mestre.

São Paulo 


\title{
Universidade de São Paulo \\ Escola de Comunicações e Artes
}

\section{A Arte-Soma de José Agrippino de Paula}

\author{
Felipe Augusto de Moraes
}

Dissertação apresentada ao Programa de PósGraduação em Meios e Processos Audiovisuais da Escola de Comunicações e Artes da Universidade de São Paulo, como exigência parcial para a obtenção do título de Mestre.

Linha de Pesquisa: Teoria, História e Crítica

Orientador: Prof. Dr. Ismail N. Xavier

São Paulo 


\title{
A Arte-Soma de José Agrippino de Paula
}

\author{
Felipe Augusto de Moraes
}

Folha de Aprovação

Banca Examinadora:

Orientador:

Instituição:

Assinatura:

Prof. Dr.

Instituição:

Assinatura:

Prof. Dr.

Instituição:

Assinatura:

Data:

1




\section{Agradecimentos}

À Fundação de Amparo a Pesquisa do Estado de São Paulo, pela bolsa de mestrado concebida que possibilitou a realização desta pesquisa.

Ao professor Ismail Xavier, pela orientação prestimosa e segura, e também pela generosidade em ter acreditado na proposta de um aluno desconhecido, com uma vocação titubeante para os estudos fílmicos.

À professora Silvia Fernandes, pelos comentários precisos na banca de qualificação, e ao professor Rubens Machado Jr., amigo de passeatas, aulas, jantares e conversas, muitas conversas; e filmes também, claro, especialmente estas pepitas experimentais (e marginais) a quem dedicamos tanto de nosso tempo e apreço.

Aos amigos da graduação e pós-graduação, especialmente Joeferson Almeida que esteve presente em discussões e descobertas desde o dia em que assistimos juntos a exibição de Hitler III ${ }^{\circ}$ Mundo na Galeria Olido (exibição esta que, de certa maneira, deu origem a esta pesquisa) até o exato momento em que escrevo estes agradecimentos.

Aos amigos e parentes da gloriosa e invernal São Roque, que toleraram desde cedo minha predileção pelas esquisitices poéticas, apoiando, sempre que razoável (e, com certa frequência, mesmo quando não), com respeito e carinho minha vocação em ser gauche na vida.

À Agrippino e Maria Esther, soma de arte e vida.

E por fim, e mais importante, a Célia, minha mãe; a ela devo o amor, e a ela dedico este trabalho. 
"A véspera do fim do mundo foi o único dia que prestou."

trecho do filme Sem Essa, Aranha 


\section{Resumo}

Esse trabalho acompanha a trajetória artística do escritor, teatrólogo e cineasta José Agrippino de Paula do lançamento de seu primeiro romance, Lugar Público, em 1965, até algumas de suas experiências com filmes Super-8 já na década de 70. Como eixo fundamental, ele relata criticamente a gênese e a construção de uma proposta poética intitulada pelo próprio artista de arte-soma. Para tanto, prioriza-se o período que vai do início de sua carreira como romancista até a realização de seu primeiro filme, Hitler $I I^{\circ}$ Mundo (1968), considerado aqui peça central na realização desta poética.

\section{Palavras-chave:}

1 - Arte - história e crítica; 2 - Cinema brasileiro; 3 - Cinema - teoria e crítica; 4 - Estética; 5 - Romance brasileiro - século XX; 6 - Paula. José Agrippino de 


\begin{abstract}
This work accompanies the artistic trajectory of the writer, playwright and filmmaker José Agrippino de Paula from the launch of his first novel, Lugar Público, in 1965, to some of his experiences with films super-8 already in the 1970's. As a fundamental axis, it reports the genesis and the construction of a poetical proposal entitled by the artist himself as arte-soma. It focus the period of the beggining of his career as a novelist until the completion of his first film, Hitler III ${ }^{o}$ Mundo (1968), considered here the central piece on the realization of this poetics.
\end{abstract}

\title{
Word-keys:
}

1 - Arts - history and criticism; 2 - Brazilian Cinema; 3 - Movie Critiscism; 4 - Aestethics; 5 - Brazilian Novel; 6 - Paula, José Agrippino de 


\section{Índice}

Apresentação .... Pág. 9

Parte 1 - Lugar Público (1965) e Panamérica (1967)

I . Pág. 14

II Pág. 36

III Pág. 55

Parte 2 - Hitler III $^{\circ}$ Mundo (1968)

Tomo Pág. 86

Conclusão: "Além do Rito"

Tomo Pág. 147

Bibliografia Pág. 157

Filmografia de José Agrippino Pág. 163

Espetáculos do Sonda Pág. 164 


\section{Apresentação}

Poderia ter sido simplesmente mais uma dessas sessões especiais para cinéfilos, com gosto de Cinemateca, mas não foi. O público típico do centro da cidade, composto por toda sorte de ocioso capaz de estar numa sala de cinema às 15 hs de uma Quinta-feira (incluindo entre estes os estudantes como eu), acabou comparecendo a Galeria Olido em número considerável, menos, é lógico, pelos atrativos do programa, uma retrospectiva do assim chamado Cinema Marginal, e mais pela sedução irresistível do ingresso gratuito. Eis que tivemos então uma verdadeira "sessão de cinema", tripla: primeiro o curta Blá, Blá, Blá de Andrea Tonacci seguido pelo (quase) longa Hitler $I I I^{\circ}$ Mundo de José Agrippino e, por fim, o já então clássico O Bandido da Luz Vermelha de Rogério Sganzerla. Agrippino falecera ainda há pouco e a sessão não deixava assim de revestir-se com o verniz de uma homenagem póstuma oficial já que o antigo Cine Olido - encravado na Avenida São João bem ao lado do Teatro Municipal, respirando assim esse ar permeado pelos dejetos das utopias modernistas - pertencia agora ao departamento de cultura da Prefeitura Municipal. Corria o ano vivido de 2007.

Desde o primeiro momento, ao contrário do polido público de mostras e festivais, a massa da Olido se manifestou sem pudores: vaiava e xingava alto os filmes, especialmente a fita de Agrippino. Fiquei perplexo, mas não muito, ao notar que um filme considerado um marco do cinema experimental brasileiro como O Bandido da Luz Vermelha mantinha intacta sua conexão profunda com o imaginário dos cinemas do centro enquanto Hitler III ${ }^{o}$ Mundo, quarenta anos depois de produzido, ainda causava a mesma rejeição enfurecida. Um sujeito na fileira atrás de mim repetia sem parar: "cinema brasileiro não tem jeito, é um lixo". Tive a sensação de que os filmes que ali eu via tinham, pelo menos por um instante, finalmente reencontrado seu público. 
Obviamente que certas coisas haviam mudado: nossa longa trajetória cinematográfica no subdesenvolvimento havia tido sua noite negra (a "década perdida"; o período Collor) e também sua retomada (com alguns sucessos), acompanhando assim como a própria economia do país, mas a verdade é que o povo ainda estava lá, com camisas novas, mas estava. E importante: os filmes também estavam. Fabulei imediatamente uma questão: por quê o público recebia $O$ Bandido com agrado e ralhava contra Hitler? Decerto que algumas respostas me pareciam evidentes (perto do filme de Sganzerla, a obra de Agrippino não passava de um experimento amador), mas outras nem tanto. Foi o embrião para o surgimento deste trabalho.

Ele nasceu como um estudo comparativo entre o filme de Sganzerla e a película de Agrippino. Rapidamente, no entanto, um problema se apresentou: enquanto uma considerável fortuna crítica já se acumulava sobre os filmes do primeiro, quase nada havia sido escrito sobre o segundo. Pois bem, se isso por um lado dificultava a realização de um trabalho acadêmico, por outro despertava aquela excitação intelectual que só as searas pouco exploradas reservam aos viajantes. Logo nas primeiras conversas com o professor Ismail, orientador desta dissertação, já ficou claro que o trabalho deveria ser exclusivamente sobre Agrippino. Esta ideia foi ganhando ainda mais corpo a partir de uma intuição muito forte que tive ao ver no cinema, naquela sessão, Hitler III $^{o}$ Mundo. Tive a impressão de que havia gostado do filme pelo fato de ter reconhecido nele os temas que já havia encontrado em seu livro Panamérica. Argumentando com um amigo, na saída do cinema, cheguei a sugerir que só "aproveitaria" o filme aquele que conhecesse a obra anterior do escritor paulista. Esta percepção muito forte me deu a certeza de que qualquer trabalho sobre Hitler III $^{\circ}$ Mundo deveria ser capaz de integrar a literatura de Agrippino.

Diferente de Sganzerla, Agrippino não era um realizador de filmes, um homem de cinema, mas tinha outras origens. Seu trabalho como literato prolongava-se no teatro e Hitler $I I I^{o}$ Mundo era nesse sentido menos um filme de autor, inscrito na trilha aberta pela Revisão Crítica do Cinema Brasileiro de Glauber Rocha, e mais um experimento conduzido por um grupo teatral: o Sonda. Era necessário enxergar as experiências de Agrippino nos mais diversos meios como uma 
prática unificada (e ao mesmo tempo plural), um conjunto de intervenções no cenário artístico que configurava menos um apanhado de obras independentes e mais uma postura, uma intervenção, algo próximo da maneira como muitos artistas conceituais "contemporâneos" entendiam sua produção. Enquanto o Bandido de Sganzerla, como rebento maior do Cinema Marginal, se legitimava dentro de nossa filmografia a partir de um confronto direto com o Cinema Novo, Agrippino abria já pequenas ranhuras nessa filmografia ao afirmar-se como um marginal entre os marginais. ${ }^{l}$

Abandonando assim Sganzerla (mas não em espírito), me faltava ainda uma chave, uma "idéia força" que me possibilitasse sondar de modo mais profundo as realizações de Agrippino. Esta idéia me foi proporcionada pelo próprio autor. No programa do espetáculo Rito do Amor Selvagem, a mais famosa e mais importante realização do grupo Sonda, escreve ele:

\begin{abstract}
"O processo de trabalho do SONDA poderia ser chamado de mixagem (...) os vários componentes heterogêneos: cenários, elementos de cena, texto, som, podem correr paralelamente em linhas independentes formando montagens simultâneas de significado que resultam na artesoma (...) O objetivo coletivo nasce livremente e contém em si todas as manifestações coletivas que historicamente estão integradas em nós: o show, a dança, o teatro, o circo, o happening, o cinema, os rituais, nas suas formas mais arcaicas, primitivas e contemporâneas."2
\end{abstract}

Caracterizando sua peça como uma arte-soma (o grifo no texto é meu), Agrippino me permitiu investigar sua obra sob a luz desta denominação programática que me pareceu das mais instigantes. É o que eu faço neste trabalho que aqui se apresenta. Ele se divide em dois capítulos básicos. O primeiro deles contém uma leitura crítica, em três partes, dos dois "romances" do escritor paulista, Lugar Público (1965) e Panamérica (1967), sendo a tese fundamental da argumentação algo bem simples: ambos os livros já são parte, em maior ou menor grau, do projeto de Agrippino de realizar uma arte-soma. O segundo capítulo, por sua vez, é inteiramente dedicado a Hitler III ${ }^{\circ}$ Mundo, privilegiando uma análise desse filme como fruto inextrincável das pesquisas de linguagem relacionadas ao grupo teatral Sonda, onde Agrippino dividia a criação com sua parceira de

1 Vale lembrar que a primeira exibição pública "oficial” (com documentação registrada) do filme somente acontecerá numa mostra retrospectiva do Cinema Marginal realizada pelo Centro Cultural São Paulo em 1984, portanto, mais de quinze anos depois da produção do filme.

2 Programa reproduzido na publicação do Centro de Estudos em Arte Contemporânea de São Paulo intitulada Arte em Revista $n^{\circ} 5$ (Maio de 1981) - p. 97. 
arte e de vida, a bailarina e coreógrafa Maria Esther Stockler. Por fim, uma conclusão que nos remete ao espetáculo total Rito do Amor Selvagem, ponto culminante do projeto desta arte-soma. Essa conclusão espia também de modo breve alguns desdobramentos posteriores da dupla, dedicando alguma reflexão sobre a produção do casal nos anos setenta em filmes Super-8, especialmente Céu Sobre Água (1978).

Decerto que as experiências de Agrippino e sua arte-soma são próprias da época em que foram produzidas (os anos 60) e partilham com o cenário internacional, seja das artes, seja da filosofia de um modo geral, um grande conjunto de questões (e propostas). Essas influências e confluências serão apontadas sempre que for necessário, mas é preciso destacar que o mais importante para este estudo é um contato direto com as obras, uma análise das suas características formais e suas implicações no plano da significação. Com isso, ressalta-se a trajetória intrínseca e interdependente dessas obras na constituição de uma poética particular, mesmo quando estas se apresentam em íntima relação com a vivência das transformações radicais pelas quais passou o país naquele período. A vontade que move esta pesquisa é a de descobrir e propor idéias sobre um apanhado de experimentos dos mais significativos no panorama das artes brasileiras dos últimos cinquenta anos. Esta pesquisa almeja, portanto, contribuir para que um número maior de pessoas tenha interesse pelos trabalhos aqui comentados e, se possível, almeja também prolongar criticamente a experiência daquelas obras nos leitores que aqui se arriscarem.

No mais, espero que as limitações patentes em transitar pelas bibliografias de diferentes esferas (literatura, teatro, cinema, filosofia) possa ser entendida como um esforço em melhor compreender uma experiência estética que julgou necessária a intercambialidade de meios, técnicas e processos justamente no momento em que as "grandes narrativas" de explicação do mundo entravam em crise. A arte-soma requer uma crítica de interferências, nem sempre livre do comentário fugaz e diletante. Mas isso de modo algum significa uma decréscimo de rigor, pelo contrário, a especialização é uma exigência burocrática, não necessariamente do saber. Deixo que a soma dos meus erros me revele o pensamento sempre (re)nascendo diante da obra. 
Lugar Público (1965) e Panamérica (1967) 
Lugar Público é o romance de estreia de José Agrippino de Paula publicado em

1965 pela Civilização Brasileira e só relançado numa segunda edição trinta e nove anos depois. Tamanho abismo entre as duas edições é a principal causa responsável pelo completo silêncio da bibliografia crítica a respeito do livro, mesmo daquela mais interessada na literatura dita marginal ou experimental - mas não é a única. A trajetória "clínica" deste artista (seu diagnóstico como esquizofrênico), além da sua transformação ao longo dos anos numa espécie de figura folclórica da contracultura brasileira, o bruxo de Embu das Artes, lançaram certa fantasmagoria sobre seus trabalhos, privando-os de uma análise mais minuciosa. Some-se a isso as dificuldades que a proposta estética de Agrippino oferece a crítica, obrigando-a a transpor continuamente as esferas restritas de suas especialidades, e teremos uma ideia das razões pelas quais esta obra, entre outras de Agrippino, permanece oculta em meio a sua própria legenda.

Como realização de um autor estreante, Lugar Público é um livro marcado por um forte tom autobiográfico, com aquela comiseração juvenil de quem ainda não conseguiu vislumbrar a criação artística para além do seu universo pessoal de referências. É preciso, no entanto, reconhecer logo de início que há igualmente uma alta dose de efeito planejado nessa autoreferencialidade. A modernidade literária parece ter conduzido o escritor cada vez mais para a projeção explícita de sua subjetividade, na qual ele deveria buscar uma relação imanente com as esferas discursivas, com a língua. Para Agrippino, isso significou a possibilidade de uma literatura brasileira distante da tipologia social do regionalismo e do romance de costumes, talvez as duas grandes tradições de nosso romance que revivesciam, em nova chave, de modo intenso e criativo no começo da década de sessenta - só que grippino queria outra coisa, algo que cheirasse mais a dura 
poesia concreta das esquinas paulistanas. Daí este seu primeiro trabalho afinar-se com parte das experiências então mais recentes da prosa européia, especialmente as de língua francesa, que Jean Paul Sartre na introdução à primeira edição de Retrato de um Desconhecido (1948) de Natalie Sarraute chamou de "anti-romances" modernos, frutos como eram de uma "consciência pesada" de definição imprecisa, "vivos e vigorosos" embora "completamente negativos", onde a autenticidade, ainda que sugerida pelo relato, permanecia sempre invisível ${ }^{3}$. Ao mesmo tempo, ele procurou se desvencilhar de certo vício do velho mundo europeu em considerar a história como um longo declínio dos seus melhores dias, abrindo-se para as vanguardas anti-teleológicas ${ }^{4}$ do Novo Mundo e apelando para essa vontade de enxergar um futuro nacional até então impensado. Fecundava-se assim o embrião de uma obra híbrida, para além do novo e do velho.

Não seria de todo mal, portanto, caracterizar de início Lugar Público como um romance expressivo à maneira de Sursis do próprio Sartre: biográfico, sim, mas de um modo que dispense o sujeito-narrador unificado sendo, antes de tudo, incompatível com este. Essa insubstancialidade do narrador é logo facilmente detectável na autonomia primária dos parágrafos de $L P$, bastante independentes uns dos outros, o que nos transmite a desconfortante sensação de estarmos diante de um novo narrador a cada novo respiro, mesmo sabendo que, implicitamente, acompanhamos todo o tempo um certo (e mesmo) autor-personagem que nos conta sobre sua "inabilidade congênita para a vida" (p. 41). Também ao gosto existencialista, o enredo do livro - rascunhável dentre um emaranhado de tramas e vidas paralelas - é bastante simples e banal: separando-se da família, nosso personagem vai morar em outra cidade como estudante universitário. Ali acompanhamos suas errâncias, seu périplo sem destino por este "lugar público" ao lado de um punhado de figuras um tanto bizarras. Por fim: a formatura, a morte do pai, o retorno para casa e a indefiniç̧ão quanto ao futuro.

3 SARTRE. Préface In: SARRAUTE. Portrait d'un Inconnu - p. 7-14.

4 Andreas Huyssen, discutindo a polêmica sobre o pós-moderno, caracteriza a vanguarda americana sessentista dos happenings e da pop art como uma problematização crítica da "teleologia da arte moderna cujo subtexto latente é a ideologia da modernização". In: HUYSSEN. Mapeando o Pós-moderno - p. 42.

5 Quando as citações das obras literárias examinadas acontecerem no corpo do texto, preferi apontar a referência entre parênteses para evitar uma sobrecarga de notas de pé de página. 
"Quando se vive, nada acontece", eis o mote - é preciso narrar, tomar parte em sua própria aventura. As deambulações, a náusea permanente perante os fatos e as coisas, as digressões sentimentais sobre a inutilidade do ser, tudo remete o leitor para aquela "voga existencial" de fins dos anos 50. No entanto, como um legítimo "ultrapassamento" sartreano, Lugar Público é um romance que explora outras implicações de assertivas como "falar é agir; uma coisa nomeada não é mais inteiramente a mesma, perdeu a sua inocência"" e não parece afeito a concepção do filósofo francês que toma a linguagem como o instrumento de uma intencionalidade anterior ao ato. $\mathrm{O}$ permanente jogo de espelhamentos entre os inúmeros duplos do narrador-personagem espalhados pelo texto, como numa deriva interminável de sensações, já parece apontar em $L P$ para os limites de uma concepção do sujeito como consciência reflexionante. Estamos aqui em plena "era da suspeita"8 onde uma nova sensibilidade para a literatura deveria partir das ruínas de antigas vigas mestras do humanismo como a psicologia (a personagem definida em suas ações através de uma fundamentação psicológica) e a temporalidade (a construção de um tempo organizado das ações, geralmente linear, compatível com o desenvolvimento psicológico das personagens e da história).

Assim, esse "novo romance urbano" de Agrippino tampouco tem muito em comum com aquela outra linhagem já consolidada de romances brasileiros que tomaram como matéria bruta de seu universo ficcional nosso processo crescente de urbanização. Como exemplos, citaria $O$ Amanuense Belmiro de Cyro dos Anjos, Os Ratos de Dyonélio Machado e Angústia de Graciliano Ramos, cujo vínculo mais flagrante talvez seja a representação dessa "figura do fracassado", que de arquétipo maior da literatura da primeira metade do século XX - o homem desfibrado, sem qualidades, entregue a dissolução das práticas e costumes - ganhou novos tons no Brasil dos anos 30 e 40, sendo aqui a encarnação em outras roupas daquele nosso velho e conhecido mal-estar: o impasse entre duas formações sociais distintas (uma progressista, outra arcaizante) que insistem em coexistir promiscuamente em nossas instituições. ${ }^{9}$ Distintamente destas obras, que ainda mantinham certa

6 SARTRE. A Náusea - p. 66.

7 SARTRE. Que é a Literatura - p. 20.

8 SERRAUTE. L'ère du Soupçon. In: L'ère du soupçon: essays sur le roman.

9 GIL. O Romance da Urbanização - cap. 1 e 2. 
distância crítica da Modernização através de uma reestruturação, sob o signo do Modernismo, daqueles aspectos essenciais do "realismo formal" próprio do romance burguês ${ }^{10}$, Lugar Público parece mais interessado numa escrita da transparência impossível, da separação consumada entre as palavras, as coisas e as pessoas. É nesse sentido que o livro de Agrippino tem um precedente ilustre em nossa literatura:

"E o dia em que chorei? - havia certo desejo de mentir também estudava matemática e subitamente senti a impossibilidade tremenda e fria do milagre. Olho por essa janela e a única verdade, a verdade que eu não poderia dizer àquele homem, abordando-o, sem que ele fugisse de mim, a única verdade é que eu vivo. Sinceramente, eu vivo. Quem sou? Bom, isso já é demais." $" 11$

Joana, adolescente numa tarde qualquer, descobre, no meio de uma lição de matemática, a impossibilidade do milagre, ou ainda: descobre que o único milagre possível é não haver milagre algum. Ela é a víbora (p. 194): diante da morte do pai, da mesquinhez burguesa dos tios, das traições do marido e da gravidez de sua amante, da ameaça de um estranho que a persegue pelas ruas, ela se mostra verdadeiramente interessada apenas por esse estado de promiscuidade em que se vive com as velhas palavras, aquelas que acabam por ocupar-lhe todo o espaço mental: "ando sobre trilhos invisíveis. Prisão, liberdade. São essas palavras que me ocorrem. No entanto, não são palavras verdadeiras, únicas e insubstituíveis, sinto-o. Liberdade é pouco. O que desejo ainda não tem nome" (p. 82). Sua filosofia é a revolta, em contraste com o bacharelismo de Otávio, o marido. Se Joana inveja por instantes "aquele ser meio morto", a tal matrona da qual pretende alugar uma casa, é pela única razão desta "compreender a vida porque não é suficientemente inteligente para não compreendê-la"(p. 90). Sua escolha última é viver, já que a morte é outra coisa. Ela fracassa perante as obrigações sociais de filha, esposa e amiga porque seu ímpeto é matar para florescer, como lhe diz o Professor, e seu objetivo maior é a "desvalorização do humano" (p. 107). Nisso, sua expiação contra

10 WATT. Ascensão do Romance. O "realismo formal" é este "relato completo e autêntico da experiência humana que, portanto, tem a obrigação de fornecer ao leitor detalhes da sua história como a individualidade dos agentes envolvidos, os particulares da época e dos locais de suas ações - detalhes que são apresentados através de um emprego da linguagem muito mais referencial do que é comum em outras formas literárias” (p. 31).

11 LISPECTOR. Perto do Coração Selvagem - p. 28. 
as "velhas palavras" se imiscui na ânsia de seu duplo maior: Clarice Lispector.

"Sim, eu sei, continuava Joana. A distância que separa os sentimentos das palavras. Já pensei nisso. E o mais curioso é que no momento em que tento falar não só não exprimo o que sinto como o que sinto se transforma lentamente no que eu digo. $\mathrm{Ou}$ pelo menos o que me faz agir não é, seguramente, o que eu sinto mas o que eu digo." 12

O que encontramos aqui é uma escritora pensando efetivamente a matéria verbal de sua obra, coisa até então incomum em nossa tradição literária e justamente aquilo que o crítico vaticinava como necessário para que nossos romances atingissem a maturidade artística: "para que a literatura brasileira se torne grande, é preciso que o pensamento afine a língua e a língua sugira o pensamento por ela afinado. Uma corrente dupla, de que saem as obras-primas e sem a qual dificilmente se chega a uma visão profunda e vasta dentro da literatura"13. Não é de se espantar, portanto, que o mesmo crítico afirme seu estado de "verdadeiro choque" ao deparar-se com o primeiro romance da jovem Clarice; nem estranhemos o deslumbramento de um outro conhecido comentador ressaltando a dimensão existencial do livro:

\begin{abstract}
“A obra de Clarice Lispector surge no nosso mundo literário como a mais séria tentativa de romance introspectivo. Pela primeira vez um autor nacional vai além, nesse campo quase virgem de nossa literatura, da simples aproximação: pela primeira vez um autor penetra até o fundo da complexidade psicológica da alma moderna, alcança em cheio o problema intelectual, vira no avesso, sem piedade nem concessões, uma vida eriçada de recalques". ${ }^{14}$
\end{abstract}

Podemos dizer como Wilson Martins, descontados os exageros rebarbativos próprios ao autor e sua implicância com aquilo que chamava de "romance nordestino", que Perto do Coração Selvagem (1944) marca um ponto de ruptura e "inicia uma nova idade das letras brasileiras. Não somente novos temas e novas técnicas narrativas, mas também, e sobretudo, um novo estilo e uma nova visão de mundo". ${ }^{15}$ Não se trata, evidentemente, do primeiro romance que "procura estender o

12 LISPECTOR. Opus Cit. - p. 109

13 CÂNDIDO. Uma Tentativa de Renovação. In: Brigada Ligeira - p. 88.

14 MILLIET. Diário Crítico v. II - p. 32

15 MARTINS. História da Inteligência Brasileira, v. VII- p. 212. 
domínio das palavras sobre regiões mais complexas e mais inexprimíveis"16, muito menos de uma novidade exclusivamente no que diz respeito a fragmentação da narrativa e da sintaxe, todos sabemos que os modernistas da geração de 22 já haviam produzido obras com essas características. A questão aqui diz respeito à tessitura particular das muitas tramas que compõe a figura de Joana, pois esta, nas palavras de outro crítico, não nos mostra "a ligação dos fenômenos psíquicos entre si”, assim como não fornece ao leitor a "sua ligação ao nível organizado e configurado". Ou seja, "os momentos psicológicos, construídos cada qual a partir dos seus elementos mínimos, não podem se inserir num desenvolvimento de cunho histórico e não podem constituir, portanto, uma biografia". ${ }^{17}$

É isso o que distingue o livro de Clarice, por exemplo, da prosa de invenção oswaldiana, de ordem memorialística, mesmo partilhando com esta o interesse por uma renovação estilística do romance, esse gênero maior da arte burguesa da escrevinhação. Enquanto Serafim Ponte Grande e Macunaíma são, bem ou mal, heróis da nossa gente, Joana nos permanece um claro enigma, o lugar mesmo onde o mundo empírico perde toda a solidez. Num breve exercício de leitura, poderíamos dizer que a aspiração maior dos Andrades nos remete ao desejo de fazer um livro que seja uma antologia de si mesmo ${ }^{18}$, o antilivro definitivo. No pequeno opúsculo de Clarice, menos que essa confiança numa invocação babélica e ilimitada da criação verbal, a questão é a possibilidade do sujeito aceitar os objetos a sua volta como tais, na sua austeridade material e imanente, no lapso do sentido, onde “o espírito, perdido no labirinto da memória e da auto-análise, reclama um novo equilíbrio. Que se fará pela recuperação do objeto. Não mais na esfera convencional do algo-queexiste-para-o-eu (nível psicológico), mas na esfera da sua própria e irredutível realidade." ${ }^{19}$ Daí talvez a impressão de Antônio Cândido de que o livro de Lispector, com sua escrita um tanto monótona, seria um precursor desconhecido do nouveau roman francês e provavelmente "a origem das tendências desestruturantes, que dissolvem o enredo na descrição e praticam esta com o gosto pelos

16 CÂNDIDO. Idem - p. 88.

17 SCHWARZ. Perto do Coração Selvagem in: A Sereia e o Desconfiado. - p. 55.

18 CAMPOS. Serafim: um grande não livro. In: ANDRADE. Serafim Ponte Grande - p. 8.

19 BOSI. História Concisa da Literatura Brasileira - p. 476 
contornos fugidios." 20

A matéria de onde o autor de Lugar Público extrai a força de sua criação, essa ânsia por uma unidade que desfalece perante a irredutibilidade do mundo a um princípio racional, já está presente em Perto do Coração Selvagem que, no mais, espia de perto esse "confronto perpétuo do homem com sua própria obscuridade"21, descrito por Albert Camus como a única verdade desses novos tempos - o absurdo. O romance introspectivo de Clarice, falando apenas em seu próprio nome, dispensa a alegoria social, a análise psicologizante e o preciosismo descritivo para, através da palidez ruidosa de suas frases, desnudar a crise das transcendências penetrando num universo de alienação explicitamente desejado onde o sujeito-narrador, para além de restringir-se em ser a consciência infeliz da sociedade, aspira a permanente dissolução de si mesmo.

Em Lugar Público, essa aspiração se compraz numa espécie de hesitação da escritura. Logo num dos primeiros trechos do livro, dois homens caminham por uma avenida discutindo sobre "aquele algo fundamental" que os unia, mas que eles não sabiam o que era, tendo a certeza, no entanto, de que era algo negativo (p. 29-30); um pouco mais adiante, noutro parágrafo, três homens fazem refeições num restaurante de baixo preço enquanto refletem sobre o "caráter essencial" da ligação entre eles, concluindo que este não existe, restando-lhes apenas um "paralelo de vida horizontal” (p. 41-2); mais quinze páginas a frente e desaguamos num diálogo enfarpado, em forma dramática, entre Ele e Ele Mesmo (p. 57). Em todos os casos são duplos conversando entre si, estilhaçando a partir de sua incompreensão fundante o sopro divino da personalidade e, consequentemente, a "voz de Deus" da narrativa. O expediente poético mais característico desta experiência é a utilização bastante livre dos pronomes pessoais: Agrippino faz questão de narrar sua história ora em primeira pessoa, usando o pronome "Eu", ora preferindo nomeá-lo na terceira pessoa, num "Ele" que surge a todo instante como um outro.

Mesmo levando em conta que no universo ficcional, por não possuirmos a materialidade física da terceira pessoa (temos apenas a $1^{\mathrm{a}}$, o autor e a $2^{\mathrm{a}}$, o leitor), o uso dos pronomes 
pessoais perde muito da rigidez do uso cotidiano, vale uma investigação sobre a utilização desses pronomes. Em primeiro lugar, este personagem-narrador que busca escrever-se, no sentido da aventura de Roquentin, precisa tornar-se, para tanto, um leitor, uma testemunha de si mesmo, nesse caso, o "Ele" soa mesmo como uma terceira pessoa com função de primeira. Poeticamente, "esse emprego faz com que a pessoa a quem nos dirigimos seja incluída na história na categoria das personalidades públicas cujos feitos e gestos qualquer um deveria conhecer”, escreveu Michel Butor. ${ }^{22}$ É o famoso caso do "Ele" utilizado por César em seus Comentários. Dado o interesse de Agrippino pelo sentido grandiloquente, "épico" da História, em contraste com esta dimensão banal e cotidiana da narração romanesca, este artifício contempla aquela dialética criadora típica da modernidade artística: mito $\mathrm{x}$ história, alta cultura $\mathrm{x}$ baixa cultura, tradição $\mathrm{x}$ novo, mas já sinalizando, e isso é o fundamental, para uma inversão instrumental dos padrões estéticos estabelecidos onde uma obra de arte só poderia ser Vanguarda se fosse capaz de romper em suas invenções formais com uma lógica do efeito, do entretenimento, do prazer imediato e comercial típica do Kitsch ${ }^{23}$. De modo que em Lugar Público "é a cultura de vanguarda que, reagindo contra a situação maciça e envolvente da cultura de massas, toma emprestado do kitsch os seus estilemas" ${ }^{24}$, conforme vaticinou Umberto Eco à mesma época em que o livro de Agrippino era publicado. Num rápido esboço de diagnóstico cultural, diríamos que o kitsch, antes a própria expressão da má consciência em estética, esse desequilíbrio ontológico entre os elementos e sua função, de face utilitária e vulgar, acaba tomando de assalto a cena artística dos anos 50 e 60 como o retorno do recalcado, o ponto cego no projeto modernista.

Mas há também uma outra função, latente, neste expediente formal da troca de pronomes, função de importantes consequências epistemológicas: na medida em que "cada vez que se quiser descrever um verdadeiro progresso da consciência, o próprio nascimento da linguagem, é a segunda pessoa que será a mais eficaz", ${ }^{25}$ justamente aquela que caracteriza o eu como um outro, o que encontramos na narrativa agrippiniana é essa projeção do mundo de maneira indireta e subjetiva,

22 BUTOR. O uso dos pronomes pessoais nos romances in: Repertório - p. 53.

23 GREENBERG. Vanguarda e Kitsch (ver bibliografia).

24 ECO. A Estrutura do Mau Gosto. In: Apocalípticos e Integrados - p. 127.

25 BUTOR. Idem - p. 52 
uma meditação sobre esta fé moderna no fracasso do "eu” em buscar o outro. É preciso, no mais, crer neste fracasso, olhar por ele. O que nos resta então é aquele "grau zero" onde o sentido é sempre um porvir: a função do escritor é combater a Literatura. Agrippino parece combinar, no mesmo recurso formal, a crise da consciência européia com a irrupção do novo (mau) gosto americano sem perder a colaboração milionária de todos os erros do imaginário subdesenvolvido. Vejamos este trecho:

\begin{abstract}
"Ele caminhava por uma rua. A multidão cruzava em todos os sentidos; a rua era estreita e os ônibus, homens, mulheres, velhos e crianças, apertavam-se entre os edifícios. Ele percebeu um gesto, o gesto de uma velha que inclinou penosamente o corpo para baixo e resmungou para a outra mulher. Uma tira de chinelo havia arrebentado. A velha pretendia consertar o chinelo ali mesmo, na rua, onde todos passavam. Continuou resmungando e encostou-se à parede, e retirou o chinelo do pé.

Ele tinha feito um roubo perfeito. Nada estava errado. Mas a polícia descobriu, não por habilidade própria, mas por simples acaso. A descoberta não destruía o seu valor. Da parte dele não poderia existir reprovação, tudo estava perfeito. Ele teve pouca sorte, Os dois policiais mal-encarados e enormes se aproximavam para prendê-lo. A jovem que o acompanhava disse: 'você tem que fugir'. Ele continuou olhando o chão, encolheu os ombros e disse: What's the difference?"26
\end{abstract}

Despido de suas funções essenciais de narrador confiável e personagem com desenvolvimento psicológico, este "eu" da escritura pode experimentar muitos "outros" possíveis numa fantasia de criação infinita. No primeiro parágrafo temos uma situação prototípica da sensibilidade moderna: em meio a confusão generalizada da metrópole, a percepção se fixa subitamente numa cena efêmera e absolutamente banal - o gesto de uma velha mulher que se inclina para consertar o chinelo arrebentado. Eis todo o frescor fenomenológico, o heroísmo da vida moderna de inspiração baudelairiana: transpirar uma arte que conte o clima do dia, desta ou daquela rua, onde o artista deve ser capaz de épouser la foule, de adentrar "a multidão como se esta fosse um imenso reservatório de energia elétrica", assim podendo "expressar ao mesmo tempo a atitude e os gestos dos seres, solenes ou grotescos, e sua luminosa explosão no espaço" ${ }^{27}$ Só que um século e tanto depois de Baudelaire, a luminosa explosão da "passante" do poeta francês acabou pastichizada pelo provincianismo suburbano desta cena onde uma velha de carnes abundantes abaixa-se com tremenda dificuldade, no meio de uma conversa de rua, para apanhar seu chinelo arrebentado, um signo de 
classe apanhado pelo poeta em todo o seu "mau gosto", despido de qualquer sensibilidade ou simpatia brejeira - uma cena que poderíamos muito bem classificar de kitsch. O causo é que esse dito "mau gosto", entre nós, seres do Terceiro Mundo, torna-se a prova dos nove de uma nova estética marginal, bárbara, pulsante, vislumbrada nos escritos de Oswald de Andrade. A cena da velha suburbana e macilenta ajeitando seu chinelo barato no seio da metrópole de alto edifícios e carros velozes funciona como um retrato de nossa modernidade atravancada. A escritura moderna aqui visita seu grande “duplo" reprimido, sujo, selvagem. Mais para o fim da década de 60, com a explosão da voga tropicalista, essa inconstância arcaíco-progressista da alma brasileira será o cordeiro a ser ritualmente canibalizado pelas artes. Mas voltemos a análise do trecho em questão.

No segundo parágrafo, a narrativa desloca-se de súbito para um assalto, não um assalto qualquer, mas um daqueles "de cinema". O narrador-personagem, transfigurado neste magnífico "Ele" capaz das mais incríveis encarnações, compartilha com o leitor sua "aventura" semiológica pelo mundo espetacular dos grandes criminosos. A cena corre lépida para o grande desfecho: a mocinha implora ao herói para que este fuja, mas Ele responde, impávido, estilo James Bond, numa dicção anglófila de fazer tremer o leitor-espectador: "what's the difference"? Esta segunda cena desponta feito um ruído na composição do romance, uma intermissão, como um trailer que subitamente aparece no meio do filme. Este procedimento, muito comum em todo o livro de Agrippino, nos remete menos as elipses violentas da literatura moderna, notáveis nos grandes romances de Faulkner, e mais a um "efeito zapping", uma decupagem televisiva como se ao narrador fosse sempre possível "dessintonizar" a narrativa (re)transmitindo-a em seguida através de outro “canal". De fato, o modernismo literário buscou despejar nas páginas do romance aquela violência poética que encontrava nos periódicos baratos e nos cartazes publicitários, mas algumas décadas depois destas primeiras empreitadas, os olhos e bocas dos objetos de consumo tornaram-se de tal forma onipresentes que agora é o flanêur quem é espreitado pelas vitrinas, numa espécie de epifania religiosa da mercadoria: "Um medo, um pavor. Eu estava caminhando pela avenida, parei em frente à vitrina: sutiã, saia, fitas, blusas, manequins... Eu estou esperando um milagre. Vai acontecer aqui. O 
Cristo desce e abençoa esse putos. Eu, eu vou para o céu de helicóptero" (p. 113). Se acaso olhares profundamente as mercadorias, elas olharão de volta para você, como o abismo fez com Zaratustra.

Deste abismo entre os dois parágrafos o que se destaca justamente é este “entre". Num romance que privilegia a fragmentação radical, esse abismo exterior ao todo da narrativa irrompe a qualquer instante pelos interstícios da escrita. É o triunfo da antilinguagem, onde o mundo vive por procuração nos entreatos das formas literárias, neste percurso que vai do Realismo à realidade. As descrições romanescas, seja dos personagens, seja dos objetos em volta, não dizem mais respeito objetivamente a esses, mas apenas ao próprio ato de descrever. É o buraco no centro do “ser", diriam os heideggerianos, justamente o que nos permite espiá-lo. Entende-se daí o interesse da crítica e da filosofia continental a respeito das "fissuras", das "repetições", do "entre", do "obtuso", da “diferença" - ele nasce em íntima relação com as propostas perpetradas pelos escritores, pelos novos romancistas, em sua ânsia de exprimir as novas relações na modernidade tardia entre os homens e o mundo.

Pois assim como é possível acompanharmos a trajetória disjuntiva deste eunarrador de Lugar Público, verificamos da mesma forma uma diluição completa dos personagens do romance, cujas páginas estão repletas de figuras igualmente cansadas de tantas coerências. Esses personagens geralmente aparecem "mastigados" por meio de reduções categóricas, são rabiscos cujos traços físicos e psicológicos mínimos parecem-nos nebulosos e cujas ações são descritas de maneira displicente. Um caso flagrante: essas várias figuras femininas com as quais o narrador-personagem mantém relações, figuras que chamam a atenção pela semelhança fonética de seus nomes: Lili, Lena, Lila, Lisa e Nina. Desconfiamos então de que se trata da mesma garota sob distintas "aparições", mas há sempre um novo elemento na narrativa para embaralhar essa percepção unívoca. Claro é que muitos traços gerais de tais personagens são intercambiáveis, inclusive um aborto que constantemente preocupa o narrador-personagem e que hora é atribuído a Nina (p. 95) para algumas páginas depois passar a conta de Lisa (p. 113), conduzindo o leitor-crítico para a conclusão de que a característica fundamental dessas figuras é que elas são indecidíveis - são diferenças estritas, repetições múltiplas, 
acontecimentos sem origem. Uma mulher não é uma mulher, é o conjunto irredutível de suas versões.

O mesmo acontece com seus "amigos", todos batizados com nomes de celebridades históricas. De início, pensei ser possível atribuir a alguns deles traços mínimos de caráter: Dario seria o comunista, Pio XII um tipo bêbado e boêmio, Napoleão um escritor e funcionário público, Cícero um homem casado e dependente da mulher, mas ao longo da narrativa percebi que este esforço era um tanto inútil, pois embora uma ou outra característica básica pudesse sim ser reconhecida, o mais óbvio era que muitas outras, incluindo certos feitos e ações, eram totalmente intercambiáveis. Isso nos conduz as tais perguntas: será esse personagem sempre o mesmo? E sendo ele o mesmo, será sempre idêntico a si? ${ }^{28} \mathrm{O}$ esquema de Lugar Público privilegia a transformação desses personagens em significantes puros e o fato de seus nomes remeterem a grandes figuras históricas perfaz um processo paradoxal de (des)mitologização dos mitos, na medida em que essa fala que transforma conhecidos signos da língua (e da tradição) em novos significantes é o que caracteriza, semiologicamente, o mito. ${ }^{29} \mathrm{Na}$ época da cultura de massas, cabe a cada um forjar sua própria mitologia.

Tal mitologia choca-se, evidentemente, com a representação da história. Mesmo nas muitas vezes em que esta parece aportar no romance, como nos trechos sobre confrontos políticos nas ruas, sobre o golpe de 64 e a atmosfera de exceção, as contradições particulares a historicidade dos fatos são substituídas por uma espacialização dos conflitos: trata-se sempre deste Lugar Público, dessa 'psicocartografia', por onde rondam esses espectros da história universal:

\footnotetext{
"Pio XII prosseguia dizendo que o único caminho verdadeiro é virar a lata de pedras, vira a lata de pedras, diz Pio XII; o barulho produzido pelas pedras é a história, e a mudança da posição das pedras é a história. Prosseguiu César dizendo que o século XX pretende movimentar muito a lata de pedras; mas somente isso: agitar mais rapidamente que outros séculos." ${ }^{30}$
}

Nesta espécie de "parábola das pedras que rolam” fica nítido um relativismo

28 O "enigma do mesmo" é um dos temas essenciais da filosofia da diferença e foi descrito por Jacques Derrida no seu ensaio A Palavra Soprada. O autor parte de uma citação de Blanchot onde este compara Mallarmé e Holderlin: "cada poeta diz o mesmo, e não é contudo o mesmo, é o único.” In: DERRIDA. A Escritura e a Diferença - p. 110.

29 BARTHES. O Mito como Sistema Semiológico. In: Mitologias - p. 201-08.

$30 L P-$ p. 81. 
histórico muito peculiar justamente por se assentar numa historização radical que não respeita nenhuma validade extra-histórica: o barulho das pedras é a história, a mudança das pedras também. Nada há alem desse som e fúria. Mas desta feita todo o processo histórico fica igualmente reduzido a uma estática última que só pode ser a superação da própria história em nome de uma sucessão de rearranjos desconexos, algo não muito distante dos ciclos civilizatórios que tanto fascinaram as germanófilas "ciências do espírito" do começo do século XX, em especial aquelas "sensibilidades enfermas" que se tornaram os grandes leitores de obras como A Decadência do Ocidente de Oswald Spengler. A consciência historicista deveria então dar lugar a novos estratos da mente humana.

De maneira geral, os modernistas consideraram que os estudos históricos forneciam a utensilagem básica para a formação daquele 'vazio esnobismo erudito' típico da tradição liberal-humanista, este se apossar do passado que Nietzsche chamou duplamente de história monumental e história antiquário, pretensa ciência pragmática capaz de destruir a força vital da vida: “O excesso de estudos históricos perturba os instintos do povo e impede o individuo assim como a totalidade de atingirem a maturidade". ${ }^{31} \mathrm{O}$ contraveneno seria um interesse pelo supra-histórico: “chamo ‘supra-históricas’ as forças que desviam o nosso olhar do transitório para aquilo que confere a existência seus caracteres de eternidade e de identidade, isto é, a arte e a religião." ${ }^{32}$ Temos aqui um desafio filosófico ao historicismo aproveitado pela arte moderna e sua exacerbação da subjetividade e da descontinuidade. É o que nos mostra Hayden White ${ }^{33}$ ao destacar a quantidade de personagens que são historiadores em romance modernos e a pouca simpatia dos escritores por eles - Roquentin incluso. Conforme a máxima de um destes escritores, talvez o maior deles: “a história é um pesadelo do qual tento despertar-me"34.

Essa ânsia por uma literatura supra-histórica foi compartilhada por uma vasta gama de nossos romances modernos, todos eles mergulhados na busca por uma "filosofia da história" que não condenasse o pais ao destino ardiloso da modernização subdesenvolvida. Em termos de uma

31 NIETZSCHE. Da Utilidade e dos Inconvenientes dos Estudos Históricos para a vida - p. 65.

32 Idem - p. 68.

33 WHITE. O Fardo da História. In: Trópicos do Discurso (ver bibliografia).

34 JOYCE. Ulisses - p. 49. 
sociologia do romance brasileiro dos anos 60 , somente como um esboço didático para fins de um quadro geral, talvez pudéssemos dividir nossa literatura romanesca moderna em dois grandes blocos distintos, orientados segundo sua filosofia (trans)histórica: um bloco progressista, com o "indianismo revisitado" de Quarup (1967) de Antônio Callado revivescendo a fleuma alencariana para enfatizar sua dimensão política como matriz de um sentimento nacional-revolucionário; outro bloco restaurador, que acabou produzindo um tipo muito particular de literatura regionalista, diversificada em sua fatura e em sua qualidade, mas que parece guardar pelo menos um aspecto em comum: certa nostalgia idílica da comunidade gerada pelo latifúndio, um tipo de "utopia restauradora" onde frente aos desarranjos causados pela escalada modernizante, julgou-se a possibilidade de "legitimar e edulcorar a igualmente efetiva, embora menos impessoal, injustiça das relações pré-capitalistas" 35 - do surrealismo sertanejo de O Coronel e o Lobisomem (1964) de José Cândido de Carvalho ao gótico mineiro de Ópera dos Mortos (1967) de Autran Dourado, uma dimensão regressiva, de conciliação das classes, deitou seu manto diáfano sobre nossa prosa.

Esses dois blocos, mesmo que ideologicamente opostos, nos revelam o quanto os escritores nacionais daqueles dias transpiravam em seus romances uma certa urgência da história, mesmo quando faziam-na recair no mito. Agrippino não poderia fugir a esses 'tempos de nó na garganta', mas sua aposta artística é distinta: ele não desenvolve propriamente uma filosofia da história em suas páginas, pelo contrário, preferiu um "corpo a corpo" com a história, só que não através dos fatos, num sentido realista ${ }^{36}$, mas sim dos "fatos" num sentido discursivo. Vejamos um parágrafo mais longo:

\footnotetext{
"Ele viu, através da janela, o povo correndo em pânico; no fundo, a praça e as árvores. Os tanques avançavam e houve um entendimento
}

35 ÁVILA. Da Urgência e da Aprendizagem. p. 288

36 Um exemplo de como o "realismo literário" lidou com questões muito semelhantes as encontradas em Lugar Público (a explosão dos mass media e de uma cultura de consumo, a atmosfera repressiva do golpe, uma juventude urbana à toa na maré alta da nova etapa do capitalismo) pode ser encontrado no romance Bebel, que a cidade comeu (1967) de Ignácio de Loyola Brandão. Nele, algumas invenções formais (certa violência tipográfica dos anúncios que pipocam na abertura de cada capítulo, cartas de fãs transcritas no corpo do enredo imitando a fala de populares), todas elas guardando um fascínio pelo pop e pelo kitsch, são "deglutidas" pelo distanciamento crítico intrínseco a narração nenhuma ranhura deve "desviar" o desenvolvimento linear do enredo. A "autoria" reforça a confiança no sujeito autônomo do conhecimento e o expediente preferido para penetrar no universo midiático da "garota propaganda" continua sendo a sondagem psicológica. 
entre a polícia e o exército. O golpe de estado fora efetivado duas ou três horas antes (...) Ele olhava a rua do sexto andar do edifício. Os tiros: tá, tá... tá. Um pequeno ruído isolado. Noite. Todos saíram em pequenos grupos. Pânico à frente. $\mathrm{O}$ relógio da torre da estrada de ferro. $\mathrm{O}$ povo queimou um carro-pipa ou brucutu. No outro dia algumas notícias. Fazia frio e os burgueses, protegidos por grossos sobretudos, subiam a rua estreita cercada de casas de pedra. Os burgueses entraram numa casa e o velho marceneiro olhou pra eles. O marceneiro lixava um cruz de madeira. Os burgueses sorriram para a câmera cinematográfica e disseram que aquela cruz devia ter o mesmo peso da cruz levada por Jesus (...) O burguês de bigode segurou um pouco a cruz e o homem da câmera filmou alguns segundos. O Papa sorria para os burgueses. O burguês de bigode sorriu para o Papa. O Papa sorriu para a câmera cinematográfica. Os burgueses sorriam para o Papa e o Papa sorriu para os burgueses. O Papa aproximou-se da cruz e o burguês de bigodes narrou que aquela cruz havia passado pelos lugares santos e turísticos da terra santa." $" 37$

Como eu havia notado anteriormente, a contradição dos fatos históricos - e trata-se explicitamente neste trecho sobre a tarde que trouxe consigo o 'golpe de estado' - adquire uma dimensão fantasmagórica diante deste Lugar sem lugares que nos é narrado: de uma paisagem de conflito social passa-se sem mais a uma marcenaria onde burgueses de casaca se divertem com uma cruz. Por outro lado, talvez paradoxal, a medida em que a crise do sujeito revela-se menos por um mergulho na consciência atormentada - o stream of consciousness do alto modernismo - e mais por esse discurso cruamente direto, a história deixa de ser a força que nos prende ao passado de uma ilusão, o pesadelo da tradição, e torna-se simplesmente uma efetividade dada que ganha em interesse justamente por ser só o que é, e não por seus significados, por sua dimensão alegórica ${ }^{38}$. A historicidade volta às páginas do romance, mas pela porta dos fundos: não é mais possível um conceito único de história, autêntico, transcendente. Em LP, já vislumbramos aquele tipo de literatura que "reinsere os contextos históricos como sendo significantes e até determinantes, mas ao fazê-lo, problematiza toda a noção de conhecimento histórico". ${ }^{39}$ Não se reconstrói aqui nenhum universo incerto a partir de uma nova objetividade sobre a ordem esfacelada - sobre o som das metralhadores

$37 L P-$ p. $169-170$.

38 O próprio Hayden White no texto supra citado sobre o fardo da história, não por acaso publicado em 1966, poucos meses depois do lançamento de $L P$, escreve: "um dos traços distintivos da literatura contemporânea é a sua convicção subjacente de que a consciência histórica será obliterada se o escritor tiver de examinar com a devida seriedade àquelas camadas da experiência humana cuja descoberta é o propósito peculiar da arte moderna". In: WHITE. O Fardo da História - p. 43

39 HUTCHEON, L. Poética do Pós-modernismo-p. 122. 
sobressai-se apenas o retumbante riso idiota do Papa. Aquilo que está caindo é aquilo mesmo que devemos derrubar.

Se a História não se apresentou a Agrippino como um pesadelo foi justamente porque o pesadelo já havia se feito história - a cultura da bomba ${ }^{40}$. Ele foi contemporâneo de outro Nietzsche, aquele lido por Foucault, e pôde então "prestar uma atenção escrupulosa à sua derrisória maldade", para enfim "saber reconhecer os acontecimentos da história, seus abalos, suas surpresas, as vacilantes vitórias, as derrotas mal digeridas que dão conta dos atavismos e das hereditariedades; da mesma forma que é preciso saber diagnosticar as doenças do corpo." ${ }^{41}$ A imagem do corpo aqui é importante, pois Agrippino vislumbrou a história como o próprio corpo do mito, da mesma forma que buscou trazer esse mito para mais perto do corpo. É nesse sentido que Agrippino pôde passar de personagens como Cícero e Napoleão, de Lugar Público, para a Marilyn Monroe e Harpo Marx em

\section{Panamérica.}

E se não há mais uma historicidade autêntica, tampouco deve haver uma concepção essencializada de tempo. No livro de Agrippino, o tempo está cindido de uma temporalidade, de um fluir, de uma duração. Vez por outra, o narrador-personagem invoca no presente do indicativo um acontecimento que imaginamos pertencer ao passado, como uma discussão na sala de estar entre seu pai e sua mãe que o obriga a trancar-se no quarto (p. 87) ou ainda quando Ele nos conta assim a sua experiência: "Ontem cheguei muito tarde em casa: cerca de uma hora da madrugada. Minha mãe estava acordada e meu irmão ouvia música. Fui dormir tarde. No outro dia acordei tarde. Desci para tomar café.” (p. 32-3). Percebemos claramente que o dia seguinte a ontem não é narrado como hoje. E se imaginarmos que no rascunho de enredo que estou propondo Ele já abandonou a casa dos pais rumo a outra cidade, este ontem nos remete há um passado muito mais longínquo que, no entanto, é vivido como um presente perpétuo - da mesma forma quando Ele nos conta sobre seu pai morto (um evento aparentemente futuro na anedota). Eis então um livro onde "o espaço destrói o tempo e o tempo sabota o espaço. A descrição não progride, contradiz-se, anda à

40 HOISEL. Supercaos: os estilhaços da cultura em Panamérica e Nações Unidas - p. 113

41 FOUCAULT, M. Nietzsche, a genealogia e a história. In: Microfísica do Poder. São Paulo, Ed. Graal, 1979 , p. 21. 
volta. O instante nega a continuidade. ${ }^{, 42}$ Em todos os aspectos temos esta descontinuidade temporal que "liberta" o leitor do "pesadelo da história": o único tempo que interessa é o tempo contido na própria escrita, o tempo do leitor que imagina em sua mente todo o enredo. Aqui desponta uma questão de estilo: Agrippino parece hesitante em levar essa experiência até a diluição completa da temporalidade subjetiva e especialmente no terço final do romance temos uma recuperação cronológica dos fatos que acabam "organizando" internamente a narrativa. Comentarei mais a respeito desta "recaída do autor" no segundo tópico deste capítulo.

Por hora, vale a observação: se não há mais o tempo pleno de sentido, o pesadelo da história do qual o poeta deve despertar, isso se deve também ao fato de que a escritura onírica de $L P$ não é a mesma da vulgata surrealista, em sua porção órfica, mas remete-se aquela de Artaud: uma escrita diurna. Nos movemos como nos sonhos, sim, vimos bem isso no trecho citado da Cruz e do Papa: num instante andamos numa rua, noutro estamos numa marcenaria - mas nessa escrita não é a razão que desce ao mundo dos sonhos para espiá-los, munida com o arsenal da linguagem analítica, mas são os sonhos, na epiderme do texto, que devem insuflar as frases; morfologicamente, a composição do livro é pálida, articialmente esquemática, para que os corpos dos objetos se projetem pelas ameias da sintaxe. "Não se trata de suprimir o discurso articulado, mas de dar as palavras a importância que elas tem nos sonhos" ${ }^{43}$, diria Artaud. As palavras devem se encher de sonhos e não serem "intérpretes” deles. Na sua polêmica com Germaine Dulac, que dirigiu 'A Concha e o Clérigo', ele acusou a diretora de ter traído o espírito do seu roteiro ao contentar-se em fazer dele um sonho narrado. ${ }^{44}$ Ora, os sonhos não devem ser entendidos em sua porção noturna (inconsciente; pulsões), o que repõe a mesa o bom Deus das verdades subjacentes, mas sim de um modo diurno: a descoberta de novas formas de linguagem que não julguem, mas que incrementem a

42 ROBBE-GRILLET. Por um Novo Romance - p.168.

43 ARTAUD, A. Primeiro Manifesto do Teatro da Crueldade in: O Teatro e seu Duplo - p. 107.

44 Por outro lado, o que afasta Agrippino do poeta e teatrólogo francês é que este último cada vez mais vai optar pelas "glossolalias", pelas palavras que explodem ao serem pronunciadas, uma linguagem de qualidades sonoras insuportáveis que afetem diretamente o corpo; enquanto o escritor paulista, homem de tempos em que a palavra se desbasta por si mesma na mixórdia generalizada dos meios de comunicação, vai optar ainda por uma ruminação da palavra, por uma linguagem mais redundante que, justamente por sua monotonia, seja capaz de novos e inesperados sentidos na interpenetração de suas frases e parágrafos. 
vida.

Estão lançadas as bases para uma Arte Soma. Rejeitando cada vez mais as concepções formais e filosóficas que nortearam por quase três séculos a escrita romanesca, especialmente a unidade do conceito de signo e de obra, "lugares" por excelência do sujeito unitário da metafísica, um livro como Lugar Público, ainda que embrionariamente, nos propõe - com sua "crítica da representação" através de uma "dessemiotização generalizada da cultura" 45 - que se abandone sem pesares o conceito de arte como esfera autônoma existente pelo menos desde o Iluminismo. Como substituto, surge esta Arte Soma, esta coleção de "eventos" e "intervenções", para usar o vocabulário "imaterial" de Lyotard. ${ }^{46}$

Embora não deixasse de enxergar seu livro como "obra literária", e como poderia ser diferente para um autor estreante em busca de um lugar ao sol no mundo das letras, Agrippino compreendia perfeitamente bem as implicações que os herdeiros de Mallarmé deveriam enfrentar se quisessem "fazer poesia": essa inumanidade da linguagem, esta total exterioridade discursiva já há muito distante de qualquer verossimilhança. Temos, pois, este lugar público como o palco para uma encenação da literatura, onde singularidades não-literárias causam fissuras no edifício da obra transbordando o ato de escrever romances para uma dramaturgia da escrita. Como neste trecho:

\footnotetext{
"Ela entrou no quarto e ele disse: "Tira o vestido". Ela colocou as mãos para trás e abriu o zíper. Ele segurou o vestido pela manga e ela foi saindo do vestido feito uma pasta de dente e caiu na cama. Ele tirou a camisa, depois a calça, e depois a cueca (...) Ela foi abrindo as pernas e beijava-lhe a boca. Ele tentou penetrar o membro na vagina dela, mas ela virou para o lado e continuou beijando a boca dele. Ele estava molhado de suor e ela estava molhada de suor. "Abre a janela", disse ela. Ele levantou-se, foi até a janela, abriu o vidro e empurrou a veneziana. $\mathrm{O}$ quarto estava escuro (...) Ele segurou o membro rijo entre os dedos e penetrou a vagina dela. Ela voltou a fechar as pernas e ele sentia o sexo úmido dela prender o dele. Ele movimentava o corpo e ela permanecia
}

45 HANSEN. Pós-moderno e Cultura - p. 68.

46 As propostas de Lyotard em substituir a "semiótica" por uma "energética" e a "economia política" por uma "economia libidinal" nos conduzem, no entanto, a duas encruzilhadas: ou abandonamos a noção maior de "estética", e assim corremos o risco de subordinar as artes, a política, a filosofia, enfim, toda a vida cotidiana a lógica da Comunicação (sobre o assunto: SFEZ. Crítica da Comunicação); ou então, como parece sugerir o próprio Lyotard, postulamos a existência de dispositivos pulsionais para pensar esses "eventos", mas não para "representá-los", cuja referência seria o sublime de Kant - e assim vamos, aos poucos, reintroduzindo uma ideia de "totalidade inexpressa da experiência humana" (HANSEN. Idem - p. 69). Se é que eu fui uma criança que entendeu direitinho a lição. In: LYOTARD. $O$ Pós-moderno Explicado as Crianças. 
de olhos fechados. Ele, depois de permanecer alguns instantes repetindo o movimento, sofreu um espasmo e ejaculou dentro da vagina dela. Ela prendeu-se a ele fortemente e ele abandonou o corpo e escorregou para o lado." ${ }^{47}$

Pelo menos desde Flaubert, o romance já conhece esse tipo de autor que maneja a pena como quem maneja o bisturi, essa procura por uma objetividade imanente ao ato de escrever. Nesta passagem de $L P$ percebemos tal imanência reificada: praticamente todas as frases começam com um dos pronomes pessoais da terceira pessoa para deixar claro que nada interessa que não sejam esses corpos em busca de sensações. Esses corpos, aliás, não existem antes da cena-parágrafo, nem existirão depois dela. Seu tempo é o tempo da ação, da sensação. Despidos, literalmente, de todas as condicionantes histórico-psicológicas, o ato sexual é ali menos descrito que encenado. Temos uma deserotização do sexo, da escrita. Note-se, por exemplo, a frase: "ele estava molhado de suor e ela estava molhada de suor". O mais comum seria esperarmos um período mais erótico do tipo "os dois estavam molhados de suor", mas há aqui a necessidade de mostrar, de colocar cada personagem em cena, de rubricá-los, de materializar seus corpos através da repetição dos gestos. Tudo em função de uma teatralidade que tenciona a escritura, como num happenning encravado no verbo. O narrador de Agrippino conduz o gesto literário para uma metafísica da carne que só o teatro, liberto da palavra, em toda sua crueldade, é capaz de realizar. Daí a sugestão aqui implícita de que a pesquisa formal iniciada em Lugar Público desenvolve-se naturalmente para as montagens do Sonda, especialmente $O$ Rito do Amor Selvagem (1969).

Mas não devemos reduzir esse conceito de teatralidade, de dramaturgia da literatura, aquela "prática artística" reconhecida como teatro - estamos aqui nas franjas de uma arte na era da sua condição post-medium. ${ }^{48}$ Sigamos, caro leitor, para além do Bojador. Conforme percebeu o professor Erwin Rosenthal, na segunda metade do século XX a "estrutura do romance torna-se menos rígida, permitindo a penetração de grande quantidade de material alheio a esfera específica da literatura" ${ }^{49}$ Essa afirmação pode ser entendida de muitas maneiras e, ao que parece, Rosenthal estava

47 LP - p. 52-3.

48 KRAUSS. A Voyage on the North Sea: art in the age of post-medium condition (ver bibliografia)

49 ROSENTHAL. O Universo Fragmentário - p. 125. 
pensando mais especificamente na influência da "prosa documental", jornalistica, no universo romanesco. Podemos, entretanto, tirar conclusões mais profundas a partir dela. Já é bem conhecida a influência que a montagem cinematográfica teve na prosa modernista: os cortes rápidos, a justaposição de planos, a descontinuidade da ação... Em Lugar Público há um parágrafo nas páginas 59 e 60 que utiliza claramente um artifício semelhante a montagem paralela para narrar dois acontecimentos distintos numa mesma sequência: um casal de namorados passeando pela praia e um rapaz loiro lendo um livro na biblioteca. No entanto, não é essa presença da "linguagem" do cinema em $L P$ que nos interessa. Eis o seguinte trecho:

\begin{abstract}
"Ele estava estendido sobre o asfalto, rosto colado ao solo, olhar fixo e estático. Os carros passam velozes. A camisa branca, a calça cinzenta, sapatos sujos de lama. Da boca escorria um filete de sangue. A bicicleta estava a poucos passos: a roda girava. Mais adiante um galho de árvore, três latas de querosene (...) Do outro lado da avenida: uma mulher grávida e dois mulatos esperam o ônibus. Os três estacionados junto ao poste onde existe uma placa onde está escrito: 'ônibus'. A mulher olha para a bicicleta, para as latas e depois vira a cabeça para o lado fitando o ônibus que se aproxima. O ônibus passa, a mulher eleva a sombrinha azul para o alto, introduz a mão entre as varetas e abre a sombrinha (...) $\mathrm{O}$ ônibus prossegue pela avenida num agitar constante e monótono. Um rapaz dorme de cabeça pendida, um velho entrega algumas notas ao cobrador do ônibus e este devolve outras notas e uma ficha azul (...) Sobre o muro de concreto: o telhado escuro de uma fábrica. As chaminés soltam uma fumaça branca, homens empurrando carretas sobre os trilhos, armações de ferro, tubos contornando tubos, os dentes cerram, o elevar da bocarra que solta uma poeira negra entre os dentes, o tambor prateado, a pequena escada que contorna o tambor prateado, a barca que penetra no mangue e estaciona sob o guindaste, a corrente em movimento." ${ }^{\circ 5}$
\end{abstract}

O que este excerto nos mostra (o parágrafo se estende por quase cinco páginas) é

que aqui não se trata simplesmente da prosa se apropriando de elementos da gramática do cinema, mas sim da literatura dizendo "eu sou o cinema". Todo o trecho em questão é escrito como um "roteiro" a ser captado, como se as palavras ansiassem secretamente pelas imagens que elas sugerem, como se elas quisessem ser apenas aquilo mesmo, sendo contrárias a qualquer tipo de retórica. Não é gratuita, assim, a semelhança deste trecho com as propostas de Antonin Artaud para um "cinema visual" onde a "própria psicologia é devorada pelos atos." ${ }^{51}$ De modo que quando Susan Sontag,

50 LP - p. 53-5.

51 ARTAUD. Cinema e Realidade. In: Linguagem e Vida - p. 160. 
inspirada em Artaud, se perguntou a propósito da possibilidade de uma arte que não recorresse a interpretação, sua resposta foi a seguinte: "acontece no cinema, acredito" 52 , e completou seu raciocínio dizendo que era quase inevitável que as experiências literárias de Robbe-Grillet e seu romain du regard acabassem se estendendo para o cinema, primeiro tendo o escritor como roteirista em $O$ Ano Passado em Marienbad e depois como realizador de seus próprios filmes. O romance, em sua fuga da interpretação e da subjetividade, teve um encontro ontológico com o cinema; enquanto o cinema, pelo menos um certo tipo de cinema, de grande prestígio ainda em nosso dias, fez o movimento inverso em busca do prestígio da literatura como criação artística autoral. Não seria exagero indicar um caminho parecido na trajetória poética de Agrippino, por isso o estudo de Hitler $I I I^{\circ}$ Mundo no segundo capítulo deste trabalho depende intrinsecamente destas considerações sobre Lugar Público.

Por fim, uma terceira singularidade perceptível a ser levantada num comentário ligeiro: esses personagens de traços intercambiáveis, significantes errantes, com seus nomes históricos, são verdadeiros "carregadores de símbolos", semelhante aos caracteres dos atores nas perfomances - são eles meros "veículos" para os signos em rotação podendo perfeitamente se metamorfosear durante a apresentação na medida em que nestas não existe uma linearidade temática, no máximo um leitmotiv que justifica um encadeamento de ações. ${ }^{53}$ Como já sugeri, há na escrita de Agrippino um parentesco muito grande com os happenings, precursores das performances, como se ambos fossem parte de um mesmo novo movimento na história da arte, aquele mixed-media que vicejou uma gesamtkunstwerk de outra natureza, onde as diferentes manifestações artísticas não se coadunariam em uma harmonia final catártica, mas preferiram sim, cada uma mantendo sua liberdade, fazer uma composição aberta, cheias de ruídos e dissonâncias, conduzindo assim a experiência estética a um novo paradigma. Resta-nos pois a certeza de que sem reconhecermos essas singularidades não-literárias, sem essa polifonia de meios presente em Lugar Público, não há compreensão possível dessa obra, embrião fundador da Arte Soma.

52 SONTAG. Contra a Interpretação. In: Contra a Interpretação - p. 20.

53 COHEN. A Arte da Performance - p. 57. 
Recuperemos então por um instante a definição dada por Mikhail Bakhtin a respeito da forma romanesca, numa comparação desta com a poesia em sentido estrito:

\begin{abstract}
“... o poeta fala em sua própria linguagem. Para aclarar o mundo de outrem ele jamais se vale da linguagem de outrem como sendo a mais adequada para este mundo. O prosador, ao contrário, como veremos, tenta dizer inclusive aquilo que lhe é próprio na linguagem de outrem (por exemplo, na linguagem não literária de um narrador, representante de um determinado grupo sócio-ideológico), e frequentemente ele mede o seu mundo com escalas linguísticas alheias." 54
\end{abstract}

Para o teórico russo, aquilo que caracteriza essencialmente o romance é o seu plurilinguismo, o fato deste constituir-se feito "uma enciclopédia de todas as camadas e formas da linguagem literária." ${ }^{55}$ É justamente isso que distingue o prosador do poeta, pois para este último a pluralidade de mundos linguísticos é inacessível na medida em que tudo aquilo que ele vê, compreende e imagina, ele o faz com os olhos da sua linguagem, nas suas formas internas, e "não há nada que faça sua enunciação sentir a necessidade de utilizar a linguagem alheia." ${ }^{56}$ Ao contrário, o discurso do prosador é eminentemente dialógico no sentido de que a concepção do objeto pelo discurso é complicada "pela interação dialógica do objeto com os diversos momentos da sua conscientização. ${ }^{57}$ Nesse esquema, de patente inspiração hegeliana, Bakhtin parece nos dizer que o romance é a arte literária com maior capacidade de se deixar penetrar pelos liames sociais e históricos, sendo, portanto, a forma privilegiada do discurso poético na modernidade. Partindo de tal constatação de Bakhtin, minha sugestão torna-se bastante simples: pelo seu caráter plurilinguístico, o romance é a forma literária mais aberta a plurivocidade de meios que caracterizará a obra de arte na virada dos anos 50 para os anos 60 - cujo símbolo maior é a irrupção da pop art - tornando-se um laboratório avançado na constituição desta poética híbrida e imaterial, inventora do contemporâneo, onde Lugar Público ocupa seguramente uma posição de destaque.

54 BAKHTIN. Questões de Literatura e de Estética - p. 95.

55 Idem - p. 107.

56 Idem - p. 94.

57 Idem - p. 87. 
Quando seus livros voltaram as prateleiras a partir do relançamento em 2001 de Panamérica pela editora Papagaio, Agrippino, de certo modo, também voltou aos refletores. No meio de um burburinho do tipo “mas esse sujeito ainda está vivo, puxa?!” ele acabou concedendo algumas raras "entrevistas" onde encontramos, permeadas pelas sinuosidades de um pensamento esquizopoético e pela estranheza de um comportamento no mínimo singular (Agrippino passou a se vestir nos últimos anos de sua vida com uma espécie de roupa de pano que era enrolada em seu corpo feito uma fralda e falava durante boa parte do tempo como se ainda vivesse há quatro décadas atrás), algumas revelações de interesse.

Numa dessas entrevistas ${ }^{58}$, por exemplo, quando perguntado sobre seu gosto por leituras no plano da literatura nacional, Agrippino citou dois nomes: Nelson Rodrigues e Jorge Mautner. Sobre o primeiro me absterei de qualquer comentário mais profundo, embora talvez se possa especular sobre as influências deste em Lugar Público, especialmente no que diz respeito a certa obsessão em desnudar os recalques e as idiossincrasias de todo um universo mental de classe média a urbanidade psicótica do escritor e dramaturgo carioca certamente teve seu peso na fatura dos romances de Agrippino. Mas é do segundo que eu gostaria de tratar aqui, mais especificamente das relações entre Lugar Público e o primeiro romance de Mautner, Deus da Chuva e da Morte (1962), na medida em que ambos são igualmente considerados marcos: seja como renovadores da prosa nacional (o livro de Mautner chegou mesmo a receber o prêmio Jabuti para autor revelação), seja como símbolos de toda uma cultura "maldita", "irracional”, "underground” cultuada pela sua aura libertária, mas cujas obras permanecem amplamente desconhecidas, seja como precursores literários (e filosóficos) do movimento tropicalista.

58 Entrevista a Ricardo Soares no programa da TV Sesc "Mundo da Literatura" - 
Nos auspícios de uma poética existencial, metropolitana e miscigenada, Mautner combinou neste seu primeiro livro uma série de relatos confessionais de seus anos de juventude, passados entre uma casa em São Paulo e um sítio no Guarujá, com pequenos contos, lendas e fabulações impregnados de uma mística filosofante. Com o passar dos anos, Deus da Chuva e da Morte tornou-se o primeiro tomo de um conjunto de obras reunidas pelo próprio autor sob o título Mitologia do Kaos. O que interessa a Mautner, portanto, é invocar a partir do narrador romanesco a figura do contador de mitos: "ela era filha de gente exaltada e que bebia fogo" ${ }^{59}$, escreve ele logo na primeira linha de $\mathrm{DCM}^{60}$ como se fosse um grande xamã reunindo num gesto grandiloquente seu séquito de ouvintes à sombra de uma fogueira ancestral. Filho de pai judeu e de mãe protestante, ambos austríacos, Mautner deixa a Europa fugindo do nazismo, para o qual perde grande parte de seus parentes, e aporta no Brasil onde é amamentado por uma negra que o leva para ninar nos terreiros de candomblé do Rio de Janeiro. Sob um céu de bombas atômicas e câmaras de gás, surge no hemisfério sul o anjo redivivo, judeu por tradição, cristão de nascimento, caraíba por vocação, transformando em totens os tabus da cultura letrada europeia.

\footnotetext{
"Eles andavam e estes vegetais esfregavam-se contra a carne deles, das nádegas, das coxas, das costas, dos peitos, enquanto eles andavam ou se movimentavam. ele era imberbe e de carne cor morena ouro. Ela era delicada e faces de Índia misturada com loira. O buraco fervia de emoções. Os dois viviam ali, dormiam ali e comiam ali. Comiam peixes, frutas e camarões. Dormiam no calor. A noite era anil e a lua eu nem imagino de medo de estourarem os meus olhos ."61
}

Eis um pequeno trecho de uma das várias histórias reunidas neste compêndio mitológico que é DCM. Nela, um casal de jovens vive num estado primordial de harmonia e beleza, sendo totalmente livre para desfrutar o etéreo amor da carne e da terra. Mautner sempre se afirmou, antes de tudo, um escritor de utopias românticas. É diretamente do romantismo literário brasileiro, aliás, que ele recupera essa força mitogênica, essa vivência física da natureza, tudo descrito com uma ingenuidade originalmente clichê que cumpre em DCM duas funções primordiais: garantir a escrita

59 MAUTNER. Deus da Chuva e da Morte. In: Mitologia do Kaos vol. I - p. 11

60 Usarei esta sigla quando me referir a "Deus da Chuva e da Morte".

61 DCM - p.126. 
algo como um nexo imediato com as origens das sensações e evitar uma linguagem saturada de implicações morais ao feitio do folhetim. Daí a frase subitamente interromper-se: a lua... nem se imagina... Um traços marcantes do jovem escritor Mautner é, por diversas vezes, se desinteressar ou se julgar incapaz de levar adiante um enunciado, num efeito de suspensão dos sentidos - como se essa impossibilidade essencial da frase reencantasse a escrita através de uma dimensão lúdica, infantil, que arremete contra a ironia profunda da "boa literatura" provocando um efeito inesperado de vivacidade. Isso não quer dizer que ele seja sempre bem sucedido nessa empreitada, pelo contrário, seria má-fé de minha parte não admitir que DCM possa ser, insistentemente, bastante enfadonho - mas me concentrarei aqui nos seus méritos como experimento formal.

A falta de "literariedade" desta literatura acaba por desbastar o subjetivismo romântico responsável por aumentar o hiato entre a consciência e o mundo - aí está o trunfo desta escrita pobre. Com seus períodos curtos, abruptos, cuja ligação sintática é extremamente banal, destacando-se o abusivo uso da oração direta e da conjunção "e", como fica claro no trecho citado acima, Mautner vai compondo uma série de ações e histórias cujo tempo e espaço são indefiníveis, cuja relação entre as partes é inconsistente e cujos pensamentos e sentimentos de seus personagens permanecem vagamente expressos - é a lógica da escritura épica típica do Velho Testamento, abandona-se o efeito de uma linearidade sensorial e bem iluminada da trama em nome de um todo que permanece enigmático, carregado de segundo planos, mas que por isso mesmo é mais unitário: "quanto mais isolados e horizontalmente independentes são os relatos e os grupos de relatos, tanto mais forte é a ligação vertical comum que os mantém todos juntos sob um mesmo signo", e diante desses retalhos "o leitor sente a cada instante a perspectiva religiosa e histórico-universal que confere a cada um dos elementos o seu sentido e a sua meta globais." ${ }^{62}$ Agrippino será bastante influenciado por este estilo de Mautner, mas abster-se-á totalmente de sua metafísica (o próprio Mautner, aliás, dentro mesmo de DCM deixará muitas vezes que sua afetação trágica contamine essa escrita mais pobre, mas sem perder a redundante ternura). Agrippino parece, na verdade, ter escolhido uma das 
vozes do livro de Mautner, levando-a ao paroxismo.

Esclareço pois que a cena descrita no trecho acima, no entanto, em nada se parece com a imagética do Velho Testamento. Esse retrato do mundo antes da queda se assemelha mais a uma das muitas 'visões do paraíso' fomentadas nas diversas vogas milenaristas espalhadas por todo o Medievo europeu, onde o tempo do novo advento se apresentava como um horizonte encarnável. Essa escatologia lançará as dobras do seu imaginário adâmico sobre as "fantásticas" aragens do Novo Mundo e resquícios de seus 'mil anos de felicidade' chegarão até a ideologia romântica do indianismo literário e seu elogio da americanidade. Mautner nunca escondeu ser dignatário dessa tradição: é a partir da mentalidade romântica, dessa "concepção de mundo preponderantemente idealista e metafísica, percorrida por um afã de totalidade e de unidade, própria da sensibilidade conflitiva que a impulsionou, polarizada por sentimentos extremos e atitudes antagônicas" "63, que ele lê a história dos tempos. É justamente essa sensibilidade conflitiva que lhe permite invocar discretamente as formas da grande Épica, e sua totalidade espontânea do ser, por meio da descontinuidade do romance moderno: “os pulos na escrita são próprios de uma nova era, o nervosismo da sua chegada" (p. 71). Uma Nova Era que só pode advir do Novo Mundo:

\begin{abstract}
“É daqui que vai nascer a nova fé. É do Brasil, não sei porque mas é do Brasil! Eu sou filho de eslavos e judeus mas nasci no Rio de Janeiro no tempo em que ele era Distrito Federal. E só digo o que penso, só faço o que gosto, e aquilo que creio. Eu tenho em mim o sangue atormentado e o sol do novo mundo. É aqui a ressurreição! É aqui a nova vida! É aqui, das cinzas, por que a morte é necessária? Eu não sei. Deixem-me pelo menos lançar esse grito de esperança". ${ }^{64}$
\end{abstract}

Como a seiva do porvir que percorre os músculos desse estatuário de colossos que é a América do poema de Castro Alves, ${ }^{65}$ a chuva em DCM é o símbolo da fertilidade do advento. Ela expia os corpos que estão envolvidos pela Morte - o ciclo que se completa, a derrama sagrada, o sangramento necessário para fecundar os dias. Feito Rômulo e Remo, feito Esaú e Jacó, Chuva e Morte são os artíficies de uma Renascença sempre renovada. Aqui paira sob o livro a sombra de

63 NUNES. A Visão Romântica in: GUINSBURG (org.) O Romantismo - p. 53.

$64 \mathrm{DCM}-$ p. 158

65 Trechos em itálico retirados do poema de Castro Alves, O Livro e a América. 
Nicolai Berdiaev. Mautner chega mesmo a citá-lo textualmente por diversas vezes no corpo do seu livro. Oferecendo uma estrutura de consciência que fugia aos moldes da dialética hegeliana do senhor e do escravo, o filósofo russo Berdiaev, as vésperas da Revolução de 1917, postulou a existência préontológica da liberdade, do "homem livre". Cristo seria assim o protótipo deste homem livre. Em sua obra mais famosa, A Nova Idade Média, Berdiaev não poupou críticas radicais a devastação da vida causada pelo progresso tecnológico. Esse furor crítico de inspiração dostoievskiana era de todo contrário ao humanismo democrático, calçado pela eficácia burocrática, e a favor da sensibilidade criadora e libertária. A essa hegemonia da técnica, Berdiaev chamou de aurora de uma "Nova Idade Média”, o cativeiro civilizado pela qual devemos passar antes que rompa um novo e inimaginável Renascimento. Desde os tempos de estudante Berdiaev abraçou o marxismo, chegando mesmo a participar ativamente da Revolução de 17, mas nunca abandonou um tipo de pensamento existencial cristão que era chamado, principalmente por detratores, de "realismo místico" e que lhe valeu o exílio em 1922. É essa combinação de Marx e Kierkergaard que impressionou Mautner: "eu digo que o socialismo radical, ou bolchevismo, ou comunismo é a verdade, o bem, a justiça, embora me seja talvez desagradável, para mim, como indivíduo, criatura egoísta, enfim, burguês” (p.192) - só que o bardo paulistano interpreta a teleologia cristã-socialista de Berdiaev com os olhos (e as bocas) de uma cultura antropofágica:

\footnotetext{
"Uma Nova renascença nunca chegará a se desligar dos laços profundos que a unem com a Nova Idade Média pois este seria seu fim, seria a chegada do humanismo! E por isso não haverá Renascença mas sim uma eterna pré-Renascença eternamente Nova! (...) Luz e escuridão unidas e tão juntas que se confundem (...) África, Brasil, América Latina, tudo tudo coisa nova e porque não renascença também Nova? Entendam! É a crise do adaptacionismo."
}

É na crise da filosofia messiânica, na retomada da antropofagia como modo de pensar as contribuições do (in)civilizado aos dilemas da modernidade (entre eles a própria "crise do marxismo" perante o horror estalinista) que Mautner encontra-se com o filósofo Oswald. Essa eternidade pré-renascentista guarda algo daquela vitória final do Matriarcado ${ }^{67}$, assim como essa Nova

66 DCM - p. 204.

67 Onde a longa história da racionalidade patriarcal é substituída pelo direito materno, pela propriedade comum do solo e 
Idade Média, transfigurada, colocada agora sobre seus próprios pés, também traz os ecos que Oswald atribuía ao medievo cristão, principalmente esta contemplação da alegria suprema que é Deus: o ócio puro; mas sem que seja necessário agora aquela hierarquia do ócio que organizou o Ocidente. ${ }^{68} \mathrm{~A}$ barbárie tecnicizada é uma imagem que podemos vislumbrar nesse desfile de novidades, de eternidades, onde as contradições e vicissitudes da "cultura brasileira" despontam como a prova dos nove de uma novo momento para o homem, nas antípodas de tudo aquilo que Graça Aranha havia repelido em sua Estética da Vida como um apego tenebroso ao espírito da terra que teria transformado a imaginação brasileira num fetichismo acaboclado. O Brasil é o palco estratégico onde o choque de civilizações se decidirá. ${ }^{69}$ Para tanto, bastaria perceber que toda a "geografia das Utopias situa-se nas Américas": ${ }^{70}$ Morus teria escrito seu Tratado depois de ouvir os relatos, em Flandres, de alguns homens deixados por Américo Vespúcio na feitoria de Cabo Frio; Montaigne escreveu seu notório ensaio sobre os canibais, berço das virtudes originárias do homem natural, tendo em mente os índios brasileiros; igualmente Rousseau e, portanto, toda a filosofia esclarecida que fomentou a Revolução Francesa e o pensamento libertário do século XIX, chegando até a imagem do homem como animal de presa, o raubentier descrito por Nietzsche em Genealogia da Moral. O Kaos de Mautner é assim, ao mesmo tempo, o ponto de chegada de um longo processo civilizatório e um retorno bárbaro, uma versão antropofágica daquele caos que o ubermensch deve trazer dentro de si "para fazer brilhar a estrela bailarina", conforme o prólogo do Zaratustra. ${ }^{71}$

Nas ameias deste advento, a filosofia e a literatura devem tornar-se outra coisa, devem abandonar as minúcias técnicas para ressurgirem como uma grande reescritura de mitos. Uma religião filosófica, sem templos, cultos ou liturgia, uma contemplação extática do mundo e do cosmos

pelo Estado sem classes ou ausência de Estado. In: ANDRADE. Crise da Filosofia Messiânica - p. 129.

68 ANDRADE. A Marcha das Utopias- p. 158 (ambos os textos estão reunidos no volume “A Utopia Antropofágica”)

69 Tal percepção tem fama em nosso pensamento letrado e ganha especial interesse nos anos 60, tempos de Guerra Fria e hecatombe planetária. Veja-se, por exemplo, como ela aparece, travestida em uma defesa do mundo cristão contra a ameaça do ateísmo soviético na Geopolítica do Brasil, do General Golbery. O papel decisivo do Brasil na harmonia universal das esferas e a importância de preparar esta nação para assumir seu papel neste arranjo de forças era o que unia os pensamentos desses algozes no teatro político, Golbery e Darcy Ribeiro, os dois "gênios da raça", conforme a famosa definição de Glauber Rocha.

70 ANDRADE. A Marcha das Utopias - p. 151

71 NIETSZCHE. Assim Falou Zaratustra - p. 19 
tal como refletido no horizonte da alma: eis o kaos. Isso é apreensível formalmente no romance se considerarmos a forte dimensão "confessional" da obra, em que o autor, por vezes, entremeia aos contos e histórias exemplares, pequenos relatos pessoais, cartas, bilhetes, poemas, onde a argumentação, digamos, "filosófica", é o resultado imediato da história pessoal do autor. Ao reescrever o mundo a partir do Kaos, Mautner novamente traça uma longa viagem a noite medieval dos tempos, buscando inspiração em certa tradição teológica da Igreja, principalmente Agostinho, imiscuindo as Confissões no ventre da Cidade de Deus. Há certo encantamento agostiniano no pensamento de Mautner na medida em que este, por vezes, renuncia a uma disciplina teórica sustentada por qualquer perspicácia lógica que se indague incessantemente sobre a composição do universo físico ou à natureza dos deuses. Para Mautner, o kaos é, em princípio, uma indagação sobre a condição humana, sendo que a única razão para o homem filosofar é atingir a felicidade. Mesmo assim, como bom profeta da era tecnológica, ele não vai renunciar completamente as miríades de uma ciência dos mistérios.

Mitologia, filosofia e romance confluem assim para a criação de uma literatura de impurezas, para além dos gêneros e disciplinas, ou como se dizia na gíria hippie dos anos 60: uma realização "inconscientífica”. Aqui Mautner encontra outro dos seus heróis, igualmente muito citado nas páginas de DCM: Arthur Koestler. A ânsia de totalidade do escritor paulista almeja ser capaz de unir as duas fases do escritor húngaro: uma primeira fase de autor engajado, de preocupação social, onde a experiência pessoal, jornalistica, é transformada em matéria para seus romances, como em $O$ Zero e o Infinito (1941); e uma segunda fase, mais especulativa, para qual a primeira conflui na medida em que a utopia deixa o universo do social, das transformações políticas, para abrir-se a busca de uma "ciência" espiritualizada, como no famoso Ghost in The Machine (1967). Mautner transita de uma fase (e face) a outra no mesmo livro, no turbulento caminho da descoberta do Kaos que vai do comprometimento com a cartilha do Partido Comunista, que ele frequentou na primeira metade dos anos 60, aos passeios pelas "ciências do desconhecido" ou pelas filosofias não-ocidentais. Nada impede que a ditadura do proletariado possa usufruir das mais variadas terapias alternativas, das 
energizações, das promessas de expansão da consciência através do uso de psicotrópicos, nada impede que ela se encante com os problemas trazidos pela ufologia ou pela parapsicologia, nada afasta, enfim, a mecânica da luta de classes do tao da física. Eis a geléia geral que fará despertar o paladar para o banquete tropicalista. "A fé sempre foi a mais rigorosa das ciências"72

Tal passeio (existencial) por esses modismos científico-filosóficos guarda certamente algo de kitsch, mas assim como esse fascínio aberto pelos mass media, trata-se sempre de estar mais perto do coração solar da vida. O kitsch das manifestações de massa, da qual inclusive fazem parte as vulgatas filosóficas e científicas, seria a fonte primária para um renovado sentimento estético, para a verdadeira libertação do pavor e da psique, já que ele é igualmente contrário a opacidade humanista, as rédeas da tradição liberal-burguesa. Daí os mitos de Mautner se impregnarem de um vasto sistema de referências à cultura de consumo que vai dos motoqueiros wild ones dos filmes da juventude transviada, até os boleros dor-de-cotovelo de Nelson Gonçalves. É tão forte a presença desses espectros massificados que, vez ou outra, eles acabam tornando-se personagens do romance: é o caso de Maísa, a cantora de olhos azuis, que aparece em algumas das histórias do livro não como uma figura real, a condessa Matarazzo, mas sim como esta Maísa só conhecida na matéria da qual os sonhos são feitos. É o caso também de James Dean, talvez o maior fenômeno de mitificação midiática instantânea de toda história da indústria cultural (só comparável a Marylin Monroe e Che Guevara, não por acaso dois dos personagens de Panamérica). Como fica patente, aqui está outra grande influência de DCM sobre Agrippino: essa transmutação de figuras pop em personagens do romance, esse aproveitamento poético do signos da mass culture:

\footnotetext{
"A chuva era forte e era escura. Havia um verdor de musgo e de lenda marítima, e um cinza de chuva com tristeza de samba-canção. Depois ele ofereceu a ela um pouco de sua coca-cola. Ela bebeu. Ela derramou leite no cabelo dele. Riram. Se beijaram. Se beijaram mais uma vez. Depois se morderam. Coca-cola, leite, amor. Eles se deitaram na grama do jardim da casa dela. Escuridão, sangue, leite, cor, coca-cola, amor! Por mais que eles pratiquem o ato sexual eles serão sempre virgens, porque a pureza deles é um fato consumado. Eles se agarram e grudam e ele mordeu o seio dela como se mordem as maçãs e etc, e etc. Depois ele pegou ela pela mão e disse: - 'Vamos para o mar!' E olhando-a nos olhos cheios de
}

72 MAUTNER. Fundamentos do Kaos in: Mitologia do Kaos v. II - p. 430. 
A coca-cola derrama-se sobre a terra e os corpos como o mel que jorra da terra prometida - a nova Canaã da era industrial. Muito do estilo e da mitologia mautneriana estão presentes neste trecho. Encontramos novamente as frases inacabadas - "e etc., e etc."; os excessos de repetições, aditivos e conjunções; além daquela ingenuidade infantil da fala: "vamos para o mar, lá tem coisas bonitas". Essa comunhão carnal entre "Ele" e "Ela" remete-nos inclusive a cena de Lugar Público já citada por mim neste trabalho (p.18), mas perceba, amigo leitor, que a série de elementos que cercam agora o casal: a chuva, as maçãs, a coca-cola, o mar, dão a cena uma clara dimensão erótica - que também está nos corpos, nos beijos, nos olhos cheios de amor - em tudo estranha a prosa de Agrippino. A comunhão é coroada então pelo uso da terceira pessoal do plural, seja nos tempos verbais, seja no pronome “eles”, inteiramente banido, conforme já salientei, da cena em LP - há uma transcendência (amor) nesta união que inexiste na outra. Temos então, novamente, uma confirmação da tese que começa a ganhar viço nesta análise: Agrippino se inspira nas invenções estilísticas de Mautner, mas se exime de sua visão de arte e de mundo, ou seja, sua escritura é de ordem (ou caos) distinta. Isso será de fundamental importância se quisermos compreender o projeto da Arte Soma.

Voltando a DCM, e ao trecho em questão, saliento que nos deparamos novamente aqui com o esquema modelo dos contos de Mautner: em boa parte destes contos, por exemplo, temos sempre uma figura feminina virginal, pura, que se complementa numa metade oposta, uma figura masculina igualmente jovem e pura $^{74}$ - é o mesmo esquema de organização encontrado no trecho da nota 59 supracitada. A paisagem os envolve, os consome, como se partilhassem o mesmo substrato profundo. Isso se deve ao uso que Mautner dá em seus livros ao mito: eles possuem certas características comuns aos sonhos e aos contos de fadas, em especial esta indistinção aparente entre a Cultura (a "coca-cola") e a Natureza (o "sangue"). A repetição serve assim para tornar manifesta a estrutura do mito.

73 DCM - p. 161-2.

74 As vezes podemos encontrar um jovem de alma pura, mas acanalhado pelo ditames de sua classe social. É o caso do "playboy" em Historinha de Amor. In: DCM - p. 232. 
Como está evidente, essa minha leitura da mitologia mautneriana me aproxima de algumas das famosas considerações de Lévi-Strauss sobre o mito. "A substância do mito não se encontra nem no estilo, nem no modo da narração, nem na sintaxe, mas na história que é relatada." ${ }^{95}$ Essa história que se conta adquire simultaneamente nas suas versões (e todas as versões são o mito) uma dimensão temporal reversível, não-histórica, e uma dimensão temporal irreversível, histórica: um mito decorre num momento de tempo, mas também numa estrutura permanente; ele pertence a fala e também a língua. Já havíamos percebido algo muito semelhante quando analisamos a organização interna de DCM - o tempo do kaos é o agora da ação e o devir da Nova Era. Devemos nos perguntar então, o que é o mito: essencialmente, ele é linguagem, mas sendo linguagem, ele a supera, indo além do nível habitual da expressão linguística: o mito está subentendido no sentido manifesto, no seu “não-sentido". E qual a função do mito: "fornecer um modelo lógico para resolver uma contradição"76 . E qual seria essa contradição: segundo Strauss, não há uma resposta única, mas ele fornece um modelo básico com sua análise do mito de Édipo. Neste mito, como em tantos outros da mitologia grega, trata-se de "afirmar a impossibilidade em que se encontra a sociedade que professa a crença na autoctonia do homem de passar, desta teoria, ao fato de que cada um de nós nasceu realmente da união de um homem e de uma mulher". ${ }^{77}$ Resumo: a contradição em "ser homem" e também "ser parte do mundo". Se voltarmos então ao trecho de DCM citado logo acima vamos encontrar justamente essa contradição: esse casal primordial (a binaridade da criação: masculino e feminino; fala e língua; sincrônico e diacrônico; consciente e inconsciente) que permanece sempre virgem por mais que "pratiquem o ato sexual". Onde Mautner se distancia do cientista social Strauss é na sua "fé cientifica no kaos": a desordem que unifica.

De qualquer modo, o mito já é um primeiro tipo de esclarecimento sobre a separação consumada entre homem e mundo. ${ }^{78}$ Mas como forma, o mito tem uma característica que lhe confere uma aura de transcendentalidade: ele conhece somente respostas - nenhuma pergunta,

75 LEVI-STRAUSS. A Estrutura dos Mitos in: Antropologia Estrutural - p. 242.

76 Idem - p. 264

77 Ibidem - p. 249

78 Um dos temas básicos da Dialética do Esclarecimento de Adorno e Horkheimer. 
apenas soluções (mesmo que enigmáticas). ${ }^{79}$ Foi André Jolles quem brilhantemente nos mostrou que um mito é, antes de tudo, uma resposta a uma pergunta; mas não só, pois se a pergunta era simples (por exemplo: afinal, o que é o sol?), a resposta é estruturalmente cada vez mais complexa, ao ponto de alcançar tamanha natureza que não seja mais possível formular outras perguntas; ao ponto da própria pergunta original acabar anulada - na fórmula de Jolles: a pergunta anula-se no mesmo instante em que é formulada, a resposta é decisiva. ${ }^{80} \mathrm{O}$ mito então 'organiza e cria' ao mesmo tempo, construindo uma "malha literária" capaz de compreender o mundo sem necessitar de argumentos extrínsecos. De certo modo, a literatura partilha com o mito essa dimensão criadora de perguntas e respostas - assim como a verdade mítica, a literatura não precisa de verificações.

Mautner, para quem, como Glauber, só interessava a profecia, vicejará então reunir o sujeito da hermenêutica e a "malha literária do mundo" numa reescritura mística de mitos, onde aquelas perguntas originais indefiníveis se perpetuam silenciosamente no grande mistério do kaos, que por sua vez, deve ser sentido interiormente, como numa experiência religiosa, para depois encarnar o "vir-a-ser" da história (nesse "não lugar" que só pode ser o Brasil). Estamos aqui muito longe do caos de Agrippino:

\begin{abstract}
"Estou numa confusão absoluta de palavras e de sentido. Um jogo. Um novo jogo de palavras. Uma sonolência. Fadiga de existir. Sonolência. O meu estado geral de existir é a apatia. Enfrentar a loucura. Enfrentar a própria loucura e enfrentar a loucura do mundo. Sempre no limite da razão-loucura. Construir a ordem da falta de ordem." ${ }^{\text {"1 }}$
\end{abstract}

Conforme demonstra o percurso deste trabalho, o livro de Agrippino parte da angústia do existencialismo, desta "fadiga do existir", para no caminho, rumo a este enfrentamento com a loucura do mundo, encontrar Jarry: esta "ordem da falta de ordem" lembra a Patafísica, a ciência das leis que governam as exceções. Durante muito tempo o autor de Ubu Rei foi considerado o grande gênio de uma só obra, o precursor "maluco" das vanguardas, o inventor do teatro moderno, mas seus escritos posteriores eram considerados descartáveis como bobagens anedóticas. ${ }^{82}$ Pois é

79 É dessa forma, por exemplo, que Lukács define o “mundo grego”. In: LUKÁCS. Teoria do Romance - p. 27.

80 JOLLES. As Formas Simples - p. 87.

81 LP - p. 250

82 "Nem todos os estudos de Jarry podem ser levados a sério" alertava Otto Maria Carpeaux no prefácio da edição 
justamente no momento em que Agrippino está escrevendo o seu romance que se dá uma revalorização massiva do Jarry pensador na França, culminando no famoso ensaio de Deleuze: “ Um precursor desconhecido de Heidegger, Alfred Jarry". ${ }^{83}$ Ora, o que teriam Agrippino, Heidegger e Jarry em comum? Simples: a superação da Metafísica. Somos um acontecimento que está só no mundo e que se espanta consigo mesmo. É preciso, assim, construir a ordem dessa falta, desse espanto.

É como "acontecimentos", como pequenos espantos, que a obra de Agrippino é construída, que a ordem da desordem (este Lugar Público) se insinua. Sua escrita é aforística: daí a independência de seu parágrafos que explodem diante de nossos olhos assim que terminamos sua leitura. Agrippino parece ser, de todos os artistas brasileiros do seu tempo, um dos poucos, senão o único, capaz de levar a cabo uma arte que não julga a vida, opondo-lhe pensamentos superiores, mas sim que "afirma a vida" ${ }^{\sharp 4}$. E talvez seja justamente por esse motivo (e um pouco por seu comportamento pessoal, por sua fala grave e pausada), por não deixar de ser poeta para tornar-se metafísico, que Agrippino tenha ganhado fama de "profeta do caos", sendo que sua obra literária nada tem de profética - a menos que a consideremos uma profecia da falta de profecia, o que nos remete diretamente para a "ordem da falta de ordem".

Mas essa aparente "tautologia", nos revela, na verdade, uma repetição de ordem distinta daquela que descrevi acima sobre a mitologia mautneriana. Pois a falta de ordem já não é um retorno à ordem, um "retorno do mesmo", é a apenas a volta (à ordem) que é a mesma. Resumindo: não se trata de um ciclo. Há, por exemplo, frases que se repetem ao longo de LP, como "ele foi eliminado da mesa de jogo, não que ele fosse um dos jogadores, ele era umas peças do jogo", frase encontrada nas páginas 148 e 189, só que embora estas sejam frases gramaticalmente idênticas, elas não são a mesma, pois o "contexto" ou o "lugar” em que a repetição se dá faz da segunda delas um

brasileira de Ubu Rei, onde ele também chamava o College de Pataphysique fundado por Queneau de uma "sociedade de mistificadores" cujo negócio estava francamente desmoralizado. Carpeaux concentra os verdadeiros méritos de Jarry exclusivamente em sua obra teatral, fonte primeira de todas as vanguardas. Ver: CARPEAUX. Happening Ubu. In: JARRY. Ubu Rei - p. xiii.

83 In: DELEUZE. Crítica e Clínica.

84 É bem provável que daí venha a "impressão" de Caetano Veloso, descrita ao longo de Verdade Tropical, de que Agrippino sempre parecesse estar "mil anos a frente" de qualquer assunto estético discutido a sua volta, nunca parecendo se interessar pelas questões "nacionais" em arte, então em voga em candentes debates. 
novo acontecimento. É o famoso efeito "Pierre Menard" ${ }^{85}$ Temos então o oposto de DCM onde apesar de cada história ser diferente das outras, elas são sempre a mesma. Proponho então a seguinte fórmula: o kaos de Mautner é o múltiplo do Uno; e o caos de Agrippino é o Uno do múltiplo.

Daí deriva que Mautner seja dono de uma escrita turbulenta, desigual, enfim, barroca, enquanto Agrippino, arquiteto de formação, possua um gosto patente pelo clássico, pela “ordem”, por um senso de proporção notável no esquadrinhamento dos parágrafos em Lugar Público, no arranjo dos capítulos de Panamérica (com seus vinte monolitos de texto, sem parágrafos, nem travessões) e também nos enquadramentos de Hitler III Mundo. Esse fascínio pela construção virtual do espaço pode ser igualmente encontrado nos títulos das obras de Agrippino: "Lugar Público", "Panamérica", "Hitler III Mundo", "Planeta dos Mutantes", todos compreendendo aquilo que chamarei de "cartografia imaginária". Enquanto, de modo oposto, o livro de Mautner nos remete sempre a um espaço em conflito, a uma unidade cindida (e novamente ansiada) por este Deus que é céu (chuva) e que é terra (morte) - barroco por vocação e por definição.

Esse "barroquismo" de Mautner concebe, evidentemente, o mundo como um grande teatro, daí sua impressão: “eu estou milhões de anos na frente do existencialismo por causa da minha teatralidade" (p. 66). Teatro como representação da inconstância, da transformação, da beleza que não está na harmonia e na simetria do imutável, mas no movimento incessante das coisas. Nesse desarranjo geral resta ao homem o desespero e a incerteza, mas esse kaos é compensado pela dimensão romântica e trágica de Mautner, como já vimos. Ele diz: “no nosso teatro existencial nós nos fantasiamos e vivenciamos todos os mitos apenas para purgá-los, para transcendê-los em direção ao eu profundo". 86

Agrippino, de outra maneira, não se interessa pela representação teatral do movimento (das consciências; dos povos): quer fazer uma obra que seja ela própria movimento, que aja diretamente sobre o espírito. Movimento que não é o espaço percorrido dentro de um tempo, conceito abstrato, mas é o movimento da Physis e da Psique. Os personagens de Agrippino não tem 85 BORGES. Pierre Menard: autor do Quixote. In: Ficções. 86 MAUTNER. Fundamentos do Kaos - p. 424. 
papéis, como já notei ${ }^{87}$, sua única função na narrativa é produzir algo novo. Seu horizonte é uma dramaturgia que ultrapasse o teatro - a Arte Soma é esta ultrapassagem. Na transição de Lugar Público para Panamérica perceberemos que cada vez mais Agrippino escreverá como um encenador: a maneira como descreve uma ação ou um personagem soa quase como observações de direção para uma peça que vai se dar no íntimo do leitor como uma "potência terrível". Esse ímpeto se cristaliza no seu texto para a cena Nações Unidas, que começa com observações gerais do autor-encenador destacando que o importante é que o espetáculo "aconteça" e não o drama escrito: "o autor não escreveu um bom texto e foi muitas vezes displicente ao redigir a parte falada da peça" (Página 1 manuscrito), ressaltando mais adiante que "o objetivo essencial do show é não se desenvolver segundo o autor e o diretor de cena, mas cair no caos comandado pelo público" (Página 2 manuscrito; grifo meu). Agrippino tornou-se, finalmente, um encenador do caos. De LP a Hitler III Mundo vemos um continuo incremento desse teatro onde experimentamos "uma linguagem que fala antes das palavras, gestos que se elaboram antes dos corpos orgânicos, máscaras antes das faces, espectros e fantasmas antes das personagens". ${ }^{88}$

No caso de Deus da Chuva e da Morte, a dimensão cênica se dá numa espécie de "teatro do inconsciente". Por isso Glauber Rocha pôde dizer tranquilamente a época: "se eu fosse me definir, diria que sou do Kaos de Mautner" ${ }^{\text {- }}$ - pois ambos partilham esse teatro que tem como palco o inconsciente coletivo da nacionalidade. O título do livro de Mautner teria, inclusive, servido de inspiração para Deus e o Diabo na Terra do Sol do cineasta baiano. Nessa tensão dialética entre vida e morte, entre o eterno e o histórico, a criação artística através da linguagem é a deflagração do absoluto, um sopro de eternidade. Nesse sentido, Raquel Gerber comenta:

\footnotetext{
"Sobre o filme $D i$ Glauber escreve: 'no campo do metafórico transpsicanalítico materializo a vitória de São Jorge sobre o Dragão (...) eu interpreto São Jorge". Glauber, o Santo Guerreiro. O Santo do povo. O autor - o próprio mito? Glauber Rocha busca o caminho da eternidade. E os mitos que recria transitam do eterno para o histórico na reencenação
}

87 A exceção aqui é o narrador-personagem de Lugar Público, que cumpre minimamente uma função de alter-ego do autor, o que justamente permite que chamemos esse primeiro livro de Agrippino de romance. O salto rumo a epopéia, dado em Panamérica, é uma tentativa de livrar-se dessa figura do narrador subjetivado.

88 DELEUZE. Diferença e Repetição - p. 31.

89 A declaração é destaque no release de lançamento da caixa contendo as obras completas da Mitologia do Kaos. 
O autor encarna-se no mito: como o São Jorge de Glauber, Mautner também criou para si um arquétipo: o "vigarista Jorge", que vai aparecer em muitos dos seus livros (um deles denominado justamente Vigarista Jorge e que possui a duvidosa honra de ser talvez o primeiro livro “caçado" pela censura após o golpe de 64). Esse 'arquétipo Jorge' surge logo no começo de DCM, naquele que pode ser considerado o "conto" fundador de toda a prosa de Mautner: O Moço da Motocicleta. Sua função, como arquétipo, é servir de "ligação" entre os dois polos estruturais do mito, ele representa ora a figura do "conselheiro" que auxilia os dois jovens no seu caminho rumo a verdade do kaos (aquilo que Campbell chamou de figura-mestra que vem ao auxílio do herói num dos estágios fundamentais - estágio 3 - de sua mítica jornada ${ }^{91}$ ); ora a figura do trickster, que prega peças e desrespeita as regras normais de comportamento (Levi-Strauss já havia, aliás, identificado os “tricksters" como os "mediadores entre o céu e a terra"92) - e quem sabe a definição de poeta beatnik não seja justamente essa, um “conselheiro-trickster”? Em ambos os casos, trata-se de interferir, para além da autoria, no mundo, de colocar-se, como mito de si mesmo, "na obra". É uma postura sacerdotal, mágica, hermética.

O Vigarista Jorge, de Mautner, parece de fato uma nova manifestação do “Hermes the Thief” de Norman O Brown. Hermes (herma - monte de pedra), a tendencia psíquica inata a dar limite as coisas, limites da consciência. No entanto, quando tais limites são estabelecidos, surge o fascínio pelo “além”, pelo “desconhecido”. Hermes é aquele que nos convida a conhecer outros espaços, é o limite cambiante entre o consciente e o inconsciente. Suas intervenções criam novas possibilidades de consciência. A aparição de Hermes marca a introdução de um princípio diferenciador dentro de um vazio pleromático - as estátuas sempre representavam Hermes com o falo ereto (instinto de criatividade): o bruxo. Igualmente no vocabulário junguiano, e o teatro do inconsciente de Mautner e Glauber guarda essa dimensão mítica e coletiva característica do 
pensamento do discípulo herético de Freud, Hermes é uma figura que significa a união entre uma tendência inata de parte da psiquê para criar limites e definir espaços (arquétipo) e um incessante instinto de criatividade. Quando ele aparece, um novo espaço é criado, um novo espaço de criação e destruição.

O santo guerreiro Glauber e o vigarista hermético Mautner são concretizações no mito do inconsciente do artista, que por sua vez "encena" na arte os mitos da memória coletiva: "o sonho é a mitologia privada do que dorme e o mito é o sonho desperto dos povos; ao Édipo de Sófocles e ao Hamlet de Shakespeare corresponde a mesma interpretação que ao sonho", ${ }^{93}$ conforme escreveu o filósofo francês Paul Ricouer. E como o palco estratégico dessa encenação é o Brasil pobre e subdesenvolvido, onde se dá, como já dito, a culminação geográfica das utopias, esse teatro do inconsciente só pode traduzir o processo de "descolonização do imaginário": na dialética do oprimido, a medida que eu tomo consciência daquilo que sou, reivindico o ser que eu sou, isto é, sou o projeto de recuperação do meu próprio ser. Assim, é requerida certa violência do espírito no projeto de recuperação de si que está na assimilação do outro: em Glauber essa violência é a fome; em Mautner é o retorno ao kaos. Ambos, no entanto, se valem da recuperação que devo fundar em mim a partir da possessão que o outro faz de mim: por isso o Terceiro Mundo, o grande outro do mundo civilizado, é o lugar privilegiado da profecia.

O caminho poético de Agrippino para a Arte Soma parece seguir outra direção: mesmo quando ela nos revela uma porção mais recalcada, mais inconsciente de nosso imaginário, sua proposta não é transcender os mitos, purgá-los, mas sim experimentá-los como a imanência do transcendente. Se em Lugar Público, livro de estréia, o autor/personagem trava ainda uma luta psíquica contra a família, aos poucos substituindo a dimensão do desejo (a mãe) pela dimensão da lei (pai), sendo a figura do pai morto, que percorre todo o livro, um tipo de fundamento último da ordem simbólica, edificando assim o sujeito da letra, ele também já ensaia um abandono do relato intimista e do narrador introspectivo, esvaindo as metáforas psicanalíticas na medida em que o interesse recai

93 Citado em GERBER. Opus Cit. - p. 38. 
não sobre os complexos que explicariam o funcionamento profundo da mente, mas sobre a impotência essencial do pensamento. Os "mitos" tal como apresentados em Lugar Público vão progressivamente se afastando de sua condição de projeções de desejos inconscientes para tornarem-se a pele humana das coisas, uma certa agitação dos objetos:

\begin{abstract}
“As agitações diárias só tem valor enquanto reação a essa espécie de terrível lirismo que existe nos Mitos aos quais coletividades imensas aderiram. É por isso que, em torno de personagens famosas, crimes atrozes, afetos sobre-humanos, tentaremos concentrar um espetáculo que, sem recorrer as imagens expiradas dos velhos mitos, se revele capaz de extrair as forças que se agitam neles." ${ }^{94}$
\end{abstract}

E ao sermos confrontados com essa (im)potência deflagrada pelos mitos, nos damos conta, nos entreatos de cada parágrafo, da única coisa que nos interessa: o fato de que ainda não começamos a pensar. ${ }^{95}$ Não se trata apenas na obra de Agrippino de uma "montagem e desmontagem de mitos", como bem apontou Evelina Hoisel num sentido barthesiano de que "a melhor arma contra o mito é mitificá-lo a ele próprio", ${ }^{96}$ mas trata-se também de através do mito redescobrir aquilo que somos: a dimensão profunda do corpo (não o "corpo físico", mas sim esse corpo que é sempre o próprio irrepresentável de si - o Uno do múltiplo). Enquanto o 'Vigarista Jorge' de Mautner invoca Hermes, o deus do inesperado e da sincronicidade, aquele que habitando o espaço do entre possui a habilidade da linguagem para promover sínteses (saltos) entre informações; Agrippino se interessa por esse entre de modo distinto: mais como o espaço por onde o todo é sempre recolocado apesar de impensável.

Esclarecido minimamente esse ponto central, surge um problema em Lugar Público que é prontamente detectável pelo analista. Como já comentei em outro momento deste trabalho (p. 22), Agrippino não parece ainda não ser capaz de levar em LP esse projeto do espanto, do caos, do impensado, até a sua inflexão. Nesta primeira obra, ele não passa de um experimento. Em parte porque, conforme também já apontado aqui logo na primeira página, como escritor estreante ele

94 ARTAUD. O Teatro e a Crueldade. In: O Teatro e seu Duplo - p. 96. A premissa básica de Panamérica é extrair a força que se agita nessas personagens famosas (novo mitos) sem recorrer as imagens expiradas da tradição.

95 Esse talvez seja um dos sentidos mais aproximados para aquilo que Artaud chamou de "crueldade".

96 HOISEL. Opus Cit. - p. 85. 
ainda se vê totalmente embaraçado pela porção autobiográfica de sua escritura, pelos recalques e incertezas de um neófito. Em segundo lugar, e aqui a coisa fica mais interessante, porque a história também pode aprontar das suas: essa “ordem da falta de ordem" que Agrippino arquitetou em parte muito ligado a questões estéticas então em voga nos Estados Unidos e na Europa, pisou em falso quando confrontada com o delírio transatlântico do golpe: o teatro político de 64 veio de encontro ao caos. Como não se perguntar se transplantada essa fleuma vanguardista da "ordem da falta de ordem" para o III Mundo, não percebemos que a falta de ordem sempre foi a nossa ordem - transformar a exceção numa forma permanente de governo? Nem Jarry seria capaz de supor que entre nós, desde sempre, na prática a teoria é outra.

É evidente que a "caótica" situação política do país contribuiu para a formulação da poética do caos em LP, mas é igualmente evidente, pelo desenvolvimento narrativo do próprio romance, que o autor, por fim, fez valer sobre o caos a dimensão profunda e existencial do narrador-personagem, redimindo, mesmo na sua crise, o humanismo psicológico do realismo formal. Isso fica explícito no terço final do livro. Depois do longo parágrafo que descreve em detalhes a morte do pai (p. 190-211), ele próprio um grande transe interior da autoria com suas vinte e uma páginas, a escrita de LP muda e opta sensivelmente pela investigação interior do narrador-personagem: ele passa a cada vez mais fazer comentários em primeira pessoa sobre o ato de escrever (p. 212, 238) enquanto os personagens históricos, míticos, assim como as personagens femininas, caóticas, vão ficando para trás; a náusea, por sua vez, que o tempo todo parecia ameaçar o romance de seguir em frente atinge agora seu ponto crucial; e acima de tudo isso, o romance adquire a partir deste último terço uma narrativa, digamos, mais linear, ao ponto de atingir seu desfecho realisticamente: depois do enterro do pai, o narrador-personagem se pergunta sobre o que fazer da vida daí em diante... Um passeio pela cidade, carros e vitrinas, e o final dentro de um cinema. Depois de todas as aventuras e aberturas, restou a nosso herói comer bolo e tomar coca-cola com seu padrinho. A objetividade narrativa, típica daquela literatura negativa (o 'anti-romance') que via o mundo como quem vê um vaso (p. 256), acaba emoldurada, do princípio ao fim, pelo relato subjetivado do Ele. Lugar Público é, antes de tudo, um 
romance.

Ora, sei bem que não devemos esperar de uma obra de arte que ela seja mais do que aquilo que ela é, isso seria um vício da crítica, mas como aprendi com Paul Valéry devo julgar uma obra pela realização que ela faz das propostas que ela mesma, formalmente, se propôs: e é fato que Lugar Público nos toma pelas mãos para uma viagem a beira do abismo, para no final nos trazer de volta, sãos e salvos, para o lar seguro da consciência reflexionante, mesmo que cheia de angústia. O livro se constrói segundo o seguinte esquema: a dimensão existencial do narrador-personagem transpõe-se no romance sempre contrastada (e superada) por aquela "crise da representação" que procurei descrever nas muitas páginas acima; só que este embrião florescente de um "novo romance" contra a interpretação acaba, por fim, interpretado (e domesticado) por aquela tal "fadiga de existir".

Fato que não reduz a qualidade do livro, pelo contrário, até simpatizo mais com ele assim, desequilibrado, inconstante, e por fim mais conformista - justamente porque nos revela um autor lutando contra as limitações de sua personalidade e de seu tempo; mas não me nego a apontarlhe a contradição e sugerir que esse "novo romance urbano" que é Lugar Público nos mostra, nas malhas de suas indecisões formais, na sua hesitação em abraçar integralmente um projeto de ruptura radical com a tradição, para além dos dilemas pessoais do jovem autor Agrippino, o impasse da própria classe média progressista brasileira do pós-golpe: aberta para a democracia e para a liberdade, surfando na maré alta da nova etapa do capitalismo, porém incapaz de realizar por si mesma seus ideais reformistas e se ressentindo por ter sido atropelada pelos fantasmas da história. Só lhe resta então ir ao cinema, provavelmente para assistir um filme sobre os ditames da incomunicabilidade.

A grande lição que podemos tirar disso é que a criação literária possui um aspecto criativo e coletivo de acumulação. ${ }^{97}$ E se Agrippino vicejava de fato levar adiante o projeto de uma Arte Soma, e se esse projeto, conforme estou propondo aqui, será um desenvolvimento natural dessa poética do caos, caberia a ele próprio, eximidos os anseios e desesperos de um livro de estréia, dar o passo seguinte, e isso significaria: eliminar de vez a possibilidade de uma recaída num narrador 97 O "sistema literário” de Antônio Cândido. 
introspectivo; levar adiante este corpo a corpo com os mitos, com o movimento, indo além da representação, do teatro do inconsciente, mas mantendo com eles uma relação próxima, pois ignorálos significaria uma nova derrota; encontrar uma forma capaz de dar fôlego a estas singularidades não-literárias. Agrippino optará então por uma obra híbrida, entre a epopéia e o romance. Estamos a caminho da Panamérica.

\section{III}

Se em Lugar Público terminamos a história sentados, olhando fixamente para as “imagens brilhantes" do cinema, em Panamérica (1967) começamos o livro dentro da tela: num admirável mundo cinematográfico. Dentro, mas também imediatamente fora, pois o que de fato vemos são os bastidores da produção de um filme. O artifício aqui é transformar num épico a própria fatura de um filme épico, no sentido mais anglo-saxão da palavra, de algo grandioso, que envolve os destinos de toda uma nação. Este filme é intitulado simplesmente $A$ Bíblia, e a cena a ser filmada é nada mais nada menos que a "fuga dos judeus", talvez a passagem mais cinematográfica de todo o Velho Testamento. A mesma, aliás, que havia ficado famosa poucos anos antes nas mãos do mais "épico" dos cineastas americanos: Cecil B. DeMille ${ }^{98}$. Percebemos logo então que neste mundo "de

98 Diretor de Os Dez Mandamentos (1956) 
cinema", que neste jogo de espelhamentos entre dentro e fora, o que está mesmo em jogo é algo próximo daquela "mitologização dos mitos" supracitada: uma maneira de revelar-nos a câmera obscura da ideologia através de um re-ficcionalização da história. ${ }^{99}$ Tudo isso de um modo muito bem humorado.

\begin{abstract}
"Eu e John Wayne continuamos batendo os pés no corredor e entramos no depósito de barbas. Eu chamei o funcionário encarregado das barbas, que estava dormindo sentado à mesa. O funcionário acordou assustado e pedi o mostruário das barbas. Eu e John Wayne percorremos o mostruário e escolhemos a barba número 453 do século $\mathrm{X}$ antes de cristo. O funcionário correu entre as estantes onde estavam dependuradas as barbas e trouxe a barba número 453. Eu coloquei a barba em John Wayne e pedi que ele se afastasse para olhar melhor no espelho. John Wayne disse que os bigodes da barba o atrapalhavam quando ele falava. Eu pedi que ele pronunciasse algumas palavras e verifiquei que aquela barba não era possível de ser usada." 100
\end{abstract}

Para apresentarmos melhor a trama para um leitor não familiarizado com o livro de Agrippino, esclareço que nos primeiros "cantos" de PA acompanhamos as desventuras deste narrador-personagem, deste $E U$ que se nos apresenta como um diretor de cinema, dos grandes, numa Hollywood onírica, com suas estrelas, seus belos poentes e seus estúdios procriando a America em seu ventre. Neste primeiro "canto", vamos encontrá-lo no meio das filmagens de uma superprodução bíblica; é ele quem conduz um dos seus astros até o "depósito de barbas” para uma prova de figurino. Há, evidentemente, um humor kafkiano nessa abordagem da burocracia dos estúdios, nesta dimensão industrial do espetáculo, especialmente naquilo que o autor tcheco trazia também do cinema mudo, de Carlitos, dos pastelões de antanho: o funcionário que dorme à mesa, a barba $\mathrm{n}^{\circ} 453$ do século $\mathrm{X}$ procurada nas estantes, o astro John Wayne que não consegue mexer a boca (o desfecho da cena se dá bem no estilo "o gordo e o magro", com o diretor arrancando na mão o bigode de Wayne para que ele pudesse falar). Essa dimensão paródica de como nascem as fábulas dá a exata medida daquele "dentro e fora" ao qual me referia, na medida em que "a paródia permite que se fale de dentro do discurso sem ser totalmente recuperado por ele."101 É necessário, no entanto, ressaltar que mais importante que a

99 É a aposta de Evelina Hoisel; ver o capítulo "O Filme como Modelo" in: HOISEL. Opus Cit. - p. 58.

100 PA (usarei esta sigla para Panamérica) - p. 19.

101 HUTCHEON. Opus Cit. - p. 58. 
paródia $^{102}$, que por si só pode desgastar-se facilmente no clichê, é esta imediatez do humor: menos retórico que a Ironia, o humor é esse "espirro da mente" capaz de levar o leitor aquele "espantar-se consigo mesmo" que é o fundamento do caos.

Esse espanto guarda algo também do "estranhamento", do Verfremdung de Bertold Brecht. Obviamente, seria necessário todo um conjunto de obras para dar conta aqui de uma significação mais precisa desse "efeito" tal como teorizado pelo teatrólogo alemão. Há muitas maneiras de abordar a questão: podemos pensar na influência direta para Brecht da ostranenie de Viktor Chklovski e dos poetas vanguardistas russos; ou se preferirmos, investigar etimologicamente a inspiração do Verfremdung no "Entfremdung" da Fenomenologia do Espírito hegeliana, na dialética entre o Ser-em-si e o Ser alienado de si (estranhado). No caso aqui em questão, talvez seja útil lembrarmos o projeto brechtiano de um Pequeno Organon para um teatro não-aristotélico. Trata-se então de levar para a cena, para o teatro, a revolução que Bacon havia feito nas ciências (e que havia, ao seu modo, desmoronado a mundo aristotélico medieval), e a base para isso seria o "espanto" perante as coisas, no sentido de Galileu: aquele que se espanta com o óbvio e assim reconhece as leis do mundo. Vemos então que o espanto está no cerne do "estranhamento" de Brecht e é condição para o seu "teatro da era científica". E mesmo sabendo já que a dimensão do espanto em Agrippino guarda outras nuances e implicações, é importante notarmos que muitas das questões levantadas por Brecht acabaram incorporadas por um artista tão ligado ao teatro como Agrippino. Por exemplo: o estranhamento é justamente o instrumento que permite ao artista (e, consequentemente, ao espectador) estar ao mesmo tempo 'dentro e fora' da ação - como o ator que está no seu personagem, mas sempre o “distanciando"; como o movimento do espectador de, ao não se identificar com o herói, compreender a própria natureza (histórica) do movimento.

Na prática, porém, a coisa se complica ainda mais pelo simples fato de que embora teorizado nos seus escritos, esse estranhamento de modo algum foi descrito

102 Não estou certo, por exemplo, de que PA seja, em princípio, uma paródia das epopéias da tradição porque o mito ali não é um recurso de estruturação, como é no Ulisses de Joyce ou em O Silêncio das Sereias de Kafka. Trata-se sim de uma epopéia do mundo contemporâneo e, como tal, a paródia é um dos seus importantes elementos retóricos, mas não é, consequentemente, seu elemento de estruturação. 
"metodologicamente" para sua aplicação na cena: cabe assim a todo aquele que se aventura numa encenação à Brecht descobrir seus espantos, seus estranhamentos. Creio que logo neste primeiro capítulo de Panamérica encontramos esse "estranhamento" em dois recursos formais: o primeiro, no uso excessivo e reiterado do pronome $E u$ (basta uma espiada no trecho acima para notar essa repetição desnecessária); o segundo, neste "trabalho da cena", nesta exposição do trabalho, neste desnudar a obra enquanto ela é feita.

No primeiro caso, trata-se de uma insistência no uso do pronome pessoal no começo da frase mesmo quando sabemos que ele é desnecessário. Isso causa um distanciamento do leitor em relação ao sujeito da fala, pois é como se o personagem, em primeira pessoa, insistisse na sua existência também como um narrador (terceira pessoa). O que se assemelha a um dos modos sugeridos por Brecht no 'Diário de Trabalho' para o estudo do estranhamento entre os atores: fazer com que eles leiam suas falas na terceira pessoa. De qualquer modo, este $E u$ torna-se um objeto da consciência e não a própria consciência. O que muito nos diz sobre o chamado "teatro épico": justamente aquele que recoloca a questão do narrador, transformando o ator (e o personagem) em narradores do seu próprio drama, evitando a purgação terapêutica em seu mythos ${ }^{103}$ (lembremos como Mautner escreveu sobre seu desejo de purgar os mitos e percebamos aqui a diferença), e obrigando-os a confrontar sua existência no mundo, na história (veja como essa dimensão, por sua vez, é a inspiração para Barthes e seu desnaturalização semiótica, o que não deixa de ser um tipo de estranhamento, das mitologias que dão sustento e forma a ideologia burguesa). Percebemos então que o Épico em Agrippino tem muitas camadas.

No segundo caso, temos o cinema visto como um fenômeno econômico, onde

$103 \mathrm{Na}$ Poética de Aristóteles, o mythos é a disposição dos fatos num sistema, a tessitura da intriga. Ele é o esquematismo da função narrativa, aquilo mesmo responsável por engendrar uma inteligibilidade entre o "tema", o "pensamento" da anedota e a apresentação das circunstâncias, dos caracteres e dos episódios que constituem a obra. Paul Ricouer levará essa definição mais adiante ao propor que só pelo mythos organizamos nossa experiência temporal, ele é aquilo que dá forma as sensações do sujeito ante o tempo. Ele chama ainda a atenção para a proximidade dos termos mythos $e$ mimesis. Ora, sabendo que a mimesis basicamente é a capacidade de compreender que "este é aquele", o estranhamento no mythos é aquilo que constitui o sujeito ante o tempo histórico na medida em que propõe por princípio o "este é aquele historicamente". A inserção da "voz épica" (narração) brechtiana desnaturaliza a ordem supostamente cósmica (Logos) que interessa a imitação da ação elevada, substituindo uma teoria do conhecimento (lógica formal), fundamento da mimesis aristotélica, por uma história social do conhecimento ("lógica dialética"). 
feita a contabilidade da cena (helicópteros explodidos, cenários destruídos, centenas de figurantes mortos e feridos) o importante é que a tomada "valeu" - daí o encontro no final em que o produtor chega no set e dá um belo abraço no diretor convidando-o para o almoço. Esse contraste entre um espetáculo grandiloquente (o mar de gelatina verde, grandes astros do cinema dependurados em cabo metálicos, uma grande nuvem de fogo provocada por um lança-chamas) e o funcionamento mais autonomizado, mais econômico, da produção (e esta é uma palavra-chave) explora as contradições entre o imaginário e o material, ao gosto brechtiano, cujo interesse sempre recaí sobre a "realidade" (da forma) e não sobre o realismo. Importante observar também que mesmo passado este primeiro canto, a autonomização continuará a ser traduzida em ação narrativa: na separação emoldurada dos capítulos, nas frases potencialmente autônomas de uma narrativa e de um sujeito. É a reificação como tendência literária típica do modernismo (a fragmentação que gera uma autonomia das partes contra o todo): resgatar o humano através do inumano.

Pois é a partir dessa imensa fábrica produtora de mitos, Hollywood, que reproduz, por sua vez, o maior compêndio de mitos de nossa tradição, a Bíblia (e lembremos que toda nova versão é o mito), que somos introduzidos nessa epopéia. Este primeiro movimento, aliás, funciona como uma invocação: assim como as musas concedem ao poeta o dom das palavras, o cinema concede ao escritor o dom das imagens. No início era o verbo: "ação!" - eis o evangelho na Era da Comunicação (onde as singularidades não-literárias transformam a literatura, pelo menos em parte, numa soma épica de performances). Parece-me, portanto, um começo natural já que, conforme analisado páginas atrás, a lógica da escritura de Agrippino, inspirada em Mautner, nos remete aquela escrita pobre e lacunar típica do Velho Testamento. Só que Mautner nunca se interessou totalmente em escrever algo como uma Epopéia. Talvez uma nova breve comparação nos esclareça os motivos.

\footnotetext{
"Esta certeza clara do fim, da inutilidade! Esta certeza obscura do fim, esta sensação, somente sensação, intuição que vem do meu caos profundo e que prenuncia a tempestade. Que venha a tempestade. Quero senti-la. Deve ser uma tempestade negra, enorme nuvem de chuva, matarás! (...) 'Aqui existe o nada'. Digo eu: 'e o nada é muita coisa: é tudo. É a tragédia, o teatro, o teatro, o teatro." 104
}

104 DCM - p.80. 
A metafísica de Mautner é uma estética. Ele parte de Heidegger, "somente na clara noite do nada da angústia surge a originária abertura do ente enquanto tal: o fato de que é ente e não nada", ${ }^{105}$ mas rapidamente se afasta do filósofo alemão em direção a dimensão teatral da tragédia. Essa postura trágica da obra de Mautner, e de Glauber, é o que os afasta da épica de Agrippino, na medida em que o trágico depende:

“...principalmente de que o formidável - como Deus e o homem se acasalam, e como, ilimitadamente, o poder da natureza e o mais íntimo do homem unificam-se nessa ira - seja concebido pelo fato de que a unificação ilimitada se purifica por meio de uma separação ilimitada."106

O trecho citado por Szondi pertence a Holderlin e resume bem a concepção do trágico que perpassou todo o idealismo alemão: é pela perda da liberdade que se prova justamente esta liberdade. O herói trágico luta contra seu destino e acaba sempre sucumbindo a este, mas maior que a morte é a punição que ele recebe, a prova de que a vontade de liberdade constitui a essência do seu ser. Este fracasso, esta separação ilimitada, é aquilo mesmo que purifica a unificação ilimitada. A tragédia é a forma literária que, percebendo a queda inevitável, a dimensão irreconciliável entre natureza e cultura, procura dar uma resposta a pergunta: como pode então a vida tornar-se essencial? 107 Daí um personagem como Paulo Martins de Terra Transe manifestar sua famosa "fome de absoluto" (que inclusive, à época, foi considerada um traço de fascismo) e afirmar sem meias palavras que sua morte significava o "triunfo da beleza e da justiça" sacrifício e a dialética adquire assim uma feição trágica, kaótica, onde o transe, o movimento, a passagem, é o salto sobre a separação consumada (homem e mundo; palavra e coisa; mito e história).

Tanto em Glauber quanto em Mautner, e de fato em quase toda a tragédia

105 HEIDEGGER. Que é Metafísica? - p. 35.

106 SZONDI. Ensaio sobre o Trágico - p. 35.

107 LUKÁCS. A Teoria do Romance - p. 32.

108 É preciso levar em conta, no entanto, que o estilo "indireto-livre" de Terra em Transe desmascara o idealismo do personagem na medida em que nos apresenta, dialogicamente, duas visões do personagem: o transe interior (seu delírio trágico) e o transe exterior (as imagens que constroem o filme e que nos revelam sua "vontade de poder"). Nesse sentido, embora Paulo Martins possua essa dimensão trágica (especialmente do seu ponto de vista), essa visão não é corroborada pela estrutura do filme, que nos "distancia" dos seus delírios. Sobre o assunto, ver o capítulo sobre Terra em Transe in: XAVIER. Alegorias do Subdesenvolvimento. 
moderna, o processo trágico não está tanto no fatum, nas forças superiores do destino, mas é a própria existência humana que é trágica: ela não suporta o eterno ao qual fomos destinados. É um dos temas favoritos de Goethe: "a dialética trágica mostra-se no próprio homem, em quem o dever e o querer tendem a se afastar e ameaçam romper a unidade do $\mathrm{Eu}(. .$.$) Trágico não é o banal de querer o que$ não deve ou de não querer o que deve, mas de precisar querer o que não tem o direito de querer." 109 Mas há, e isso também é importante observar, muitas nuances nesse processo: no caso da obra de Glauber, por exemplo, as forças do fatum ganham um tom alegórico, figural, em que os personagens (e o autor) evocam o transcendente no seu próprio desejo de história. É a dimensão messiânica do sertão-mar ${ }^{110}$. No entanto, o importante aqui é fixarmos um ponto: a tragédia é a unificação ilimitada, a vontade de liberdade, purgada na separação ilimitada, na punição e na perda da liberdade.

Assim, posso afirmar categoricamente: na obra de Agrippino não encontramos qualquer vestígio significativo do trágico, a menos que reconheçamos, e aqui voltamos a tautologia, que o trágico não é a impossibilidade do todo repetidamente purgada pelo herói, mas a necessidade dessa repetição. De fato, especialmente em Panamérica, Agrippino se lança mais na direção da Comédia, já que, conforme a frase lapidar atribuída ao dramaturgo inglês Christopher Fry, "na tragédia, cada momento é a eternidade; na comédia, a eternidade é um momento" - algo que evoca vagamente, eu penso, a comparação que fiz entre Mautner (o múltiplo no Uno) e Agrippino (o Uno no múltiplo). Mas voltemos a pensar a questão da “epopéia” em Panamérica.

Sugiro ao leitor que releia o trecho de Mautner logo acima citado. Vais encontrar uma escrita circunscrita aos seus clichês temáticos, mas sempre muito afetada e pregnante, no sentido ulterior da expressão: grávida de sentido. O bardo clama pelo "caos profundo" que “prenuncia a tempestade”, esta "certeza obscura do fim" - aí vemos perfeitamente como a morte é o mythos, a trama arquetípica, do trágico. Já em Panamérica:

"Nós dois estávamos imóveis encostados à parede, eu não me recordo quanto tempo, mas nós estávamos abraçados e encostados ali há muito tempo. Eu não me recordava se eram horas, dias ou meses. Nós dois

109 Citado em SZONDI. Opus Cit. - p. 49.

110 XAVIER. Sertão-Mar: Glauber Rocha e a Estética da Fome (ver bibliografia) 
esquecemos que naquele momento nós pretendíamos a paz dentro da violência do mundo, e sem perceber a chegada da paz nós dois estávamos alojados dentro dela. Nós não saímos da parede e a paz nos encontrou subitamente, não enviou nenhum sinal, e nós não procuramos a paz. Ela tirou o vestido e eu disse que ela deveria ter... Eu e ela nus. Quando terminar o fim do mundo nós iremos para qualquer lugar."111

Neste trecho do quinto canto de PA, surpreendemos o "diretor" e sua namorada, Marylin Monroe, entre quatro paredes. O que temos aqui? Em primeiro lugar, resta-nos a certeza de que o inevitável nesta trama arquetípica, não é mais a morte, como o autor deixa bem claro, mas sim a ressurreição (a repetição). ${ }^{112}$ Em segundo lugar, estilisticamente, a prosa de Agrippino é muito mais rarefeita, sem lirismos, que a de Mautner: a paz chega, os encontra subitamente, sem nenhum sinal e sem que ninguém a procurasse. Mas aquilo mesmo que define o romance não é o fato de que seus personagens buscam algo? Pelo menos foi o que nos ensinou Lukács. Ora, sabemos que os romances modernos, como meta-romances, tomaram gosto por personagens que não parecem buscar nada (talvez por isso Lukács tenha apontado Tolstoi como o limite do romance e Dostoiévski já como outra coisa). Só que esse vazio existencial era ainda neles contrastado por uma pujança da forma, do estilo de escrita romanesca (levada aos seus limites). Agrippino, assim como Mautner (e isso é o fundamental que os une), escreve já "não-romances" com a frieza e o humor dos filhos da bomba atômica. Neles, o realismo formal é apenas uma nuvem pálida pairando no céu da civilização burguesa.

Juntos nessa batalha vanguardista e underground por uma outra poética, mesmo sem abandonar inteiramente (e como poderiam?) a natureza do romance - cuja característica fundamental é justamente descobrir e construir pela forma a totalidade oculta da vida ${ }^{113}$ - eles se separam na 'qualidade' do texto. O gosto pela frase mais grave, mais estilizada, leva Mautner a suprimir de sua prosa, com frequência, a leveza - mesmo quando a cena nos parece suave, a retórica de Mautner (barroca, como já vimos) a pinta com tintas excessivas, berrantes. Por outro lado,

$111 \mathrm{PA}-$ p. 61

112 Não a Ressurreição que Northrop Frye atribuía ao mythos da Comédia, o anagnorisis (um dos quatro radicais de todas as histórias possíveis), mas uma ressurreição sem triunfos, nem complexos - rumo ao porvir.

113 LUKÁCS. Opus Cit. - p. 60. 
Agrippino faz questão de suprimir de sua prosa todo o peso (se o "fardo da existência" do protagonista ainda aparecia ruidoso em LP, em PA ele está, por princípio, excluído). E é justamente dessa forma que Lukács distingue a tragédia da épica: o trivial para a esfera da vida (aquilo que deve ser suprimido) "para a épica, é o peso, assim como era a leveza para a tragédia". ${ }^{114}$ A tragédia, como vimos, oferece uma resposta a pergunta: como a vida pode tornar-se essencial? Ou seja: ela é uma arte cujo objeto é a essência, a reconciliação com a totalidade; a épica, por sua vez, não tem por objeto uma essência, mas apenas a vida. Sua harmonia é preestabelecida: “o próprio processo pré-literário de uma abrangência mitológica de toda a vida purificou a existência de qualquer fardo". ${ }^{115}$ Com seu sentimento trágico, Mautner desenhou para si uma metafísica transcendente em direção ao kaos; com sua epopéia contemporânea Agrippino rascunhou uma "metafísica" imanente em direção ao caos.

Como Brecht, Agrippino evitou a tragédia, que de alguma forma perpassa ainda toda a estrutura do drama, como modo de impedir uma subordinação da vida a uma essência idealista. Restou-lhe, como vanguarda do anti-romance, uma obra híbrida, entre o romance e a epopéia: romance porque, como uma cria da vida moderna, ela busca algo, pois entende a totalidade como fragmentária; epopéia porque essa fragmentação só pode conduzir a uma imanência do sentido à vida, atual e presente, na medida em que se o vínculo do homem com o mundo se perdeu, se já não acreditamos mais nele, só nos resta acreditar nesse mundo - esse é o nosso novo vínculo, uma crença nesse mundo. Aqui reencontramos o tema discutido por mim no inicio da parte I deste trabalho: Agrippino afasta-se do Velho Mundo, e seu comprazer-se na decadência do espírito, e se aproxima das vanguardas não-teológicas da América, menos até no seu pragmatismo e mais nessa crença na carne, na capacidade de se atingir os sentidos antes dos Sentidos. ${ }^{116}$

"Eu passei óleo de bronzear em Marylin, e depois deitei ao seu lado. A minha cabeça estava inclinada e eu via o rochedo como uma enorme massa de carne imóvel se introduzindo na água do mar. A espuma branca

114 Idem - p. 56.

115 Ibidem - p. 57.

116 A época da escrita de Panamérica, Agrippino já havia tido contado, no atêlie do artista José Roberto Aguilar, com o grupo de dança contemporânea Móbile, especialmente com Maria Esther Stockler que chegara recentemente de Nova Iorque muito entusiasmada como os ensinamentos da coreógrafa Martha Graham e com as montagens do Living Theatre. Considero assim Panamérica um livro que já partilha a atmosfera de criação do grupo teatral Sonda que no ano seguinte realizaria o filme Hitler $I I^{\circ}$ Mundo e logo em seguida o espetáculo Rito do Amor Selvagem. 
explodia para o alto e salpicava de pequenas gotas o dorso imenso da pedra. A água corria entre as pedras e se distribuía entre os vãos, e escorria fervendo para o mar (...) Depois o rosto de Marylin Monroe estava muito próximo do meu e a pele branca irradiava a luminosidade do sol. Eu vi muito próximo dos meus olhos o nariz, a boca, os dentes, os olhos, os pelos da sobrancelha e os poros. O rosto era recortado pela luz azul e brilhante do céu. Ela movimentou a boca lentamente e eu vi os dentes aparecendo, a língua e depois os lábios se fecharam. Eu sentia a mesma desproporção da natureza, e o rosto de Marylin Monroe iluminado pelo azul do céu, e eu via as dimensões gigantescas da boca, do nariz e dos olhos."117

Durante todo o quinto canto de $\mathrm{PA},{ }^{118}$ acompanhamos num quarto fechado as relações físicas entre o diretor e sua namorada Marylin Monroe, em sucessivos quadros de enlace e sexo que acabam por culminar na cena descrita no trecho logo acima. Nessa encenação de corpos a procura de sensações, conforme já analisado em LP, descobrimos que muito mais do que uma utilização "desconstrutiva" e crítica dos mitos da cultura de massas, trata-se aqui de trazê-los, de experimentá-los, de modo mais perto do corpo, da terra, como um primeiro verme a roer a carne dos deuses. Evelina Hoisel já apontou muito bem que PA "realiza o que num outro nível as demais artes realizaram, apropriando-se do corpo como um signo capaz de tensionar o ambiente" ${ }^{119}$, provocando assim um alargamento da percepção. No trecho acima, por exemplo, o narrador nos convida a uma viagem "objetiva" pelo corpo de Marylin (com direito a primeiro plano e mudança de foco) ao qual ao fundo ele contrapõe o rochedo, a natureza (a paisagem). Temos então a retaliação do corpo orgânico em nome de um outro corpo cujo olhar é imenso, que não é humano, mas um olhar das próprias coisas: a montagem. É o cinema como um horizonte imediato que tenciona a escrita literária como a típica e ulterior manifestação do diabo (por definição, aquilo que vem para separar e não unir - a crença na separação), conforme escreveu Jean Epstein:
"O primeiro plano lavra um outro tento contra a ordem familiar das aparências. A imagem de um olho, mão, boca, que ocupe toda a tela - não apenas porque ela é ampliada trezentas vezes, mas também porque a vemos isolada da comunidade orgânica - reveste-se de uma espécie de

\footnotetext{
$117 \mathrm{PA}-$ p. 67.
}

118 Se considerarmos o poema épico por excelência, a Odisséia de Homero, veremos que cada uma de suas partes é identificada como "odisséia" seguida de um caractere grego, ou seja, o Epos (o Canto) é uma organização de cantos. Cada um deles não é inteiramente redutível ao todo, dispondo com ele de uma relação dialética, daí minha preferência por chamar cada uma das partes de Panamérica de "cantos" e não "capítulos", na medida em que o capítulo, no sentido arcaíco-clerical da expressão, é justamente aquele que "capitula" perante uma ordenança.

119 HOISEL. Opus Cit. - p. 36. 
autonomia animal. Esse olho, esses dedos, esses lábios, já se tornaram seres que tem seus próprios limites, seus movimentos, sua vida, seu próprio fim. Eles existem por si mesmos (...) No fundo da íris, um espírito forma seus oráculos. Esse olhar imenso, gostaríamos de tocá-lo, não fosse carregado de tanta força perigosa. Já não é mais fábula o fato de a luz ser ponderável. No ovo de um cristalino, transparece um mundo confuso e contraditório no qual adivinhamos o monismo universal da Mesa de Esmeralda, a unidade do que se move e do que é movido, ubiquidade da mesma vida, o peso do pensamento e a espiritualidade da carne (...) Nos gestos, mesmo nos mais humanos, a inteligência se apaga diante do instinto que, sozinho, pode comandar jogos de músculos tão sutis, tão nuançados, tão absolutamente certos e felizes (...) Muitas da classificações rigorosas e superficiais que atribuimos a natureza, não passam de artifícios e ilusões. Sob essas miragens, o povo das formas revela-se essencialmente homogêneo e estranhamente anárquico." ${ }^{20}$

Penso, portanto, que o fundamental aqui é percebermos que esse "olhar imenso" das coisas nos esclarece um ponto chave: a crença neste mundo é uma fé que restitui o discurso ao corpo, mas não simplesmente um corpo físico, material (e repito aqui o que já disse páginas acima) mas o corpo entendido como uma abertura, como um novo nascimento para e com o mundo, como o descobrir-se um espaço não aprisionado pelo ente. É esse não aprisionamento, essa vertigem, esse "peso do pensamento e da espiritualidade da carne" que leva o diretor a nos relatar diante da dimensão gigantesca de Marylin: "senti a mesma desproporção da natureza”. Ele sente, ao modo do juízo kantiano, a desproporção estética entre homem e natureza, mas há um traço peculiar no seu relato: não é que ele sinta a mesma desproporção em Marylin e na natureza, mas ele sente a mesma desproporção da natureza no corpo de Marylin tal como visto por esse olhar das coisas. Pois então não se trata de uma estética do sublime, onde o sujeito se enche de terror diante da imensidão da natureza, mas sim da natureza (no sentido de Bazin, de que a "objetiva" da câmera é uma realização técnica "natural") que olha de volta para si mesma como esse espanto de um corpo inumano e inorgânico. A Arte Soma é a busca por esse corpo que só pode ser encontrado quando o povo das formas revela-se ao mesmo tempo homogêneo e estranhamente anárquico (ou seja, como singularidades).

Cientes desse fato, nos encaminhamos para a segunda parte de Panamérica. Explico: como sugere o solitário estudo de Evelina Hoisel, podemos dividir PA em três blocos - do canto I ao VII, o caos estadunidense; do VIII ao XI, o caos latino-americano; do XII ao XX, um 
híbrido, o caos pan-americano. ${ }^{121}$ No derradeiro canto da primeira parte, o canto VII, nos deparamos então com o gigante mitológico Joe Di Maggio, que nos é apresentado numa cerimônia suntuosa (ele entra carregado por dez negros eunucos e traz nas mãos um capacete dourado e uma foice de prata) apresentada num estádio de beisebol completamente lotado de gente. Aos poucos, a partida esportiva se transforma numa explosão de fúria em que Di Maggio (adquirindo proporções descomunais) passa a decepar cabeças com sua foice, exterminando todos os espectadores e derrubando o estádio a pontapés. Para além desta encenação do furor mítico que envolve esses grandes espetáculos de massas que são os esportes na Era da Comunicação, Di Maggio (que na "vida real", como sabemos, foi o principal nome do beisebol americano no seu tempo e marido de Marylin), aparece na narrativa como um tipo de "antagonista": o símbolo do poder imperial Ianque com seu grande falo de dois metros de cumprimento que contrapõe-se ao narrador, a "personificação mitológica da América Latina", conforme escreveu Mário Schenberg no prefácio a PA. Pois bem: não estaríamos aqui diante de um teatro do inconsciente latino-americano, com direito a todo um imaginário psicanalítico da luta entre opressores e oprimidos? Em certo sentido sim. Como eu havia dito no final da parte II, Agrippino mantém uma relação com esse teatro da memória coletiva nacional. Mas é importante notar que as formas da grande Épica, invocadas em PA, não conhecem nem a loucura nem o crime. Nelas, os conflitos e as transgressões de normas ou acarretam uma forte vingança, que por sua vez desencadeia uma guerra infinita de "vendetas", ou então "é a perfeita teodicéia, na qual crime e castigo possuem pesos iguais e homogêneos na balança do juízo universal." ${ }^{122} \mathrm{O}$ que eu quero dizer com isso? Que não podemos reduzir PA ao palco dos conflitos simbólicos entre o mundo desenvolvido (imperialista) e o mundo subdesenvolvido (colonizado): esta Panamérica não é a síntese ou o cenário onde dois mundos entram conflito, como é a Terra do Sol de Glauber, ou mesmo o Brasil redivivo (coração do kaos) de Mautner, mas configura-se como uma desterritorialização épica desse espaço. O III $^{\circ}$ Mundo de Agrippino, como veremos, é o delírio do $3^{\circ}$ Mundo da arte nacional-popular.

Para tanto, basta pensarmos na figura do narrador: nos sete primeiros cantos de 121 HOISEL. Opus Cit. - p. 64-78.

122 LUKÁCS. Opus Cit. - p. 61. 
PA, quando o reconhecemos como o diretor de cinema, ele de modo algum se apresenta como a personificação mitológica da América Latina, como queria Schenberg. Somente no oitavo canto vemos sua transformação em soldado de um país descohecido que está sofrendo uma invasão do exército americano. O protagonista transmutou-se, assim como a cena. As perguntas, então, são inevitáveis: A trama é a mesma? Existe uma urdidura geral de enredo? Quanto ao foco narrativo, será a mesma primeira pessoa de antes? Nada permitia ao leitor, de fato, afirmar até então a continuidade do mesmo narrador-protagonista a cada novo canto, nada além de um certo "lugar comum" (Hollywood). Agora, no entanto, a ruptura com esse lugar parece definitiva. A figura que “identificávamos" como sendo o 'diretor de cinema', sem mais, torna-se um aspirante a soldado; desaparecem igualmente os outros personagens, aqueles com os quais "organizávamos o mundo". Todas as migalhas que havíamos reunido como nosso universo de referências se esvaem.

Mesmo quando nos segmentos posteriores do "romance" alguns desses lugares e personagens forem recuperados pela trama, uma certeza permanecerá: a de que nunca nos recuperamos dessa ruptura, fato que espalha uma suspeita por todo o texto - estamos diante de um livro sem sujeito nem objeto, um livro em que já não tem qualquer importância dizer ou não dizer Eu. Esta estratégia é o que permite a Agrippino evitar uma recaída no romance instropectivo. Desse modo, uma questão torna-se evidente: se não há um sujeito ou objeto, como pode haver conflito? Como pode haver antagonistas e protagonistas? Agrippino pode até evocar, como de fato faz, o antagonismo entre a grande América, rica e poderosa, e uma outra América, mais frágil e pobre, num teatro de revoluções. Só que essa alteridade não aparece tanto como oposição, como negação, mas sim como uma exterioridade pura. Talvez o que Mário Schenberg quisesse enfatizar quando chamou o narrador de "personificação da América Latina" fosse que a narração, como aspecto formal da obra, pode cumprir esse papel de combate, de vanguarda, na medida em que a Épica é sempre a expressão da verdade de um povo. É no modo como se conta que descobrimos o ser da obra. Nestes tópicos sentimos a grande inspiração de Agrippino para compor sua epopéia, a caracterização do gênero nos Cursos de Estética de Hegel: 
“... pergunta-se se aqueles poemas (homéricos) são cada um por si mesmos um todo épico orgânico ou, tal como agora é difundida a opinião, são sem início e fim necessários e, por isso, poderiam ter sido continuados ao infinito. Sem dúvida, os cantos homéricos, em vez de serem de conexão condensada, tal como as obras de arte dramáticas são, segundo a sua natureza, de uma unidade mais solta, de tal sorte que cada parte pode ser e parecer autônoma, e muitas intervenções e outras modificações permanecerem abertas; eles compõe, contudo, inteiramente uma totalidade épica veraz, inteiramente orgânica, e um tal todo apenas um único pode fazer." 123

Esse único (o grifo é dele) é o poeta. Para Hegel, o poeta épico expõe objetivamente "um mundo em si mesmo fundamentado", atemporalmente pleno e universal, e sabe-se sempre idêntico com este mundo. Sua obra de arte, no entanto, permanece a "audácia do livre criar", o produto livre do indivíduo - "devido à objetividade do todo, porém, o poeta como sujeito deve retroceder diante de seu objeto e desaparecer no mesmo. Apenas o produto, mas não o poeta parece e, todavia, o que se expressa no poema é algo seu." ${ }^{124}$ É justamente esse movimento entre o universal (o mundo) e o particular (o poeta) que permite a poesia apresentar "a totalidade desenvolvida do mundo espiritual diante da representação interior". ${ }^{125}$ Resumindo, para os fins desta dissertação: a ambigüidade entre os cantos, os sujeitos, e o Canto (a Narração, a Forma) em PA é, na verdade, a contradição constituinte da epopéia.

Segundo a tradição dialética, essa contradição fundamental é aquilo mesmo responsável por inventar o sujeito. Em Dialética do Esclarecimento, Adorno e Horkheimer vão analisar também a trajetória do herói épico a partir desta contradição constituinte:

"Eis aí o segredo do processo entre a epopéia e o mito: o eu não constitui o oposto rígido da aventura, mas só vem a se formar em sua rigidez através dessa oposição, unidade que é tão-somente na multiplicidade de tudo aquilo que é negado por essa unidade. Como os heróis de todos os romances posteriores, Ulisses por assim dizer se perde para se ganhar."

Decerto que a formação de um Eu idêntico (ordem racional) que nasça do sujeito polimorfo, fundamento da épica homérica e compatível com a plenitude de sentido da narrativa

123 HEGEL. Cursos de Estética IV. - p. 96 e 97.

124 Idem - pág. 95

125 Idem - pág. 84.

126 ADORNO, T \& HORKHEIMER, M. Dialética do Esclarecimento: fragmentos filosóficos - p. 56 
tradicional, não parece estar no horizonte de um romance como PA. Pelo contrário, podemos dizer que ali as "aventuras do sujeito" perfazem uma trajetória de dissolução. Retomemos então, nesse sentido, um tema central da Dialética do Esclarecimento. Adorno e Horkheimer interpretam o nostos, a viagem de regresso de Ulisses, como a imagem de um tempo histórico que se desprende do espaço (esquema do tempo mítico). Na medida em que o caminho percorrido de Tróia a Ítaca é o caminho dos mitos, essas "perigosas seduções que desviam o eu de sua trajetória lógica", tais perigos são vencidos pelo herói que se oferece quase que ingenuamente a eles, tirando "sua substância da experiência de tudo aquilo que é múltiplo", ${ }^{127}$ essa substância, esse saber, consiste a identidade do astucioso Ulisses, protótipo da razão esclarecida e do indivíduo burguês. Ao atravessá-lo incólume (impulsionado pelos remadores de ouvidos tapados, imagens já do trabalho que é tempo alienado), empurrando os demônios (da natureza) de volta para o fundo das cavernas, Ulisses seculariza o espaço (as ilhas do Mediterrâneo) constituindo-o como um conjunto racional. É nesse sentido que os autores da Dialética do Esclarecimento podem dizer que o náufrago trêmulo (Ulisses) antecipa o trabalho da bússola.

Na epopéia de Agrippino acontece o oposto: é o espaço que se desprende do tempo (histórico). Isso porque não interessa ao autor a representação dialética do movimento que constitui o sujeito: o que lhe interessa é o próprio movimento na sua multiplicidade. Isso fica evidente no canto VIII já citado. Essa “outra América” que irrompe no texto está repleta de historicidade: evoca-se um golpe militar; marines desembarcam numa praia do caribe; ${ }^{128}$ tumultos acontecem nas ruas entre pescadores, operários, terroristas e soldados; comunistas tomam o poder, para logo em seguida serem enforcados por tropas do exército americano... Claro que poderíamos afirmar que os episódios anteriores também já estavam cheios de significantes históricos (as próprias estrelas de cinema não deixam de ser pessoas de carne e osso), mas para um leitor da época boa parte dos relatos contidos no canto VIII (e nos que se seguem) eram dados imediatos de sua realidade político-social. É preciso 127 Idem - Pág. 56

128 O herói, agora engajado no exército, viaja a bordo de um porta-aviões denominado Lyndon Johnson que aporta na República Dominicana. Referência direta a intervenção militar preventiva promovida pelos Estados Unidos naquele país em abril de 1965 que resultou em graves conflitos armados. 
notar, no entanto, que essa "realidade" irrompe no texto de forma extemporânea. O único tempo que

se afirma é o tempo da criação-desmanche desse espaço:

\begin{abstract}
"Eu abandonei o porta-aviões Lyndon Johnson e vi desenhada a silhueta de soldados e canhões no alto da colina, e ouvi o barulho dos tiros de metralhadora. Eu voltei e perguntei para outros soldados, que eu mal conseguia distinguir na penumbra se eu poderia passar pela estrada. Os soldados riram e responderam que era muito difícil e que a estrada era a linha de fogo, mas que eu poderia tirar o capacete e avançar com menos perigo. Eu agradeci ao grupo de soldados, retirei da cabeça o meu capacete e o coloquei debaixo do braço. Os comunistas atacavam as forças do governo e eu seria reconhecido como um dos soldados do governo. Eu prossegui caminhando na estrada escura e ouvi ao longe o estalo rápido das metralhadoras e o troar dos canhões (...) O regime capitalista e as forças do governo haviam caído e os comunistas estavam no poder. Eu saltei de alegria no meio da multidão tomei um ônibus abarrotado de camponeses (...) Eu desci do ônibus e a multidão gritava com ódio agitando os braços para o porta-aviões Lyndon Johnson, que atracava no cais. O porta-aviões levava uma multidão de fuzileiros norteamericanos em silêncio. Os milhões de capacete imóveis cobriam toda a pista do porta-aviões. A imensa quilha de ferro se aproximava lentamente do cais enquanto a multidão que se encontrava no cais gritava furiosamente contra a aproximação do porta-aviões. Eu gritei espremido na multidão irada. $O$ porta-aviões, que transportava o batalhão de marines, atracou no cais, e a multidão se dispersou em pânico. Eu balancei os pés na longa mesa de mármore do frigorífico e olhei para as altas e volumosas cabeças dos comunistas que tinham sido enforcadas depois da invasão dos marines. De capacete de aço, farda e metralhadora eu montava guarda no frigorífico sentado na laje de mármore e os meus pés estavam soltos no ar. (PA, pág. 102-103)
\end{abstract}

Chegamos a imaginar nesse trecho, por um breve instante, que o narradorprotagonista "desertou" para o lado dos rebeldes durante o desembarque do porta-aviões. Ele se alegra no meio da multidão e grita enfurecido contra seus ex-companheiros marines. Mas eis que, no momento culminante do desembarque, um corte narrativo, na passagem de um simples período a outro, revela já o narrador-protagonista como a sentinela de um frigorífico tornado morgue pelo exército. O que temos nesse trecho? Se a "deserção" se confirmasse no desenrolar da narrativa, teríamos o tempo subjetivo da personagem compactuando com o tempo da ação: o movimento afetivo do soldado que se torna povo acompanharia o movimento do levante contra a invasão militar, a história (o desembarque) se tornaria o cenário (o espaço) para o drama (ele próprio histórico). Mas com a vertiginosa reaparição do protagonista como sentinela, completamente injustificável do ponto de vista dramático, o que temos é uma interrupção no "fluxo narrativo" - tanto o tempo histórico 
quanto o tempo interno da personagem tornam-se espaço: tudo é PanAmérica. Se a epopéia homérica pode ser considerada, em certo sentido, a aventura da constituição do sujeito esclarecido e da racionalidade instrumental, PA é uma epopéia do retorno ao ainda não pensado, ao corpo dilacerado do porvir.

Ao experienciar os dois lados do front, o narrador-protagonista amortiza a dissociação e o conflito (motores da história) e repõe o esquema próprio da repetição. Sua subjetividade parece se afirmar (ele salta de alegria com a multidão), mas logo em seguida ela escorre pelas brechas do texto (percebemos que essa alegria não era uma expressão subjetiva do personagem, mas uma marca puramente objetiva, um signo no espaço). De fato, podemos dizer que a constituição do sujeito-personagem (o narrador-protagonista) é constantemente interrompida, para ser sempre recolocada. No canto final, onde se narra a "decomposição do mundo", o todo se enverga e vem pra cima do sujeito-narrador (desponta no horizonte a curvatura da terra), num vislumbre apocalíptico de 'unidade', novamente interrompido, agora pelo fim da narrativa. A escritura interrompe seguidamente o processo de formação do sujeito, impedindo assim a mitificação desse sujeito totalmente esclarecido: PanAmérica é o espaço do mundo (e do sujeito) em perpétuo renascimento.

É preciso deixar claro igualmente que esse espaço (PanAmérica) que se desprende do tempo histórico não pode afirmar-se como um espaço absoluto à maneira de grande parte da chamada literatura realista, onde predomina a substancialidade do homem (em seu meio). É famoso o comentário de Pomponius Gauricus em seu trabalho De Scultura, recuperado por Panofsky 129: “o espaço existe antes do corpo que é colocado neste espaço, o segundo (o corpo) estando por necessidade graficamente fixado no primeiro (o espaço)". Essa é a concepção prototípica da racionalidade clássica. Em PA, há uma excessiva mobilidade dos corpos, uma irrealidade do espaço que não forma um sistema coerente, mas uma soma total de coeficientes espaciais. Uma arte como soma. A arquitetura de PA não se configura como uma arquitetura de espaços, mas sim de signos no espaço. É a lógica de Las Vegas: “se tirarmos os letreiros, não existe o lugar”. ${ }^{130}$ Se tirarmos Marylin 129 PANOFSKY. La Perspective Comme Forme Symbolique - p. 129 (a tradução “explicativa” é minha). 130 VENTURI, R. \& BROWN, D. S. \& IZENOUR, S. Aprendendo com Las Vegas. - p. 40. 
correndo pelo jardim com a barra do vestido levantada, não existe o jardim; se tirarmos esse Eu que grita e esbraveja no cais junto com a multidão, não existe mais a multidão - o espaço não existe antes do signo (do corpo). PanAmérica é o mundo como totalidade espetacular ${ }^{131}$, o espaço mítico da contemporaneidade, mas não devemos nos convencer de que o livro de Agrippino se fundamente sobre uma crítica ideológica desse 'estado de coisas'. Essa processo pré-literário de abrangência mitológica de toda a vida, possibilitada pelo espetáculo, foi encarado em PA como a força viva de uma nova tradição capaz de romper a dualidade moderna das formas (altas e baixas; espirituais e corpóreas) que remeteria a dualidade fundamental entre arte e vida. Como leitor de Hegel, ele sabia que:

\footnotetext{
"A epopéia ainda exige aquela unidade imediata do sentimento e da ação, entre os fins interiores que se executam conseqüentemente e as contingências do eventos exteriores - uma unidade que em sua originalidade inseparável só existe nos primórdios da vida nacional, assim como da poesia" 132
}

Agrippino escreve desse Brasil do começo dos anos 60 que finalmente deixava de ser um país eminentemente agrário para viver um choque de urbanidade onde se constituiria uma nova "universalidade de sentir e de ver" a partir de um conjunto de símbolos comuns, próprios da cultura de massas - essa mitopoiética que "tem cunhos de universalidade porque de fato é comum a toda uma sociedade". ${ }^{133}$ Para Agrippino, a cultura de massas deu vazão (assim como para muitos outros artistas e pessoas de sua época) a um sentimento universal de querer desfrutar a vida agora, sem disposição para adiamentos ou sacrifícios, políticos ou teológicos. Daí seus elogios aos filmes de James Bond, que julgava muito melhores que os "sensíveis" rebentos da Nouvelle Vague (comentário que, por sinal, horrorizava os cineclubistas da FAU); ele aproveitou esse novo contexto como o verdadeiro transe da nacionalidade, onde a efetividade dada poderia oferecer uma conexão com certa

131 "O princípio do fetichismo da mercadoria, a dominação da sociedade por coisas supra-sensíveis embora sensíveis, se realiza completamente no espetáculo, no qual o mundo sensível é substituído por uma seleção de imagens que existe acima dele, e que ao mesmo tempo se faz reconhecer como o sensível por excelência." In: DEBORD. A Sociedade do Espetáculo - tese 36, p. 28.

132 HEGEL. Opus Cit. - p. 93.

133 ECO, U. O Mito do Superman. In: Apocalípticos e Integrados. p. 242-243. 
vitalidade originária se dela fosse expurgada toda racionalidade mesquinha. Como um ato radical, provindo da classe média urbana e universitária, PA é uma experiência que dá continuidade, em alguma medida, ao projeto moderno de arrancar as "raízes" (infectadas) do Brasil. A prosa antisentimental de Agrippino também vislumbrou, a sua maneira, uma outra objetividade em oposição ao sentimentalismo burguês, ao bacharelismo de nossas letras e ao paternalismo violento de nossos costumes. Mas seu paradigma era novo: como a raposa de Isaiah Berlin que conhece muitas pequenas verdades e não uma única grande verdade (no que difere do Ouriço), o valor estético de PA não está em ser uma grande obra - este grande mergulho na experiência humana de uma personagem, de um autor, ou de toda uma história - mas em ser muitas. ${ }^{134}$ Seu estilo já não é o "novo estilo", mas sim um estilo de utilizar estilos (a ordem da falta de ordem).

Dada a ruptura do VIII canto, onde o Eu transfigura-se em outro(s), ${ }^{135}$ temos definitivamente uma afirmação do fluxo em detrimento do esquema libidinal produção-inibição de energia psiquica; isso não significa, no entanto, que nos encaminhamos aqui para uma escrita automática a maneira de Kerouac e dos beats (aquilo que Truman Capote chamou, desaforadamente, não de writting, mas de typewritting). Aparentemente, com seus grandes blocos de escrita diagramados uniformemente sobre o papel, PA nos remete a uma prosa robotizada, uma epopéia cantada por um computador, além do mais, sua escrita redundante deixa-nos com a tentação de “clinicá-la" como um poema esquizofrenico, uma ode ao desvairio, mas é justamente a insipidez cortante de sua linguagem, sua frieza, sua plasticidade analítica na construção dos períodos e das imagens que a eleva bem além da doença infantil do "vanguardismo". ${ }^{136}$

134 Lembro que a metáfora do Ouriço e da Raposa, proposta no ensaio homônimo de Isaiah Berlin (que, só pra esclarecer, tratava das diferenças entre os estilos de Tostói e Dostoievski), foi utilizada por um grupo de artistas conceituais, em sua maioria norte-americanos, no começo dos anos 70. Esse grupo (de abordagem marxista atenta as contingências de uma "praxis" artística) radicalizou algumas das propostas vinculadas pela revista Art-Language, berço do conceitualismo anglo-americano, e fez questão de batizar sua própria publicação com o nome The Fox. Para uma apanhado geral sobre o assunto, sugiro: WOOD, Paul. Arte Conceitual (ver bibliografia).

135 Aludindo não tanto ao sentido psicanalítico e antropológico que a expressão de Rimbaud Je est un autre ganhou na tradição letrada francesa (lembremos um filme como Moi, un noir de Jean Rouch), mas talvez mais àquele grito de Artaud contra o "périplo imbecil" da formação do caráter e sua explosão num Eu que representa totalmente a multiplicidade da sua vida: "Eu, Antonin Artaud, sou meu filho, meu pai, minha mãe e eu mesmo." (excerto de Para Acabar com o Julgamento de Deus).

136 É isto que faz, na minha opinião, que Panamérica seja uma experiência muito mais bem realizada e importante que boa parte dos seus similares posteriores - verdadeiras "macumbas pra turista". É o caso, por exemplo, da Divina Comédia Brasileira, texto teatral de José Roberto Aguilar encenado apenas em 1977 como parte de sua ópera 
No canto IX de PA, já aportado nas entranhas da América Latina, o Eu da narração assume as feições de um terrorista anti-governo. Na ação que se segue (cantos X e XI), acompanharemos as desventuras deste "terrorista" primeiro pela cidade, onde tem como missão aparente explodir a embaixada norte-americana (sendo perseguido por "homens biônicos" do Dops), depois num refugío na zona rural (selva venezuelana) até se juntar a um grupo de guerrilheiros organizado por Che Guevara. O clima de tensão e o imaginário dos golpes de estado na AL são mobilizados pela escritura: as forças rebeldes ("terroristas" urbanos, guerrilheiros guevaristas) aparecem como antípodas do império americano (as reuniões na sede da ONU), mas tudo nos apresentado sem maiores "dramas", num clima fantástico de história em quadrinhos. Estamos diante de mais uma singularidade que vem estilhaçar o edificio da escrita romanesca: o cartoom, com sua ausência de uma lógica discursiva clara, expressa numa fragmentação frenética de imagens que permite ao texto lidar com múltiplas "realidades" quase que simultaneamente. E para confirmar essa nossa impressão desponta na "trama" a figura do surdo-mudo Harpo Marx como fiel aliado (pois todo herói dos quadrinhos deve ter um) do narrador.

Harpo, esse arquétipo do apetite, cuja linguagem (que é aquela do Pai Ubu de Jarry) tudo devora, é a figura que invoca o destroçamento da palavra para dela eliminar todo o incorporal, assim como a "trama" vem devorar as grandes metanarrativas da história: no exato momento em que ao narrador-protagonista é colocado um sentido (histórico) - “engajar-se” na contrarevolução (ele assassina com tiros o adido militar norte-americano) - surge junto a ele Harpo Marx, esse "não-sentido" que é a própria corporeidade. Por isso ele é sempre identificado no texto como o surdo-mudo Harpo: o que é o surdo-mudo senão aquele que transformou seu próprio corpo em linguagem? A revolução social perscruta a semântica, ou melhor, o corpo do mito:

\footnotetext{
"As balas zuniam acima de nossas cabeças, e de instante a instante explodia uma granada. Quando nós percorríamos agachados a trincheira o surdo-mudo Harpo Marx voltava em sentido contrário. O surdo-mudo caminhava tranqüilamente de cartola e buzina levando uma lata na mão
}

conceitual O Circo Antropofágico. Essa experiência, que segue o rastro de PA e das peças do grupo Sonda e que, aliás, tem como personagens Agrippino e Mautner, já se perde totalmente no pastiche esquizofrênico, essa "fala em língua morta" que Jameson identificou como o signo maior da lógica cultural do capitalismo tardio (JAMESON. Pósmodernidade e Sociedade de Consumo - P. 18). 
que ele usava para urinar. O rosto idiota de Harpo Marx demonstrava passividade, e para ele parecia que nada de grave poderia acontecer, e Harpo oscilava as nádegas para os lados e caminhava tranqüilamente de cartola, sobrecasaca amarela, buzina e harpa. Eu parei a frente de Harpo, e ele sorriu para mim dedilhando a harpa e mostrando-me a lata que ele usava para urinar, e eu olhei para dentro da lata e vi dois ou três troços flutuando na urina. Harpo vinha voltando do centro da cidade, onde granadas explodiam de todos os lados e as metralhadoras repicavam insistentes." 137

Participando de uma ação guerrilheira sob o comando de Che Guevara, eis que o narrador-protagonista se depara, no meio da trincheira, com a figura de Harpo Marx vindo no sentido contrário. A história estilhaça-se sobre sua cabeça (feito balas de metralhadora), mas ele não parece se importar muito. Seu rosto está marcado pelo 'riso horrível do idiota'. Aqui vale lembrar a célebre sentença de Anatol Rosenfeld: o palhaço é o homem que não consegue distinguir entre ser e não-ser. E se essa sentença se aplica muito bem a Harpo Marx é justamente porque ele é uma figura de "puro afeto": regressiva (ele carrega consigo suas próprias fezes, recusando-se a se livrar delas como a criança da fase anal), mas ao mesmo tempo libertária (como uma "palavra-grito" de Artaud, para quem toda linguagem é excremento, porcaria, justamente por separar-se do corpo). O palhaço tem este "não-sentido" próprio do humor, este estranhamento, este momento efêmero onde o sujeito da comicidade se percebe também como objeto. ${ }^{138}$ Com Harpo Marx, a história percebe-se não só como objeto, mas também como o abjeto - ele revela-lhe sua dimensão escatológica: como o fétido, o baixo, o corpóreo; e também, na repetição de suas pulsões, como aquilo que está fadado a destruir-se - a cultura da bomba.

Como o nonsense encarnado, "jogando" livremente pelas tabelas do livro, Harpo reforça ao leitor de PA a impressão de que a metafísica, nos anos do pós-guerra, tornara-se, no mínimo, intelectualmente suspeita. E nesse terreno espinhoso das ilusões perdidas da filosofia que surge e se instala a Arte Pop. Aqui entramos numa questão importante, pois não há um comentário sobre Panamérica que não insista no seu parentesco com a Pop. No entanto, quase nada fica esclarecido com essas comparações. Se as relações de Agrippino com a emergente cultura de massas 137 PA - p. 146.

138 SALIBA, E. T. Raizes do Riso: a representação humorística na história brasileira: da Belle Époque aos primeiros tempos do rádio. - p. 305. A citação, segundo o professor Saliba, seria de André Bazin. 
dos anos 60 já foram aqui minimamente pensadas, seu apreço pelas veredas abertas pela Pop Art deve ser esclarecido de um modo muito mais profundo do que uma simples constatação de que PA é, de fato, um discurso literário POP.

De um modo semelhante as preces de Jorge Mautner para o kaos, os "expressionistas abstratos" norte-americanos da década de 50 estavam bastante interessados nos processos ocultos da criação, na dimensão xamânica da arte. Apontado pelo grande crítico Clement Greenberg como o resultado lógico da pintura modernista e sua busca pelo específico pictórico, o abstracionismo, depois de "vencida" institucionalmente a pendenga estética contra os artistas figurativos ou realistas, começou a mostrar claros sinais de desgaste no começo da década seguinte, embora julgasse que suas conquistas no campo da representação durariam ainda mais uns mil anos, ou pelo menos o mesmo tempo que a perspectiva monocular da pintura renascentista havia durado. É nesse outono do expressionismo que desponta, por todo o globo, mas mais especificamente na Inglaterra e nos Estados Unidos, um certo conjunto de obras de natureza distinta: antes identificadas como parte de um novo humanismo que viria "salvar" o figurativo na pintura, elas seriam, depois de constatado o desengano, agrupadas sob o nome, não de todo ruim, de Pop Art. Não de todo ruim, mas, como toda denominação, problemática - especialmente por destacar a relação desse vasto conjunto de obras com a dimensão pop da cultura de consumo, com seus ícones e estrelas, quando se tratava, na verdade, de algo mais profundo (e ao mesmo tempo mais superficial): a chamada Pop Art opera, em princípio, na experiência do comum, transfigurando em arte aquilo mesmo que todos já conhecem muito bem.

Ora, não era isso o que já faziam os surrealistas com seus objects trouvés e, principalmente, um dada como Marcel Duchamp e seus ready-mades? Resposta direta: não. Dadaístas e surralistas, como bons europeus continentais da belle époque, estavam muito longe da celebração pragmática do comum. Duchamp, por exemplo, a acreditar nas palavras do ensaísta Otávio Paz ${ }^{139}$, é uma espécie de duplo de Picasso, a outra face da grande arte do século XX. Enquanto Picasso se 
afirmaria por sua intensa capacidade de "produção", praticamente percorrendo todos as práticas e estilos artísticos conhecidos, Duchamp seria o grande artista de seu tempo justamente por ter se negado a "fazer arte", por ter silenciado. Em ambos os casos, no entanto, trata-se sempre de uma certa estética, de uma certa pureza, de testar os limites da arte. Por outro lado, a Pop Art é muito mais desafectada de sensibilidade. Da mesma maneira que a filosofia só entra em cena quando a linguagem saia de férias, para lembrar uma das imagens favoritas de Wittgenstein, a arte estaria, da mesma forma, intrinsicamente conectada com a experiência humana em seu nível mais primário: a fala do cotidiano - eis o que a Arte Pop veio nos mostrar. A pergunta que os modernos faziam a arte dizia respeito a sua identidade: como tal arte lida com o problema das suas limitações em relação a representação do real? As Brillo Box de Warhol deslocam a pergunta para uma outra ordem, menos metafísica, mais analítica: por que algo é arte e não um mero objeto comum? A discussão desloca-se do debate arte $\mathrm{X}$ antiarte, em que se inseriam as vanguardas históricas, para o debate do pós-guerra entre arte X meras coisas. Este é o momento em que a arte adquire total autoconsciência de si. Assim, hegelianamente, a Pop contitui-se não como um novo estilo na narrativa da história da arte moderna, mas como o marco do seu fim. Na definição precisa de Arthur Danto: "a pop marcou o fim da arte ocidental ao trazer à autoconsciência a verdade filosófica da arte". ${ }^{140}$ Não é a arte, como experiência, que termina (pelo contrário, ela ganha uma irrestrição em suas possibilidades), mas sim o benefício de uma narrativa legitimadora que a defina como a etapa seguinte de uma história que remontaria, pelo menos, ao elogio de Vasari no século XV a figura do artista.

O mesmo Danto já havia escrito, aliás, que não se pode recorrer a reações estéticas para definir uma obra de arte depois da Pop, que este é um problema filosófico, na medida em que a produção artística contemporânea nos mostrou que fazer arte é realizar uma "representação transfiguradora" e que compreender uma obra de arte é compreender não mais a narrativa de sua técnica, mas a metáfora que ela contém. ${ }^{141}$ Uma obra da Pop, por exemplo, usa a maneira como uma "não-obra de arte" apresenta seu conteúdo para intervir propondo uma nova idéia relacionada com a 
maneira pela qual esse conteúdo é apresentado. Essa transfiguração de que fala Danto inspira-se certamente no conceito religioso de transfiguração como “adorar o comum”. No Evangelho de Mateus fica claro a acepção de adorar um homem (Jesus) como a um deus.

Em PA, que é o que nos interessa, essas transfigurações dão o tom do livro desde o primeiro canto (A Bíblia tornada ação - a carne da imagem), passando pelas personagens (personas tornadas mitos; mitos ganhando o verbo) até as pequenas organizações sintáticas: uma frase de PA nos soa sempre, na sua impavidez lírica, como se tivesse sido apanhada de uma bula de remédios ou de uma receita de bolo. Ela nunca é poética, num sentido subjetivo, pois se parece exatamente com qualquer outra frase, de tal modo que ela acaba despindo-se de evocar seu uso na língua, evitando assim penetrar no campo da memória, numa unicidade da experiência adquirida pelo tempo (o passado), já que o que se pretende é que uma frase ao surgir no texto não tenha tempo de adquirir caráter algum. Como as imagens dos mass media, essas frases pertencem a uma linguagem desumanizada partilhada por todos, num processo de impessoalidade vívida que é a tônica do mundo desterrado do pós-guerra - pensemos aqui nos trabalhos de Samuel Beckett, ou melhor, escutemos as palavras do artista que talvez melhor tenha encarnado esse momento: "aqueles que falam mais sobre a individualidade são os que mais objeções opõe aos desvios, as diferenças, e dentro de poucos anos sucederá provavelmente o contrário. Qualquer dia, talvez toda gente comece a pensar de modo semelhante. É o que parece estar acontecendo."142

PA é uma epopéia desse mundo em que toda gente começa a pensar de modo semelhante, o mundo da comunicação, e como não existe outro mundo além desse, resta-nos restabelecer nossa crença nesse mundo através dessa "adoração ao comum". Se as assemblages cubistas e surrealistas, se os ready-mades de Duchamp, tinham atuado na lacuna entre a arte e a vida, para tudo transformar em arte (ou antiarte), um pintor como Jasper Johns, com sua bandeira dos Estados Unidos composta com piceladas inteiramente regulares e padronizadas, tornou essa lacuna digna de uma adoração em si mesma, já que a pergunta se aquilo era uma bandeira ou uma pintura 142 Citado em LIPPARD (org). Arte Pop - p. 101. 
tornou-se irrelevante. Aqui podemos inverter, de certo modo, a famosa provocação de Matisse com seu ceci n'est pas une pipe pois o que o quadro de Johns nos repete insistentemente é que aquilo de fato é uma bandeira. Como o símbolo augusto da nacionalidade, a bandeira não possui uma existência concreta para além das suas representações - toda reprodução da bandeira é, por excelência, a bandeira. Por isso o quadro de Johns é ao mesmo tempo a idéia (no sentido de que uma nação é uma comunidade imaginada), a coisa (a bandeira) e a imitação da coisa (a pintura da bandeira)! A arte, ao perceber-se espantada como uma "anedota gramatical", a maneira da filosofia, define para si a tarefa de conhecer filosoficamente o que é a arte.

A Pop Art é, portanto, para Agrippino muito mais do que uma inspiração temática ou estilística: ela é o paradigma do contemporâneo, de uma arte sem história da arte, desmaterializada, impura ${ }^{143}$, não necessariamente vinculada às especificidades do seu meio. Uma arte híbrida onde os artistas não seguem uma linha única de criatividade, mas intervém de muitas formas, as vezes com sua própria personalidade, no espaço da vida comum. Não é preciso muito mais para percebermos o quanto o projeto de uma Arte Soma deve a este paradigma. ${ }^{144}$ Diante da morte da metafísica e do fim da estética universal, permanece agora a arte como a soma (e a subtração) sempre aberta de fragmentos (e de sentidos) que subsistam como tal.

É seguindo essa trilha que no terço final de PA, a mistura infernal dos cenários e das personagens (assim como as fraturas na continuidade semântica do texto) se acentuam. O triângulo formado pelo narrador, Di Maggio e Marylin desfila suas peripécias de modo cada vez mais nômade e anárquico deixando evidente que o palco dessa encenação é sempre o mesmo - esta Panamérica que só pode ser a soma de todos os seus fragmentos, mas não um espaço totalizado. Agrippino parece assim cada vez mais, nestes cantos finais, privilegiar as interrupções e os acidentes da ação, algo bem típico do espírito dos happenings e da filosofia sonora zen de John Cage com suas

143 Lembro aqui que para Greenberg pura era a arte moderna, no sentido kantiano do termo, de uma arte que reflete através da arte sobre ela mesma (como faz a razão pura sobre a razão).

144 Quando me refiro ao termo paradigma penso nos artistas conceituais da revista Art-Language que se apresentavam como leitores de Thomas Kuhn e seu famoso livro A Estrutura das Revoluções Científicas para explicar como aquilo que eles faziam era o desenvolvimento de um novo paradigma que havia sido gestado no seio do modernismo e que agora dominava inteiramente a esfera artística. 
peças musicais, segundo sua própria definição, se constituindo de sons escolhidos e de sons acidentais. Esta postura está explícita em Nações Unidas, texto teatral de 1966, em que Agrippino descreve numa nota explicativa para futuros encenadores o modo como pensou sua dramaturgia: “chamo de cena a unidade de cenário, personagens e situações; e de interrupção a uma ação acidental, vinda do exterior, que perturba, confunde, destrói e desintergra a cena." ${ }^{145}$ Fica claro ali que o grupo Sonda idealizou o teatro como uma soma ritualizada de ações e acidentes, onde a supremacia do texto escrito deveria dar lugar ao acaso prefigurado. Nele, a destruição do signo é o intervalo para o nascimento do corpo, como nas famosas palavras de Rauschenberg (não por acaso, dos pintores Pop o mais influenciado por Cage) de que seu desejo era trabalhar "entre a vida e a arte" já que nenhuma delas podia ser reproduzida. O corpo é essencialmente aquilo que não pode ser reproduzido, nem representado (embora o tema da corporeidade física seja importante para sua concepção): é o estampido que irrompe nos interstícios (e nos intestinos) do pensamento (e da vida).

Por fim, pode-se dizer que a ação central de Panamérica termina no canto XVIII, com o duelo dos gigantes Joe Di Maggio e Carlo Ponti pela supremacia da indústria cinematográfica no globo. Na crise do modo de produção dos grandes estúdios, independentes como Ponti puderam dar as cartas no mundo dos filmes, no exato momento em que Cinecittá parecia de fato capaz de sobrepor a hegemonia norte-americana, inclusive na fatura do mais americano dos genêros: o western. Para tanto, em PA o gigante Ponti se alimenta do leite que jorra das tetas imensas de Sophia Loren (sua esposa), da mesma forma que Di Maggio se alimentava do corpo de Marylin.

Como a mais pop e consumível das figuras de PA, Marylin também é a mais coisificada, tomando com frequencia as feições de uma máquina de reproduzir e realizar desejos, a começar pela imagem da página 62 de PA onde o narrador escreve: “eu rasguei com a unha a tampa de papel que era a virgindade de Marylin, a tampa de papel estava pregada nos bordos do sexo de Marylin onde não existiam pêlos.” A fruição erótica do corpo de Marylin encontrada ainda nos cantos iniciais de $\mathrm{PA}^{146}$ vai dando lugar no terço final do livro a uma fruição "produtiva", maquinal do seu 145 Citado em HOISEL. Opus Cit. - p. 124.

146 "No momento em que ela subia e eu a acompanhava conversando a respeito da casa, todos os atores, atrizes, garçons e 
corpo: ela se torna, por exemplo, uma máquina-útero de proproções gigantescas capaz de produzir um “exército de fetos” (p. 217) que entrará em guerra contra as tropas unidas de Di Maggio e do narrador (até que eles consigam “negociar uma paz”). A gravidez que Marylin contraíra poucas páginas antes (p. 215) - e que havia dado um filho ao narrador, numa cena idílica digna de Mautner em que aquele, logo após o parto, envolve o corpo de Marylin num carinhoso abraço com direito a beijos no rosto e a figos frescos como aperitivo - logo fugira ao controle, espalhando pela cidade uma horda de fetos devoradores de gente. É o pesadelo da maquinação, do desregramento produção/consumo, o fantasma do surto industrial, da técnica. Não é a toa, portanto, que a imagem de Marylin esteja igualmente ligada nestes cantos últimos a "pulsão de morte" - ao todo, ela morre três vezes nas partes finais do livro: uma vez com um tiro de Di Maggio (p. 164); outra na praia, vítima de uma "arraia gigante" (p. 182); e mais outra num susposto suícidio (p. 187). Só que essa repetição, ao tornar a morte apenas uma das dimensões do possível, reforça o desprezo do livro pelo "corte psicanalítico" (a redução das repetições a complexos) e o seu apego ao fluxo: como já dito, só lhe interessa a ressurreição.

É desse modo que leio este ponto culminante da narrativa que é o confronto entre os dois gigantes. Reunidos em Wall Street, na Bolsa de Valores, os dois se enfrentam num duelo decisivo, cada um defendendo as suas ações (Carlo Ponti: Cinecittá; Di Maggio: Hollywood). As regras: ambos devem comer o maior número de bois que conseguirem, ininterruptamente, perdendo aquele que vomitar primeiro (só para constar, conduzida por cowboys, a manada de bois que adentra o recinto da Bolsa chega a 4773 cabeças). A cena evoca o "Inferno de Wall Street” de Sousândrade, especialmente naquilo que este invoca do imaginário dantesco: Dante havia conseguido de maneira astuciosa preservar a totalidade espontânea do ser da epopéia, numa época em que ela não mais era possível, ao transplantar sua ação para um outro mundo, que não era o dele, mas que ao mesmo tempo seria de todos, pois tratava-se do universo medieval cristão do após-vida. Sousândrade faz o mesmo, surpreendendo a realidade ao conduzir seu herói para um outro mundo, que não era o dele, mas que ao mesmo tempo seria de todos: Wall Street - a fonte de toda criação/destruição da moderna sociedade

convidados olharam para seu corpo lindo e firme que brilhava à luz do sol (...) Marylin Monroe era a mulher que eu desejava profundamente para mim e que todos desejavam e ela me pertencia." $P A-$ p. 59. 
capitalista. Aliás, não seria exagero uma leitura de Panamérica como um parente distante, mas assim mesmo descendente direto, do poema épico O Guesa Errante.

Agrippino conseguiu também numa única tacada, nesta cena final, reunir duas das imagens favoritas de Brecht: a primeira delas, essas figuras pantacruélicas de puro afeto, incapazes de frear seus desejos básicos, comendo até que estourem suas tripas (lembremos a cena do banquete em Baal); a segunda, a escolha de Wall Street e da Bolsa de Valores como cenário para um Match de alta expressão cênica (Brecht adorava comparar o espetáculo teatral as lutas de boxe lembremos o adendo, a cena complementar de Um Homem é um Homem em que o narrador desafia um homem da platéia para que o desfecho da peça seja decidido numa luta entre eles sobre o ringue; e tinha fascínio, evidentemente, por Wall Street, vide Santa Joana dos Matadouros). Para completar, deu uma dimensão ainda mais escatológica a cena ao estabelecer na regra do jogo: todo alimento digerido deveria sair pelo cu. ${ }^{147} \mathrm{Um}$ novo mundo homérico de deuses e monstros (do capital) se desenha a partir do grotesco e dos traços homorísticos da cultura popular: ao choque de (n)ações (a guerra na era do capitalismo financeiro) sobrepõe-se o choque das esferas (alta e baixa) da cultura.

Aquilo que o distingue de Brecht é que esse imaginário em confronto não alimenta um teatro dialético, onde a contradição entre as diferentes esferas surge como método ${ }^{148}$, mas sim uma dramaturgia das multiplicidades por elas mesmas. Devorando 1259 bois, Carlo Ponti sai vitorioso quando Di Maggio, não resistindo a fortes contrações na barriga, vomita, provocando imediatamente sua desintegração cósmica em milhões de fragmentos. O que se segue é uma verdadeira hecatombe, com Hollywood sendo tragada para dentro de um buraco imenso aberto na terra - tudo transmitido por grandes telas de TV. O narrador, nanico, escondido entre 1263 homossexuais do gineceu de Di Maggio teme, por instantes, por sua vida, mas quando Carlo Ponti anuncia que todo o espólio do derrotado agora the pertence, este comemora como um escravo liberto. A cena, no entanto, não parece confirmar toda esta euforia, com Carlo Ponti sendo conduzido como

147 Desde de algumas poucas cenas já vislumbradas em Lugar Público, o épico grotesco e o descomunal tornaram-se de suma importância na poética de Agrippino - guardarei a oportunidade de esclarecer melhor alguns desses pontos durante as análises de Hitler $I I^{\circ}$ Mundo.

148 JAMESON. O Método Brecht (ver bibliografia) 
um novo déspota vitorioso sentado sobre um enorme falo negro, marchando triunfante às voltas de uma cavalaria de falos gigantes e sob uma artilharia aérea de genitálias femininas. Do império romano ao império americano e vice-versa: a genealogia imagética construída por Hollywood se perpetuará em Cinecittá. Não há forças de transformação social numa Epopéia, apenas a pura teodicéia (do Capital), agora encenada em toda a sua magnitude espetacular para as câmeras de TV. A libertação não está no jogo de cena, mas na escrita: uma linguagem-objeto, inumana, contra as palavras envelopadas pela tradição.

Terminado seu périplo por esta Panamérica, exterminadas as forças do seu “algoz” fálico Di Maggio, arrefecido o desejo da carne que o ligava a máquina mitológica Marylin Monroe, só resta a nosso "herói" um último momento de autoconsciência. No Canto IXX, ele perambula por uma cidade coberta de borboletas, onde após um breve blecaute de energia (a ameaça permanente de um retorno às trevas), tudo volta a funcionar em paz. É neste momento que a narrativa alcança o máximo de sua auto-referencialidade:

\footnotetext{
"Eu engoli o último pedaço de bolo e depois eu vi que eu segurava um livro e alguns papéis que eu tinha escrito. A água da chuva poderia borrar as minhas letras e eu resolvi guardar o livro e os papéis no bolso da frente da capa. Era um bolso grande e eu introduzi o livro e os papéis e fechei o zíper. Mais uma vez eu me senti feliz de poder proteger o que eu tinha escrito." (PA, p - 235)
}

Diante deste último estabelecimento da ordem, a volta do blecaute, o narrador percorrerá uma derradeira aventura: ele encontra na rua uma menina de dez anos, que o leva para sua casa - onde a tia da menina, desconfiada, prepara um jantar em família - para lhe prestar favores sexuais em troca de algumas moedas. Esta promessa de satisfação sexual pré-púbere guarda um tom de complexo, de retorno ao sujeito fetichizado. Assim como esses papéis escritos do trecho acima citado se salvam do dilúvio (o sujeito da escrita se salva), assim o sujeito introspectivo, edipiano, ameaça se reintroduzir na narrativa. Pois é justamente para salvar o pensamento desta "defecação" - a palavra verbalizada, o humanismo revisitado - que o livro deve suspender-se. No canto seguinte, o $\mathrm{XX}$, dá-se o Apocalipse: padres tocando violinos inserem os corpos de mil cegos em tonéis de 
gasolina; a Estátua da Liberdade desperta enfurecida, esmagando com os pés todo aquele que cruzar seu caminho; dois gigantes formados com os corpos de milhões de homens destroem os edifícios da cidade; uma chuva de frangos assados toma de assalto os céus; um peixe cósmico sem tamanho devora a paisagem, mantendo milhares sobrevivendo no seu ventre, até que atacado por bactérias, dissolve-se no ar, encalhando sua carcaça na pista de um aeroporto; exércitos de robôs chocam-se contra aviões kamikases, restando a Dom Quixote combatê-los com lança em punho; o presidente Lyndon Johnson, cuja cabeça alcança as nuvens, tenta acalmar a população com discursos de fé enquanto os violinos não cessam de tocar, até que enfim a terra começa a se inclinar dobrando-se na direção da outra metade de si mesma - como num big bang às avessas, esse Apocalypse parece se dar num retorno ao átomo primordial, ao todo infinitamente pequeno e concentrado. Só que ao interromper subitamente a narrativa, num período em que o narrador tem um vislumbre do fim dos tempos vendo-o refletido nos vidros dos edifícios que avançam em sua direção, é a escrita, essa colheita de impurezas, quem garante que esse retorno ao inanimado seja, na verdade, uma nova repetição que recomeça, uma volta ao impensado, uma outra ordem nascente a partir do caos. A literatura, como o próprio modo do impossível, só pode dizer o seu vazio, mas ao dizê-lo funda uma nova plenitude, uma plenitude destotalizada, de onde brota esta epopéia contemporânea. 
Hitler III ${ }^{\circ}$ Mundo (1968) 
Era o ano luz de 1968. A secretaria de cultura do Estado de São Paulo havia acabado de constituir sua "comissão de dança" e para azeitar a máquina decidiu promover, em parceria com o SESC, o $1^{\circ}$ Festival de Dança de São Paulo. Coube a Miroel Silveira, diretor do Sesc e figura respeitada no cenário teatral paulistano (hoje seu nome batiza uma das duas salas do Teatro Laboratório da EAD-USP), a responsabilidade última de organizar o evento. Sem titubear, ele convidou logo Maria Esther Stockler para integrar a seleção. Desde de que voltara dos Estados Unidos - onde fora realizar um curso de pós-graduação em psicologia e onde acabou por optar de vez pela dança moderna após frequentar aulas com Martha Graham - Maria Esther vinha sendo requisitada na cidade para trabalhos esporádicos entre grupos de teatro. Foi dela, por exemplo, a preparação coreográfica de espetáculos do OFICINA como o famoso O Rei da Vela (1967) e o mais desconhecido Poder Negro (1968) - um texto de Le Roi Jones dirigido por Fernando Peixoto. Maria Esther aceitou imediatamente o convite de Miroel enxergando nele uma oportunidade única de criar seu próprio grupo, já que o Festival oferecia aos participantes uma boa quantia em dinheiro para a montagem dos espetáculos.

Tratou-se então de fechar o "núcleo duro" do tal grupo, que seria constituído, além de Maria Esther, por José Agrippino de Paula, já então seu companheiro afetivo, por um amigo próximo, Carlos Eugênio de Moura, e pela bailarina Yolanda Amadei, parceira de Maria Esther desde os tempos em que as duas eram jovens aprendizes sob a batuta de Maria Duschenes - uma dançarina húngara radicada no Brasil que havia estudado nos anos anteriores a Guerra na prestigiosa escola inglesa Dartington Hall onde tivera como professor Rudolf Laban ${ }^{149}$, tornando-se depois sua discípula

149 Laban, dançarino e pedagogo húngaro, desenvolveu um famoso "método" de notação dos movimentos na dança, ainda hoje bastante popular entre os estudantes de artes cênicas. Suas análises das leis físicas dos movimentos resultaram na "dança coral", uma prática artístico-pedagógica em que um dançarino (individuo) explora sua presença 
com visitas frequentes ao Laban Center of Movement em Londres. Não custa esclarecer que o projeto maior da Dartington Hall era justamente desenvolver pesquisas em que modernas técnicas de dança se conjugassem a outras formas de expressão como o teatro e a música, sendo um dos embriões dessa percepção tão contemporânea da utilização do corpo do ator como forma, algo que até então pertencia a dança, mas que vai se estender aos poucos para o teatro. Com Yolanda, Maria Esther havia fundado também em São Paulo o grupo experimental de dança Móbile que ensaiava no estúdio de José Roberto Aguilar na rua Frei Caneca, então ponto de encontro da vanguarda paulistana. Foi lá que ela conheceu José Agrippino de Paula.

Os experimentos do Móbile, no entanto, segundo a própria Maria Esther eram “muito eruditos, nada populares, de difícil comunicação com o público (...) principalmente Stockhausen..." ${ }^{150}$ Ela, por outro lado, intentava um espetáculo que pudesse, digamos, ficar mais tempo em cartaz atingindo assim um maior número de pessoas - ou seja, era preciso montar algo mais próximo do teatro. Decidiu-se então que o novo grupo trabalharia em cima de um conceito popularizado à época pelo Living Theatre, que Maria Esther havia visto em Nova York, e que consistia basicamente no que se convencionou chamar de mixed midia - uma mistura dos meios. Assim nasceu o SONDA, batizado desse modo provavelmente como uma referência pop aquela nova era espacial de foguetes e homens do espaço, atentando, obviamente, para o caráter inovador e experimental dessas aventuras. A sonda é aquilo mesmo que se lança ao desconhecido em busca de outros mundos e horizontes - enfim, em busca de uma nova linguagem.

A primeira montagem do SONDA, apresentada no Teatro Anchieta do Sesc Consolação dentro do $1^{\circ}$ Festival de Dança de São Paulo em 1968, intitulou-se Tarzan $I I I^{\circ}$ Mundo - $O$ Mustang Hibernado. ${ }^{151}$ A criação coreográfica era toda de Maria Esther a partir de experimentos coletivos desenvolvidos em conjunto com os atores (boa parte deles amadores selecionados em testes). Por outro lado, a criação dramatúrgica das cenas, cenários e figurinos, para reforçar a proposta no espaço cênico (e na vida) sempre em relação a dinâmica do coro (do grupo).

150 In: MADAZZIO. O Vôo da Borboleta - p. 36.

151 Uma descrição completa das cenas do espetáculo pode ser encontrada na dissertação de mestrado de Irlainy Madazzio (acima citada) sobre as montagens do Sonda. 
de mistura de meios, foi dividida entre diferentes artistas, independentes nas suas concepções: Efízio Putzolu, artista plástico com participação frequente nas Bienais de São Paulo da década de 60, concebeu duas cenas (e seus respectivos cenários e figurinos), sendo a primeira delas $O$ Homem Hibernado, baseada na "instalação" Hibernazione $n^{\circ} 5$ recentemente apresentada por ele mesmo no XV Salão de Arte Moderna (cena que inspirou o título do espetáculo e que por sua vez se inspirava nos filmes e séries de ficção científica do período em que homens congelados e hibernados despertavam séculos no futuro); outra cena, concebida por Jô Soares e intitulada Dupla Dinâmica, colocava em cena os heróis dos quadrinhos Batman e Robin tomando uma baita surra dos bandidos que tentavam capturar (sem falar nas flagrantes insinuações de homossexualismo entre os dois); a artista Sarah Ferres concebeu uma outra cena denominada Luta onde um match de boxe se transformava em coreografia livre ao som de ragas hindus e passos de dança inspirados no candomblé.

Para completar, duas outras cenas foram criadas por Agrippino: o epílogo, intitulado Paz Mundial, onde um casal de negros interpretava Adão e Eva ${ }^{152}$ numa borracharia ao som da 'Missa para Órgão' de Messiaen; e uma outra cena intitulada genericamente Tarzan III ${ }^{o}$ Mundo, onde uma série de peripécias se desdobram num cenário (sobras de um carro destrinchado em meio a materiais plásticos, tudo permeado por imagens de televisão) que evocava a estética do lixo (a marca do $3^{\circ}$ Mundo) justapondo-a a um apurado trabalho coreográfico e técnico (é preciso lembrar que o Teatro Anchieta era à época um dos teatros mais bem equipados da cidade, com facilidades únicas para a montagem dos cenários, além de equipamentos de áudio, vídeo e iluminação praticamente não encontrados nas demais salas de espetáculos). Essa combinação de uma novidade de linguagem $\left(\right.$ dança + teatro + cultura de massas), com apelo temático político (o caos do $3^{\circ}$ mundo) e com certo apuro técnico (efeitos de luz, som, figurino e cenário raramente antes vistos) transformou Tarzan III $^{\circ}$ Mundo, apesar de seu amadorismo (pelo menos eu imagino) e de um certo atabalhoamento na

152 Esse casal adâmico (re)aparece em Hitler III ${ }^{\circ}$ Mundo numa breve cena (happening) de apenas dois planos, absolutamente solta dentro da "narrativa" do filme: nela, vemos o casal se livrando, nus, de um invólucro (placentário) de alumínio, (re)nascendo assim de uma longa hibernação num parto cósmico (de espaço-tempo). 
execução (segundo relatos), num acontecimento de importantes consequências para o rumo das artes cênicas no país.

Hitler III ${ }^{\circ}$ Mundo é fruto direto deste espetáculo de estréia do SONDA (e o título não me deixa mentir). Não apenas porque foi o relativo sucesso deste primeiro empreendimento cênico do grupo que alimentou as forças para a realização do filme, mas sobretudo porque boa parte da proposta estética que encontramos explicitada na tela nasceu em grande medida com a realização de $O$ Mustang Hibernado. De fato, o filme dirigido por Agrippino me parece uma transcriação, uma potencialização das experiências realizadas pelo SONDA no palco do teatro Anchieta. Estamos diante, portanto, de um caso único em nossa filmografia até então: um filme realizado como parte integrante das pesquisas cênicas de uma trupe teatral de vanguarda ${ }^{153}$. É evidente que Hitler III $^{\circ}$ Mundo é também muito mais que isso: ele é o sonho maior de uma arte-soma, se considerarmos que o cinema é igualmente o sonho ulterior da soma de todas as artes (não nos esqueçamos do significado da denominação sétima arte: aquela que contém em si todas as outras).

Filmado com sobras de negativos, de figurinos e de idéias, com equipe técnica mínima geralmente reunida as pressas e atores convidados atuando de forma improvisada, Hitler $I I I^{o}$ Mundo é, no seu modo de produção, um exemplar dileto do movimento udigrudi que varreu nosso cinema na virada dos anos 60 para a década de 70 - disso não há dúvidas. Quanto a sua relação mais profunda com alguns dos nomes mais prezados do Cinema Marginal caberá a este texto algumas ponderações pontuais (assim como algumas palavras me cabem sobre as relações de Agrippino com a ebulição do movimento tropicalista). Antes de tudo, vale lembrar que Hitler III $^{\circ}$ Mundo jamais alcançou as telas de cinema em uma exibição comercial (e como poderia?), cumprindo desde seu nascimento uma vocação para o subterrâneo.

153 As relações entre as grandes experiências teatrais do país (o TBC, o Arena, o Oficina) e sua influência (diálogo) mais especifica sobre a produção cinematográfica de cada época é um trabalho que ainda está para ser escrito. Minha impressão é que, no caso do SONDA, trata-se da primeira vez que um grupo teatral assume a realização de um filme como parte integrante do seu repertório de pesquisa e ação. Podemos, talvez, lembrar o caso do primeiro filme de Glauber, Pátio, filmado no ambiente universitário de experimentação próprio da Escola de Teatro da Universidade da Bahia (então talvez a instituição brasileira mais afinada com as vanguardas internacionais). Assim, o "cinema não é para eles apenas uma forma teatral complementar, mas a possibilidade de realizar a mise-en-scene contemporânea tal como a querem e sentem". (BAZIN. Teatro e Cinema. In: O Cinema: Ensaios - p. 163). O Sonda dará um passo adiante nessas propostas ao transfigurar teatralmente o cinema numa arte-soma. 
A primeira imagem de Hitler III ${ }^{o}$ Mundo invoca um caldeirão borbulhante. A câmera está bem acima dele, vemos toda a circunferência de sua boca, estamos prestes a imergir na fervura. É claro que, no fundo, suspeitamos tratar-se apenas de um tímido recipiente doméstico transfigurado pelo "poder" da objetiva. A banalidade do objeto, no entanto, é parte do efeito: o cinema é bruxaria, todo mundo sabe. Estamos então diante deste "caldo primordial" - ao fundo, ouvimos um som crescente, como o de uma turbina de avião em plena decolagem. Tudo o que vier depois dessa imagem será o jorro, a palavra desunida (dia-bolo), lançada (spelling / feitiço), que aspirará sempre ao retorno.

Aliás, antes mesmo desta imagem-invocação, que nos remete ao prólogo das bruxas em Macbeth, temos uma debochada sequência de abertura onde uma música acentuadamente rítmica (batuques) acompanha a máquina de escrever que datilografa os créditos. Música esta que, por sua vez, aparece permeada por ruídos (grunhidos) animalescos. Tal sutil (de)composição não deve passar por nós simplesmente desapercebida. Ao acreditar na montagem independente de planos presente em toda a obra de Agrippino (dos parágrafos soltos de LP à justaposição de cenas em Tarzan), esta mera apresentação textual do filme já traz em si um espanto primeiro. Despersonalizada, a máquina de escrever não aparece ali como uma referência a uma escrita mais pessoal, mais autoral, pelo contrário, com cortes bruscos e uma leve aceleração na velocidade da imagem, o que temos neste preâmbulo é uma aproximação serial dessas duas máquinas de signos: o cinema e a escrita mecânica. Se PA começa com um circo cinematográfico, o cinema de Hitler começa com uma máquina de criar palavras (verbos).

Ora, é Mcluhan quem nos lembra do mito grego de $\mathrm{Cadmo}^{154}$, o rei que teria

154 MCLUHAN. Os Meios de Comunicação como Extensões do Homem - p. 105-107. 
introduzido as letras do alfabeto na Grécia e que também, ao semear os dentes do dragão, germinou uma legião de homens armados. O alfabeto fonético torna os homens livres ao preço de arrancar-lhes os sentimentos familiares, grupais e sentimentais de suas tradicionais vidas em comunidade, sendo a mais radical tecnologia de homogeneização da cultura. A máquina de escrever, a escrita mecanicamente seriada, não deixa de ser uma das maiores realizações desse processo de homogeneização. Nesse universo benjaminiano da 'reprodutibilidade técnica', a fortuna cabalística da criação do mundo pela manipulação das letras se dá através do inumano divinizado: o Sr. Olivetti e suas séries intermináveis de máquinas. ${ }^{155}$ Se o diagnóstico de Mcluhan aponta o homem letrado como um homem doente, a crítica anti-humanista da década de 60 vai mais longe ao vaticinar que a automatização lingüística das máquinas de escrever partilha o ser das imensas máquinas de queimar gente, ser igualmente partilhado pelo dispositivo cinematográfico.

Na seqüência de abertura de Hitler $I I^{o}$ Mundo temos então um primeiro rito de expiação dessa racionalidade instrumental: a "máquina de escrever" desponta como o objeto do poeta, aquele que pode purgar a língua ao fundar dentro dela uma 'outra língua', e nesse sentido, também como o próprio cinema, como um filme de poesia. Mas essa escrita (sujeito) só pode nascer instaurando o ritmo e o ruído no mundo. O ritmo é, por excelência, a dimensão musical mais próxima do corpo (a marcação de ciclos); o ruído, por outro lado, é a forma do acaso e da desordem. Em nossa longa marcha rumo a civilização, os ritmos (o corpo) foram controlados e os ruídos (o caos) suprimidos. Não é à toa, portanto, que a "música das esferas”, o sistema tonal melódico-harmônico, busca subjugar a estrutura rítmica ao mesmo tempo em que elimina das partituras toda a cacofonia. ${ }^{156}$ Há um preço a ser pago na constituição do sujeito civilizado. Pois em Hitler, os grunhidos violentos

155 O mesmo acontece com a "edificação edipiana”. No romance Adam Filho de Cão publicado em 1966 pelo escritor israelense Yohan Kaniuk e que tem como personagem principal justamente um homem que sobreviveu ao Holocausto ao assumir a personalidade de um cão, narra-se lá pelas tantas a história de como num hospital psiquiátrico no meio do deserto, o processo contrário aconteceu e um cão virou um menino de tanto bater a máquina. O menino, agora apoiado em duas pernas, escreve emocionado uma carta ao seu herói: "Sr. Olivetti, será que o senhor sabe que um cão no Instituto de Terapia de Arad tocou em você o réquiem satânico? Sr. Olivetti, será que o senhor sabe que, em seu piano, um cão, gravou com buril sobre-humano, uma carta de amor? Sr. Olivetti, eu o saúdo de longe, de Arad, de fora, do deserto." in: KANIUK - p. 226.

156 Uma reflexão histórico-crítica sobre essas questões pode ser encontrada no livro O Som e o Sentido: uma outra história das músicas de José Miguel Wisnik (ver bibliografia). 
que sobrepõe-se as batidas da máquina devem "dar a luz" não ao sujeito feliz do conhecimento, mas ao olhar imenso das coisas (logo em seguida surgirá a fervura do "caldeirão") - o cinema como diabolo, não como sim-bolo.

É esse rito de iniciação que nos encaminha até o local que realmente interessa ao filme: o seio da nova classe média urbana brasileira. Temos assim esse casal metropolitano numa pequena aventura certamente inspirada na cena da borracharia - o epílogo de Tarzan $I^{\circ}{ }^{o}$ Mundo $^{157}$. Essa aventura nos será apresentada em três partes: a primeira se passa numa cozinha; num plano inicial, vemos bem no canto direito do quadro a ponta do que parece ser uma geladeira. Uma mulher entra nesse mesmo quadro pela esquerda e abre esta geladeira, ela tem um lenço na cabeça (marca da sua classe). $\mathrm{O}$ enquadramento é estranho, impreciso, vemos a mulher apenas dos ombros para cima. Ela então se volta, ameaçando dizer alguma coisa. Subitamente o homem irrompe na tela. Olhando para a câmera, ele gesticula e fala sem parar. Entendemos então que toda a "escrita" do quadro estava a sua espera, daí a sensação de estranheza, pois quando ele aparece este finalmente alcança o equilíbrio interno: o homem perfeitamente enquadrado, frontalmente, em plano médio. O quadro se oferece ao homem, é seu cúmplice. Não à toa, quando ele entra em cena oculta totalmente atrás de si a mulher. É a imagem da família brasileira: o bem de consumo, a mulher e, por fim, o homem, o varão valoroso da pátria. Só que se o quadro por um lado parece cúmplice do homem (ele nos remete aqueles enquadramentos televisivos da época, preparados para os pronunciamentos de políticos como Carlos Lacerda ou de apresentadores como Flávio Cavalcanti - ou seja, um palanque para moralismos) outros elementos vão "sabotar" este arranjo: em nenhum momento ouvimos a sua voz, apenas o som da turbina cobrindo todo o plano; a própria interpretação do ator que representa o homem é ridiculamente estilizada, sua boca parece descomunal, seus gestos são risíveis. Assim, a “cumplicidade" aparente do quadro se revela, na verdade, uma primeira impostura, o lugar mesmo do patético. De certo modo esse é o esquema geral para o filme de Agrippino: a construção de planos

157 Assim como PA começava onde LP havia terminado (no cinema). um novo começo acontece aqui a partir do final anterior, uma nova desordem florescendo da obra anteriormente "acabada", o que nos dá a exata noção de como a poética de Agrippino se desdobra como um projeto onde se destaca uma repetição criadora. 
"bem feitos", que evocam certo rigor geométrico, contrapõe-se a cacofonia de ruídos e solilóquios na banda sonora e a materialidade muitas vezes grotesca dos gestos e dos corpos.

Percebemos bem isso no segundo plano da cozinha, um contra-picado espalhafatoso que revela o nosso homem de classe média postado num terno preto, com a gravata alinhada, esfregando histrionicamente as duas orelhas. Esse gesto boçal do homem funciona como uma espécie de rubrica da cena - sabemos imediatamente que estamos diante de um tipo mais que de uma personagem. Assim, no plano seguinte saímos da cozinha e alcançamos a segunda parte de nossa "aventura". No coração da cidade, vemos o mesmo casal dentro de um fusca empacado no meio do rua. A cena é cômica, chanchadesca, o carro chacoalha, ameaça sair do lugar, mas nada. O plano é aberto, destacando o movimento dos outros carros e das pessoas. A construção do quadro também, aparentemente, foi pensada para destacar o movimento: a sobra de espaço à direita do quadro, em frente ao fusca (além do fato de que sua traseira é cortada pela borda esquerda, não aparecendo na tela) indica o sentido do movimento que, aliás, é o sentido mais tradicional. Sabemos disso depois de mais de cinco séculos de iconografia fundamentada por coordenadas matemáticas, ou melhor, de “representação figurada baseada nas relações métricas e no valor relativo dos objetos", ${ }^{158}$ nosso conjunto de regras visuais. No cinema clássico, o 'plano do fusca' poderia muito bem ser um 'plano de continuidade'. Seria "natural" imaginarmos isso: o casal estava na cozinha, o homem havia entrado em cena da esquerda para direita, se eles fossem sair de carro, o mais óbvio seria um "plano de continuidade" que mostrasse o carro percorrendo uma rua da esquerda para direita (eis a linguagem cinematográfica). A montagem (clássica) sempre deve privilegiar a fluidez da narrativa: a continuidade espacial e temporal confirma nossas expectativas de conclusão e significado. ${ }^{159}$ Lá estamos nós então, diante do fusca. Ele faz que vai (nós vamos com ele), mas não vai. O quadro, todo “confeccionado" para o movimento do carro, é uma "impostura" do cineasta: ele quer transmitir a

158 FRANCASTEL, P. Espaço Genético e Espaço Plástico in: A Realidade Figurativa - p. 150. Francastel considera essa representação figurada dos objetos, que os vê "não mais como duplos da idéia, mas como signos dialéticos aos valores modificáveis", o grande achado da Renascença que nem os modernos rejeitaram.

159 BORDWELL, D. \& STAIGER, J. \& THOMPSOM, K. The Classical Hollywood Cinema: film style and mode of production to 1960. - Cap. 1. 
“idéia" do movimento ao mesmo tempo em que o aborta continuamente. O único movimento quem faz é a montagem: um jump-cut ressalta o 'ato do plano' que se desdobra em outro para continuar o mesmo, chamando atenção apenas para si mesmo.

Na banda sonora, por sua vez, os ruídos da turbina do avião que até então recobriam todas as cenas dão lugar a uma impagável voz over que num monólogo aparvalhado discorre sobre a falta de solidariedade das grandes metrópoles: "Furou o pneu! Quem vai nos socorrer?" Os carros na rua passam apressados, ninguém parece se importar muito com o casal afora o fato deles estarem atravancando o caminho - daí os lamentos hiperbólicos do narrador: "morreremos nesse automóvel fechado... entraremos em estado de decomposição", e não virá ajuda. A cena, acentuada pela narração chanchadesca, é engraçadíssima, mas a todo instante a morte está à espreita um tema bastante afeito a "sensibilidade" dos cineastas marginais. Ismail Xavier, analisando o filme Bang Bang de Tonnacci, ${ }^{160}$ destaca o buick errante (o automóvel) como o único telos do filme, sacrificado pela explosão: a promessa de consumo associa-se à imagem da morte. No filme de Agrippino, essa promessa de consumo impregna-se de uma impossibilidade essencial igualmente teratológica: às vésperas do milagre econômico, na crista da onda de uma revigorada indústria automotiva nacional (cujo símbolo era justamente o fusca), no coração da nova metrópole extática da sociedade da mercadoria, o carro simplesmente não "anda" - a modernização conservadora é o "pneu recauchutado" do progresso (e da ordem).

Chegamos então a terceira parte de nossa aventura com o casal. Num plano picado tomado do alto, do teto (novamente bastante estilizado), vemos o casal chegando na borracharia com um pneu. Outro corte e estamos agora no pátio, próximo ao casal. O homem exige de um funcionário, com um gesto boçal (e autoritário), o conserto imediato do pneu. Corte: plano do pneu no chão. Aqui se dá então outra impostura: quando pensamos que o funcionário levará o pneu para a recauchutagem, surpresa, é o homem que se agacha em quatro apoios deixando que o empregado da borracharia o leve para manutenção! Percebemos então que a morte à espreita não traz 
consigo qualquer sentido trágico de expiação - o que temos aqui é a mais completa reificação: a repetição (a recauchutagem) adquire aqui uma feição mórbida, a morte em série (a técnica).

Por fim, a cena-apoteose: o homem, levantado por uma grande suspensão hidráulica, sobe as alturas (da borracharia) com a eloqüência estúpida de seus gestos espraiando-se num amplo plano geral. É o triunfo da vontade da classe média. O desdobramento último desta cena está numa sequência sinistra que se coloca já além da aventura do casal (constituindo, na verdade, seu fecho). São três breves planos: no primeiro, vemos o rosto do homem contra o céu, depois, num segundo plano, vemos corpos espalhados pelo chão e o mesmo homem escolhendo um dos corpos e o arrastando por um corredor, finalmente, um terceiro plano, muito similar ao primeiro, fecha a moldura. Não é preciso dizer muito mais: o nosso bom homem de classe média está metido em tramas sub-repitícias que nos remetem a repressão e a tortura.

Esse tríptico final só vem reforçar uma suspeita espalhada pela banda sonora desde o começo da sequencia na borracharia: nela, uma narração (over) sussura frases desconexas do tipo “é preciso ficar de olho no progresso dos gritos, senão o elemento morre". A referência à tortura é evidente. Essa fala, por sua vez, parecer ser da figura que está em cena, nosso caro homem da classe média, mas a forma ruídosa e desconectada como ela se apresenta (em over) impõe-nos uma impessoalidade da fala que acaba por espalhar-se por toda a seqüência de imagens (rompendo com a relação intersubjetiva, fundamento do drama), chegando mesmo até o espectador na medida em que problematiza a identificação. É um recurso formal semelhante ao da repetição maçante do pronome EU em PA. Ele deixa-nos sempre com a pergunta: quem será essa pessoa que nos fala? Ou ainda: não será pois este Hitler $3^{\circ}$ Mundo do título menos um personagem (Hitler encravado nos trópicos contando-nos suas memórias) e mais uma fala em lingua morta? Vejamos.

Em Hitler, mesmo nos poucos casos em que o diálogo das personagens é audível e compreensível ao espectador, um (d)efeito de mixagem provoca um ruído na construção do sentido: os diálogos aparecem em cena fora de sincronia, segundos depois da ação. Jorge Bodansky, 
num depoimento a TV Sesc ${ }^{161}$, relatou o fato de que durante a mixagem de som do filme uma primeira cópia foi realizada com a banda sonora atrasada em relação ao corte das imagens. Agrippino gostou tanto do descompasso que incorporou a "falha" a montagem final. É o ideal da arte-soma: uma obra de ações e acidentes, de escolhas e acasos; uma obra de esferas autônomas que se interpenetram e/ou se repelem, assim, a banda sonora entra no filme como "soma" e não como parte do produto.

\begin{abstract}
"Um diálogo de filme, qualquer coisa que ele diga, nunca é completamente diegético (...) o elemento verbal custa a se integrar totalmente no filme. Ele transborda forçosamente. A palavra é sempre um pouco porta-voz. Ela nunca está dentro do filme, está sempre um pouco na frente". ${ }^{162}$
\end{abstract}

Agrippino leva ao paroxismo a constatação semiológica de Metz justamente porque lhe parece tentador trabalhar no limite das significações, especialmente naquele momento histórico do país. Se em LP, três anos antes, ele ainda demonstrava uma certa euforia técnica e poética pelos sentidos da modernização (um espiar com deleite os grandes monumentos da urbanidade e das vanguardas contra a tradição engessada das virtudes históricas), em Hitler, realizado as vésperas do AI-5, acentua-se um certo desolamento. É o choque entre a modernidade possível (que incluia uma transformação das bases sociais) do Brasil pré-golpe (e que não cessou de toda após 1964) e o fantasma já então patente do recrudescimento da ditadura, dos auspícios da modernização conservadora e do milagre econômico. A euforia com as reformas e a marcha ao progresso dava lugar a um exame profundo de consciência. Foi Jean Claude Bernardet, em seu célebre livro de $1967^{163}$, quem primeiro chamou a atenção para a necessidade do cinema novo brasileiro ser capaz de lidar com as estruturas de sua própria classe, afinal, ele nada tinha de popular, mas era o cinema de uma classe média que procurava o seu lugar na história. A própria dedicatória do livro, endereçada a Antônio das Mortes, era provocativa. Para Bernardet, a dimensão trágica do 'matador de cangaceiros' inaugura uma nova fase em nosso cinema: a reflexão sobre as contradições da pequena burguesia.

Lembro também o seu diagnóstico/prognóstico a respeito dos filmes feitos no

161 A Tv Sesc exibiu, em 2007, alguns programas especiais em virtude do falecimento de Agrippino, incluindo uma exibição de Hitler $I I^{\circ}$ Mundo. Como introdução ao filme, o canal mostrou entrevistas com alguns envolvidos na produção como os cineastas Jorge Bodansky (que fez a câmera e a fotografia do filme) e Hermano Penna.

162 METZ, C. A Significação no Cinema. p. - 70/71.

163 BERNARDET, J.C. Brasil em Tempo de Cinema. (ver bibliografia) 
período. Nele, um cinema sobre a classe média já se esboçava (em O Desafio, em São Paulo S/A), mas nunca indo além de um "impasse angustiado" francamente castrador. Contra essa tendência havia apenas uma névoa: o surgimento de um "realismo poético revolucionário" que se anunciava em Terra em Transe (ainda no roteiro) e realizava-se de forma um tanto primitiva em À Meia-Noite Levarei sua Alma. Bernardet se preocupava por enxergar nesse "desespero apático" dos filmes brasileiros do pósgolpe o prenúncio de um cinema fascista. Ele tinha um alvo imediato na cabeça quando se referia a esse tipo de cinema: toda uma onda crescente de documentários curtos, com fortes tons de musealização histórica, que se aproveitando dos protecionistas esquemas de distribuição passaram a inundar as telas do país.

É esse "fascismo da classe média" que interessa ao cinema-soma de Agrippino, ele chega mesmo a evocar no classicismo hiperbólico de seus enquadramentos essa musealização, só que a subverte continuamente num jogo de somas e subtrações. Para tanto, nota-se que a tortura interessa ao filme não apenas como discurso, mas também como aquele acontecimento figural ${ }^{164}$ irredutível a linguagem. Se a morte e a tortura estão à espreita, e se o dispositivo técnico do cinema e das representações parece compactuar com essa lógica coercitiva, o único jeito é fazer explodir (como já sugeria o anão-profeta de $O$ Bandido da Luz Vermelha) as estruturas e os signos que enclausuram o pensamento.

Voltemos então a essa justaposição direta HITLER III ${ }^{\circ}$ MUNDO, sem aditivos ou conjunções. Essa construção paratática trata menos frontalmente da persistência do fascismo nas entranhas obscuras do mundo pobre, através da discussão muito popular à época de que os nazistas estariam refugiados na América do $\mathrm{Sul}^{165}$, e mais, por meio de uma “contaminação" semântica, da

164 LYOTARD. Discurso, figura. A tese central de Lyotard é que a cultura ocidental supre sempre o figural (aquilo que expressa mais uma força que um significado, que tem mais existência que função) em detrimento do discursivo (aquilo que é logicamente ordenado e dotado de sentido). A separação remete a Freud e sua distinção entre dois tipos de princípios: os princípios primários (aqueles próximos do prazer, como está o figural) e os princípios secundários (o princípio de realidade, aquele responsável por disciplinar as pulsões, associados aqui ao discursivo).

165 Lembremos a referência implícita (e explícita) em O Bandido da Luz Vermelha de que o crime organizado e a classe política brasileira tinham ligações com grupos terroristas (fascistas) internacionais - há inclusive aparições de uma figura que remete a Martin Boorman, o (ex)carrasco nazista que, segundo a narração jocosa, estaria negociando dólares falsos no Guarujá (a "realidade" provou-se ainda mais ridícula com o doutor da morte Josef Menguele, depois de uma escapada inacreditável das mãos dos aliados na Europa, vindo morrer, anos depois, durante um brejeiro "banho de mar" em Bertioga!). É preciso destacar ainda sobre o tema o filme de Silvio Back Aleluia 
presença de aspirações fascistas nas malhas ideológicas da democracia subdesenvolvida e da sociedade de massas. É preciso lembrar que a Revolução (a gloriosa) foi feita em nome da democracia com amplo apoio das camadas médias da população. Não se trata portanto de um Hitler do III $^{\circ}$ Mundo (o retorno do recalcado), nem de um Hitler no III $^{\circ}$ Mundo (que mais parece coisa do cinema americano, lembremos o filme The Boys from Brazil), mas sim de Hitler III ${ }^{\circ}$ Mundo - o entremundos, o pesadelo do porvir. A preferência, aliás, por misturar o algarismo romano III com a notação ordinal configura um afastamento em relação a seu sentido geopolítico usual ( $3^{\circ}$ Mundo).

É bem conhecido o fato de que a teoria dos mundos proposta pelo demógrafo francês Alfred Sauvy logo no pós-guerra se inspirou no famoso panfleto de Sieyès sobre o Terceiro Estado às vesperas da Revolução Francesa: O que é o terceiro estado? Nada. O que ele pretende ser? Tudo. E nesse sentido de união programática dos povos explorados que o termo é adotado oficialmente por um grupo de países africanos e asiáticos na Conferência de Bandung (Indonésia) em 1955. Dez anos depois, coube a Glauber Rocha transformar o Terceiro Mundo numa questão estética de vanguarda. No seu manifesto de 1965 intitulado Estética da Fome, Glauber associa a arte nova (o cinema novo) a fome ("nossa maior originalidade"), declarando em seguida que a missão dessa arte seria parir uma poética de "ação e transformação" (a partir do ventre da fome) que integrasse econômica e industrialmente os países (livres) da América Latina (e, num horizonte maior, todos os países que sofreram com o colonialismo) contra o "opressor" estrangeiro. O faminto liberto do julgo colonial (e não necessariamente o proletariado) passa a ser algoz do homem capitalista.

O notável de Glauber é que ele inculca esse negativo exatamente na mais industrial das artes: o cinema. $\mathrm{O} 3^{\circ}$ Mundo surge então em seus textos e em seus filmes como o lugar da oposição histórica ao $1^{\circ}$ Mundo, seu outro indignado e violento, sua pulsão bárbara e inconsciente que clama por libertação. Cabe a este cinema (novo) excitar os temas da fome e não escondê-la em filmes sobre a miséria moral da burguesia; cabe a ele representar o movimento dialético de recuperação do seu próprio ser no conflito entre a bárbarie e a civilização; entre escravos e senhores;

Gretchen (1976) que traça uma "genealogia" da presença da ideologia nazista no sul do país (e de possíveis refugiados) além das relações entre esta (estes) e o integralismo e depois com os golpistas de 64. 
entre o $3^{\circ}$ Mundo e o $1^{\circ}$ Mundo - daí os títulos de suas obras nesse período evocarem o movimento das utopias, o transe das consciências, o pêndulo entre as oposições constitutivas (Deus e o Diabo; o Dragão da Maldade e o Santo Guerreiro), os fênomenos que atravessam o céu e a terra (Barravento). Daí também a forte dimensão alegorica destes filmes: a alegoria é sempre uma coisa que pode significar o seu oposto (toda afirmação de sentido sempre pressupõe que o texto é sobre outra coisa) o mecanismo da alegoria investe-se da expectativa de que a oposição (Identidade X Diferença) se transforme em contradição. A fome é o gestus (aquele artifício auto-referencial que ensina ao mostrar a natureza do movimento) dessa contradição histórica fundamental.

De alguma forma, os filmes marginais dão continuidade a essa estética glauberiana da fome, mas cada um devora (faminto) o pai de modo muito particular. No caso de Hitler, que é aquele que nos interessa, fica claro desde o título que a questão é descoser a alegoria (a relação de oposição de sentidos) para afirmar o paradoxo (dois sentidos ao mesmo tempo) - não se aspira de modo imediato a uma representação do movimento (histórico; inconsciente), mas dá-se obra como movimento múltiplo (como soma). Isso fica evidente quando analisamos a relação entre os elementos que compõe o filme: os enquadramentos, a banda sonora, a montagem, a aparição dos corpos - eles geram ruídos constantes entre si, nunca alcançando uma síntese, um produto capaz de encarnar formalmente as forças em ação no drama. Ele, no máximo, as mostra. É o caso da fome. Em Hitler, a questão não é excitar a fome ${ }^{166}$, mas suscitá-la. A galeria de famintos está lá, com seus rostos fulcrados, na favela por onde o samuraí gordo (interpretado por Jô Soares) passeia, mas ela só existe como imagem justaposta ao grotesco da figura do samurai, que por sua vez parece retirada das páginas de um gibi barato. Um rosto precisa perder sua humanidade para renascer como um corpo sem face, uma figura de puro afeto. É a aposta um tanto "perversa" (a moralidade do termo ficando por conta do leitor) em um cinema de inumanidades - daí as acusações mútuas de fascismo (ofensa

166 "o cinema novo narrou, descreveu, poetizou, discursou, analisou, excitou os temas da fome: personagens comendo terra, personagens comendo raízes, personagens roubando para comer, personagens matando para comer, personagens sujas, feias, descarnadas, morando em casas sujas, feias, escuras; foi esta galeria de famintos que identificou o cinema novo com o miserabilismo tão condenado pelo Governo, pela crítica a serviço dos interesses antinacionais, pelos produtores e pelo público - este último não suportando as imagens da própria miséria." (o grifo é meu) in: ROCHA. A Estética da Fome in: Revolução do Cinema Novo - p. 65. 
maior na época) seja por parte de Glauber ${ }^{167}$ ao udigrudi marginal, seja por parte "destes" contra o

Cinema Novo ${ }^{168}$. Numa suma rápida: o problema está em que nos filmes de Glauber o que se busca é uma imagem do povo e as contradições decorrentes dessa busca, enquanto o que Agrippino (e Sganzerla bastante influenciado por ele a partir de $A$ Mulher de $\operatorname{Todos}^{169}$ ) nos oferece é uma radicalização desta imagem (bestial) do homem bestializado (massificado).

Em grande medida, o Cinema Novo foi a própria expressão cinematográfica do modernismo brasileiro ${ }^{170}$, sendo portanto herdeiro desta aspiração nutrida desde o Romantismo de construir e inventar um país (de leitores) através da literatura (e, depois, do cinema). Uma cinematografia precisa desesperadamente de um povo (e vice-versa) - esse é um ponto chave nas reflexões de um pensador como Paulo Emílio Salles Gomes, de grande influência sobre os cinemanovistas. Seguindo a "tese" que este trabalho vem defendendo, Agrippino, afinado ao discurso pop internacional, descartou o povo como uma hipótese desnecessária para sua arte, que é uma arte sem história da arte e, portanto, sem um história das representações do povo. A linguagem desumanizada reverbera essa impessoalidade vívida que é o mundo das massas - se há uma força

167 "O Udigrudi é uma dissidência golpista e arrependida do Cinema Novo" (p. 366) ou "os fetos do aborto udigrudi eram ridículas monstruosidades vomitadas pelo go-zynho dos jovens burgueses atormentados" (p. 477) ou ainda "Zé (Celso) tenta, com Rogério Sganzerla, uma via Anti-Cinema Novo. Para Zé, para a Boca do Lixo, e para a ideologia dominante na Cinemateca Brasileira - o Cinema Novo é um poder fascista." (p. 470) in: ROCHA. Revolução do Cinema Novo.

168 "Eu sou contra o Cinema Novo porque eu acho que depois dele ter apresentado as melhores ambições e o que ele tinha de melhor de 62 a 65, atualmente ele é um movimento de elite, um movimento paternalizador, conservador, de direita (...) estou querendo me ligar as expressões mais autênticas e mais profundas de uma vanguarda e eu acho que o Cinema Novo é exatamente anti-vanguarda," Entrevista de Rogério Sganzerla (e Helena Ignez) ao jornal $O$ Pasquim ( $\mathrm{n}^{\mathrm{o}}$ 33, 5-11 de Fevereiro de 1970) in: CANUTO (org.) Rogério Sganzerla (encontros) - $\mathrm{p}$.

169 É evidente que as montagens do Sonda influenciaram o cinema de Sganzerla. Em A Mulher de Todos aparecem elementos de cena extraídos diretamente de Rito do Amor Selvagem (a imensa bola de plástico no mar, o uniforme preto fascistóide do marido gordo), aparecem também o ator principal desta peça (Stênio Garcia), além de um dos maiores colaboradores e amigos de Agrippino à época (Jô Soares, que lembremos havia escrito uma das partes de Tarzan $I I^{\circ}$ Mundo) e do próprio Agrippino como o "falido transatlântico, náufrago do Titanic". Dadas estas constatações elementares, seria então preciso pensar mais profundamente a presença de Agrippino (e do Sonda) no cinema de Sganzerla. Certamente essa empreitada demandaria outro espaço (um artigo, por exemplo); me atrevo, no entanto, a deixar aqui três sugestões inciais: $1^{\text {a }}$ - A estrutura de um filme como Sem Essa Aranha, com seus longos planos-sequência de dez minutos de duração, me parece influenciada pela organização das cenas em ${\text { Tarzan } I I I^{\circ}}^{\circ}$ Mundo e Rito do Amor Selvagem que se pautavam por uma série de ações previstas (roteirizadas) que desencadeavam outras tantas ações acidentais na duração da cena. Uma peça como Tarzan tinha assim um conjunto de unidades cenográficas que mesmo se removidas ou invertidas numa apresentação não haveria decréscimo de sentido para as demais, exatamente como no filme de Sganzerla; $2^{\mathrm{a}}-\mathrm{Um}$ interesse maior pela materialidade e pela superfície dos corpos, assim como pela performatividade autônoma dos "acontecimentos" que encadeiam os filmes; $3^{\mathrm{a}}$ - A ideia da arte como um grande rito, menos no sentido da re(a)presentação mítico-religiosa (teatro de mistérios transcendentais) e mais como este grande e libidinoso abismu que sempre nos olha (e devora) de volta.

170 XAVIER. Cinema Brasileiro Moderno 
política no filme, ela deve estar aí, no seu horror ${ }^{171}$, e não em qualquer projeto crítico de transformação social. Se a arte-soma não rendunda numa nova arte pura, mas sim na desmaterialização conceitual da estética, o povo, que por definição contábil é o conjunto de todas as pessoas de um país, desmancha-se quando nos perguntamos: e o quê além dessa soma constituí o povo? Qualquer resposta mais profunda é posta sob suspeita na medida em que poderia significar uma recaída no "papai-mamãe" do constructo estado-nação. Aquilo que está caindo é aquilo mesmo que precisamos derrubar.

E o grande edifício que nesse caso explicitamente precisa ser derrubado é o Sentido - cuja mais bem elaborada expressão no cinema está na montagem intelectual tal como conceituada por Eisenstein, justamente porque foi o cineasta russo que, demonstrando uma ambição teórica superior aos seus contemporâneos, ampliou os horizontes do espectro fílmico ao apontar como o fundamento do cinema uma idéia abstrata (a saber, "o conflito") e não qualquer especificidade ou potencialidade que o novo meio teria frente as demais artes. Com Eisenstein o cinema ganha status de uma máquina produtora de um pensamento. Pois sabendo da grande influência do criador de Outubro sobre o criador de Terra em Transe (e, em última análise, o grande criador de todo o Cinema Novo), esses rebentos infames do udigrudi deveriam enfrentar o pai maior no seu próprio terreno (pai que, aliás, também já se revestia de "crueldade" em suas experiências mais recentes) propondo novas relações (anti)intelectuais de montagem. E aqui Hitler $I I I^{\circ}$ Mundo, como experimento de uma artesoma e um dos marcos primeiros dentre os marginais, cumpre papel fundamental.

$* * * * *$

171 Chris Marker em Sain Soleil cita a frase de Brando em Apocalipse Now "O Horror tem uma face... você precisa fazer do horror um amigo" e completa: "para expulsar o horror que tem um rosto e tem um nome você deve dar-lhe um outro nome e uma outra face". É o que faz Glauber (com sua estética da fome) em seus filmes - dá outro nome e outra(s) face(s) ao horror; torna seus personagens sujeitos do horror (da fome). Agrippino e Sganzerla parecem, pelo contrário, exigir que as figuras que percorrem seus filmes façam amizade com o horror deixando que este olhe de volta (através desses "furos" na montagem), com sua face imensa, para o público que o contempla (como a sensação que Marker tem ao passear por Tokyo de que todos os olhos dos gibis, grafites e televisores olham de volta pra ele quando vistos). 
Como unidades narrativas do filme, ao acontecimento do casal de classe média (desde a cozinha até a borracharia) segue-se o acontecimento do "parto cósmico", com o mesmo casal negro de Tarzan III ${ }^{\circ}$ Mundo. É perfeitamente possível identificar estas “unidades" deste modo, como acontecimentos: eles possuem uma mínima coerência narrativa explícita num conjunto razoável de elementos comuns (mesmas figuras, mesmo espaço de atuação, mesmas intervenções da banda sonora). Por outro lado, estes acontecimentos (unidades narrativas) são constituídos, muitas vezes, por outros acontecimentos que possuem um sentido em si mesmos. Vejamos, por exemplo, a "cena" do fusca, conforme descrita anteriormente - ela é parte desse acontecimento maior que é a aventura do casal de classe média (da cozinha até a borracharia), mas em si mesma não deixa de ser um acontecimento pleno (lembrando que a cena do fusca não se restringe a um único plano, desdobrandose em jump cuts), assim, a unidade mínima de "sentido" do filme de Agrippino é o acontecimento, sendo que este pode ou não ser parte de um outro acontecimento. Podemos até mesmo chamar de acontecimentos independentes muitas intermissões e ruídos da banda sonora - os monólogos, por exemplo - que assaltam frequentemente as imagens, ou até mesmo a própria fatura do quadro. Voltando ao fusca com o pneu furado, por exemplo, nele a performance da cena (a impostura do movimento num auto-móvel) se dá aos olhos pela construção dos enquadramentos que são eles próprios acontecimentos pois implicam numa performatividade do olhar que "joga" com a habilidade do espectador em compreender a "lingua" usual do cinema. Deixamos assim a semiótica rumo a uma pragmática do filme.

\footnotetext{
“A unidade da comunicação lingüística não é, como se tem geralmente suposto, o símbolo, a palavra, ou a frase, ou mesmo a ocorrência do símbolo, palavra ou sentença na execução do ato de fala. Considerar a ocorrência como uma mensagem é considerá-la como uma ocorrência produzida ou emitida. Mais precisamente, a produção ou emissão de uma ocorrência de frase sob certas condições é um ato de fala, e os atos de fala são a unidade básica ou mínima da comunicação lingüística. Um modo de compreender este ponto de vista é perguntar qual a diferença entre considerar um objeto como um exemplo de comunicação lingüística e não considerá-lo sob este ângulo. Uma diferença crucial é a seguinte: quando consideramos que um ruído ou uma inscrição numa folha de papel constituem, enquanto mensagem, um exemplo de comunicação lingüística, uma das coisas que devemos supor é que o
} 
ruído ou a marca foram produzidos por um ser, ou seres, mais ou menos semelhante a nós, e foram produzidos com certas intenções". ${ }^{172}$

Grande representante do pragmatismo filosófico americano, Searle parte do princípio de que falar uma língua é adotar uma forma de comportamento regido por um conjunto de regras reconhecível por qualquer falante (ele gosta de usar crianças como exemplo). É esse conhecimento comum das regras que permite a comunicação se fundamentar na execução de atos de fala, sendo que esta unidade da comunicação linguística (ato) é performativa: depende de certas regras (lógicas / históricas) e demanda certas intenções (subjetivas). Essa dimensão performativa da comunicação é aquilo mesmo a ser explorado pela cena (o happening do fusca no espaço tridimensional da cidade) e pelo olhar (o ato do filme que nos revela a única realidade que lhe interessa - aquela criada por ele) - a arte da performance nasce justamente deste delírio poético em relação a realidade performática dos atos. De maneira bem pragmática, posso considerar, por exemplo, que a "performance" adequada ao fusca (veículo automotor de combustão interna) nas suas condições normais de funcionamento seria 'pôr-se em movimento', projetando o corpo humano numa velocidade muito além dos seus limites fisiológicos, alterando sensivelmente sua economia pulsional e seu imaginário (aasim como a performance adequada ao quadro seria representar o movimento). O carro foi projetado para isso, para libertar o sujeito do flagelo do corpo: ele é a mensagem. Se o artista, pelo motivo que seja, transfigura esta condição, então temos uma intervenção (artística) no objeto, nos sujeitos (corpos) que nele estão e nos atos que eles deveriam realizar (perform). O carro, símbolo do movimento e da potência (e símbolo igualmente dos frutos da modernização conservadora e da sociedade de consumo), torna-se a própria impossibilidade do movimento, desejo subsumido, castração. ${ }^{173} \mathrm{O}$ que eu chamei de performance do olhar, por sua vez, talvez deva ser considerado um uso mais livre do termo.

“Em uma manhã de 1962, em Nice, cidade onde havia nascido trinta e cinco anos

172 SEARLE. Os Actos de Fala - p. 26/27.

173 Daí que a recauchutagem do homem da classe média é apenas o desfecho da perfomance, na medida em que o corpo humano, de tal forma dependente das suas extensões automotivas, quando impossibilitado de utilizá-las, torna-se ele próprio um objeto inútil - realização máxima da tecnocracia (fascista). 
antes, Yves Klein realizou um de seus trabalhos mais conhecidos: Salto no Vazio. Ele mesmo fotografado no instante que saltava para a rua, de um edifício - era o protagonista de sua obra, e, nesse sentido, a obra em si”. ${ }^{174}$ A fotografia de Klein é bem conhecida e considerada por muitos como a certidão de nascimento da performance art. Aceitemos, pois, a sugestão de Philip Auslander ${ }^{175}$ e comparemos esta fotografia à outra célebre imagem da história da performance e da body art: aquela que mostra Chris Burden levando um tiro no ombro, dado por um amigo, dentro de uma galeria de arte em 1971. Qual é a diferença fundamental entre as duas? Basicamente: sabemos que Burden foi realmente baleado no ombro naquele dia, mas Klein não "saltou no vazio" simplesmente sem nenhuma proteção (ou teria tido sério problemas!). Temos então, no primeiro caso, um caso clássico de registro documental; e no segundo? Não haveria uma dimensão performativa no próprio registro fotográfico de Klein? É o que sugere Auslander, propondo uma distinção entre a documentação de performance tipicamente "documentária" (relação tradicional) e um outro tipo que ele chamou de documentação "teatral" (que incluiria a foto de Klein). Neste segundo tipo, o registro é parte constitutiva da obra: aqui vislumbramos claramente uma performatividade do olhar. Vale agora um esclarecimento maior sobre os fundamentos dessa noção de performatividade.

"Eu os declaro marido e mulher": o que uma sentença como esta pode nos revelar (na saúde e na doença) sobre a natureza da língua? Nas famosas lectures realizadas em 1955 na universidade de Harvard, o filósofo inglês J. L. Austin, ligado a Escola Analítica de Oxford, propôs que em enunciados deste tipo, que ele chamou de performativos, "to say something is to do something", ${ }^{176}$ ou seja, em sentenças como esta pessoas não apenas representam, mas fazem/realizam (perform) atos - os enunciados performativos são, eles próprios, ações. Não demorou muito para Austin perceber que sua separação inicial entre enunciados constantivos (aqueles que, por descrevem um estado de coisas, se submetem a verificabilidade, sendo verdadeiros ou falsos) e enunciados

174 GLUNSBERG. A Arte da Perfomance - p. 11.

175 AUSLANDER, P. The Performativity of Performance Documentation. In: Journal of Performance and Art - PAJ 84 (Volume 28, $\mathrm{n}^{\mathrm{a}}$ 3), MIT Press, September -2006, pp. 1-10.

176 Essas conferências foram reunidas em livro: AUSTIN, J. L. How to Do Things with Words. Cambridge, Harvard University Press, 1962 (Não por menos, o livro foi traduzido no Brasil com o seguinte título: Quando Dizer é Fazer palavras e ação. Porto Alegre, Artes Médicas, 1990). 
performativos (aqueles que, por não descreverem nada, não se submetem a tal critério) era artificial, já que sempre seria possível transformar um enunciado constantivo em performativo. O passo seguinte seria declarar que todos os enunciados são performativos. ${ }^{177}$

Austin nunca aceitou que suas idéias fossem expandidas para além dos problemas específicos da filosofia analítica da linguagem. As ações dos enunciados performativos são aquelas do uso corrente da língua, completamente esvaziadas quando estes enunciados são utilizados de maneira parasitária ${ }^{178}$ (na poesia e no teatro, por exemplo). Há, no entanto, uma teatralidade (performativa) inerente a filosofia da linguagem de Austin se considerarmos que ela implica necessariamente numa "teoria da ação" (ramo da filosofia moral). Um ilustre precedente deste tipo de teoria pode ser encontrado na famosa cena do enterro de Ofélia em Hamlet: "An act hath three branches - it is to do, to act, to perform", diz um dos coveiros $(5.1: 11)$. O que nos ensina o CoveiroFilósofo é que uma ação pode ser dividida em seus atributos físicos ("do"), seus aspectos sociais (“act”) e suas qualidades teatrais ("perform”), notando assim que "qualquer ação conscientemente realizada (performed) refere-se a si mesma, é parte de si mesma" ${ }^{179}$, e que essas ações são instâncias de um comportamento construído socialmente e que este atua não sobre um palco, mas sim na "vida real" - eis o que se denomina performatividade.

Uma pensadora ligada a Teoria Feminista e interessada nas discussões sobre Sexo / Gênero como Judith Butler pode muito bem, então, explorar a filosofia de Austin sobre os 'atos de linguagem' num sentido teatral, na medida em que esses atos não se referem apenas a uma "relação verbal" entre pessoas, mas constituem um laço moral entre os falantes da mesma língua. "A realidade do gênero é performativa: o que significa, bem simplesmente, que ele é real apenas na medida em que ele é performado". ${ }^{180}$ Para Butler, o gênero é um ato que foi ensaiado, um roteiro que sobrevive aos

177 Austin propõe a partir daí ser possível distinguir em cada enunciado três atos simultâneos: locucionário (ato de enunciar lingüisticamente); ilocucionário (aquilo se realiza quando o enunciado é dito); perlocucionário (aquilo que se realiza não na linguagem, mas pela linguagem).

178 Ele deixa isso claro na "Lecture II" in: Opus Cit. 1962, p. 22.

179 SCHECHNER. Performance Studies: an introduction. - p. 141. Foi Schechner quem apontou a dimensão teorética presente na fala do coveiro shakespeariano.

180 BUTLER. Performative Acts and Gender Constitution:an Essay in Phenomenology and Feminist Theory - p. Butler confronta neste texto a tradição analítica de Austin com aquilo que chama teoria fenomenológica da ação, cujos expoentes seriam Husserl, Merleau-Ponty e George Herbert Mead, sem esquecer Simone de Beauvoir. 
atores que fazem uso particular dele, mas que exige sempre novos atores individuais para atualizar-se e reproduzir-se como realidade. É a Ideologia (as convenções sociais hegemônicas) que escreve as leis (históricas) do gênero, o que indica que estas podem ser alteradas por performatividades alternativas.

Toda performance art põe em prática teorias da performatividade utilizando diferentes tipos de materiais, especialmente os corpos no espaço tridimensional ${ }^{181}$ : o espaço da vida real. ${ }^{182}$ Por isso em Hitler $I I I^{\circ}$ Mundo, embora uma ou outra cena possa exigir a criação cenográfica de um espaço diegético, como na seqüência do "laboratório", dá-se preferência por intervenções no espaço do cotidiano (algumas delas, inclusive, contando com a participação de "espectadores" que se acumulam voluntariamente em torno da performance) - ao tornar um ato no espaço público "performativo", o real (e com ele categorias como "arte" e "imaginário") torna-se imediatamente um horizonte problemático, talvez apenas um das dimensões do possível. Com isso, suspende-se qualquer projeto de representação que visasse uma imagem justa do mundo (como aquele ligado a Brecht) através da identificação entre personagens e público (ou mesmo aquele que, distanciando esse processo, conseguisse revelar nele as estruturas subjacentes da vida social).

Agrippino nos propõe especialmente num filme como Hitler uma soma de “performances" que hora se coadunam, hora se repelem, numa criação de harmonias e de ruídos que nos colocam diante de um conjunto de acontecimentos. Este conjunto, no entanto, não compõe um acontecimento final, uma síntese orgânica capaz de acolhê-los num todo (nem mesmo como um promessa); o que une esses acontecimentos no filme de Agrippino é essa sensação amedrontadora de que o todo não tem nada em si (daí a estranha justaposição lacunar Hitler $I I I^{\circ}$ Mundo) - mas é só assim que ele se torna uma realidade vivida (na escritura): ao dizer o seu vazio, ele afirma uma nova plenitude (destotalizada). Desse modo, os acontecimentos em Hitler III $^{\circ}$ Mundo são um

181 Seu lema é "the personal is the political"

182 Se aplicarmos o termo retroativamente para os happenings de Kaprow temos a dimensão exata da ruptura espacial: Kaprow afirma que depois das colagens e das justaposições cubistas "era apenas uma questão de tempo antes de ser permitida a entrada no ato criativo de tudo mais exterior a pintura e a tela, incluindo o espaço real." KAPROW. Assemblage, Enviroments and Happenings - p. 165. 
desdobramento expandido dos scenarios abertos de Tarzan $I I I^{\circ}$ Mundo, dos cantos de PA e do parágrafos bissextos de LP.

É justamente essa performatividade das ações (e das imagens), aliás, o que permite a indepêndencia de um acontecimento em relação a outro: embora eles contribuam (como soma) para o sentido de um outro acontecimento, não são redutíveis a ele, são fragmentos que sempre subsistem como tais. Este cinema de happenings complica uma análise estrita da linguagem cinematográfica nesta obra (como, aliás, parecia ser mesmo a vontade) porque embaralha o velho anseio em descobrir qual o equivalente no cinema da palavra na literatura (ou pelos menos quais as articulações possíveis), dando-lhe uma dimensão mais abstrata - o cinema não somente incita problemas e reflexões filosóficas, mas ele próprio faz filosofia (torna-se pensamento). Tais ações performativas, tais acontecimentos encontrados em Hitler nos conduzem para além dos debates formalistas sobre o cinema como entidade específica, rumo a dimensão do cinema como o lugar mesmo de um modo de pensar. É nesse ponto fundamental que a montagem de acontecimentos encontra-se com a montagem de atrações de Eisenstein. Na abordagem que o teórico e cineasta russo faz do cinema nos anos vinte:

\begin{abstract}
"este não é afirmado, de início, como uma entidade específica, objeto preestabelecido, já constituído, e cuja especificidade (a essência) deveria ser definida, fundada. Ao contrário, o texto ${ }^{183}$ chega ao cinema como lugar de efetuação de processos ou fenômenos que o excedem, pertencentes à expressão e ao pensamento humanos. De certo modo, Eisenstein opera um descentramento do cinema como dado (parte do pensamento, da arte, da linguagem 'encontra' o cinema e toma novamente o rumo do pensamento abstrato e da linguagem), a fim de constituir seu objeto: o cinema intelectual." 184
\end{abstract}

Do mesmo modo que muitos de seus companheiros na vanguarda cinematográfica russa, Eisenstein também começou pensando o cinema a partir do teatro. A diferença é que enquanto, por exemplo, para Lev Kulechov a questão era basicamente descobrir as leis fundamentais da especificidade do cinema em relação ao teatro ${ }^{185}$, para Eisenstein o negócio é outro:

183 Trata-se aqui do texto teórico intitulado Stuttgart escrito inicialmente por Eisenstein em 1929 para ser apresentado numa conferência na cidade alemã homônima.

184 ALBERA. Eisenstein e o construtivismo russo - p. 270.

185 “Todos os tipos de arte possuem uma essência e nós devemos procurar essa essência no ritmo. Mas o ritmo em arte é expresso e alcançado de várias maneiras: no teatro através do gesto e da voz do ator, no cinema através da 
ele nos diz com todas as linhas que sua carreira no cinema começou, de fato, no teatro, mas não porque em sua encenação da peça de Ostrovsky Mesmo o mais sábio se deixa enganar no Teatro do Proletkult (Moscou, março de 1923) havia um curta-metragem cômico dirigido por ele, mas sim porque sua participação nela "levou para o teatro os próprios eventos - um elemento puramente cinematográfico, porque diferente das reações aos eventos, um elemento puramente teatral." ${ }^{" 186} \mathrm{O}$ cinema para Eisenstein é uma ação (choque) que já desponta como singularidade dentro mesmo do espetáculo teatral, portanto, ele não se define por seu material, mas sim por aquilo que provoca no interior do espectador (ele é pensamento).

O que Eisenstein quer dizer como esta "reação aos eventos" que seria, por excelência, o "elemento puramente teatral"? Ora, o que ele nos diz aqui, eu penso, é que no teatro o trabalho se centra no corpo do ator. Eisenstein parte de Meyerhold (de quem havia sido aluno e assistente e a quem chamou a vida inteira de mestre), de sua técnica biomecânica onde o intérprete deve dominar seu corpo assim como o operário é capaz de manusear a máquina. O grande encenador russo buscou sua vida inteira dar o passo seguinte na escala da arte da atuação: se Stanislavski (seu mentor-opositor desde os tempos em que Meyerhold era ator no Teatro de Arte de Moscou, participando inclusive da primeira montagem de A Gaivota de Tchecov) havia relegado o "ator tradicional" (as divas) ao segundo plano da individualidade, o submetendo ao jogo coletivo de uma equipe; Meyerhold excluiu completamente a iniciativa pessoal do artista em nome de uma dramaturgia da coletivização.

Partindo do "teatro da convenção consciente" criado ainda na primeira década do século XX (logo depois de sua saída do Teatro de Arte), apoiado no tradicionalismo da commedia dell'arte e do teatro japonês, Meyerhold cumpriu um longo e prolífico itinerário de pesquisas e processos cênicos até desenvolver sua técnica biomecâmica que se tornaria célebre no ambiente teatral russo pós-revolução. A idéia de um método de disciplina corporal que permita ao ator, 
construtivamente (palavra que despia a transcendência da forma contida no ideal purista da “composição" e aproximava o trabalho industrial do trabalho artístico), obter a expressão direta das emoções (e não sua "mera" representação) significava a própria superação histórica da mimese psicológica do teatro burguês (leia-se Stanislavski). Esse método fundamentava-se na primazia mecânica dos efeitos físiológicos - daí sua implicação mais evidente nas leis de estímulo e resposta, de conceber e de receber ordens, enfim, de ação e reação. É a isso que se refere Eisenstein quando chama a atenção para a reação como elemento puramente teatral: os atores "reagem" as emoções do personagem enquanto o público, por sua vez, reage as expressões do ator. O cinema pode ir além disso na medida em que, no choque entre diferentes atrações, faça o pensamento nascer diretamente no espectador, sem necessitar desse encadeamento de reações. ${ }^{187}$

Partindo disso, Eisenstein visa superar seu mestre, primeiro no seu próprio meio, depois nessa "arte maior" que seria o cinema. Isso porque nesse meio tempo ele se influenciou muito pelo excentrismo, um termo derivado das experiências realizadas pela Fábrica do Ator Excêntrico, uma companhia teatral de Petrogrado que ele conheceu em 1922. O "excentrismo" seria uma metodologia de desautomatização da percepção através da escolha dos momentos mais significativos, mais fortes e agressivos do espetáculo, e da nova relação possível que eles acabam entretendo em cena. Nas palavras de Albera "a tônica não é, portanto, a gestualidade, o corpo do ator; o que se quer, ao contrário, é encontrar uma certa dinâmica natural desse corpo, já que as articulações significantes ocorrem em outro nível, entre atrações." 188 A palavra fundamental neste trecho, para além das "atrações" destacadas pelo próprio autor, é "dinâmica" - a força dinâmica que resulta das relações substitui a mecânica da gestualidade; já não se quer que o ator obtenha certas emoções desejadas, mas sim que o espectador as obtenha. E para Eisenstein, isso é algo típico do cinema e que, portanto, só o dispositivo cinematográfico pode realizar de modo mais completo.

187 Meyerhold, como muitos outros russos de seu tempo, admirava a teoria reflexológica desenvolvida pelo fisiologista Ivan Pavlov que advogava a ideia do comportamento como uma cadeia de reflexos em resposta a estímulos exteriores, sendo que muitos desses reflexos seriam passíveis de serem condicionados. No limite, pode-se afirmar seguindo Pavlov que o ser humano não age, apenas reage (daí sua insistência em negar qualquer terminologia mentalista).

188 ALBERA. Opus Cit - p. 239. 
Pois se para o grande maestro do Potemkim o percurso racional na metade dos anos 20 era, portanto, partir do teatro para o cinema (é isso aliás que indica o título do seu artigo), em Hitler III Mundo, mais de quarenta anos depois, acompanhamos o processo inverso: aqui é o cinema que, no momento auto-reflexivo de sua maturidade como criação autoral, faz o caminho hesitante de "reinvenção" do teatro. Só que certamente este teatro ao qual se retorna (numa repetição transfiguradora) já não cabe nos termos aos quais o cineasta russo se referia a ele (basicamente, o dispositivo teatral da tradição), ele é agora o TEAT(r)O $\mathrm{O}^{189}$ - o fundamento mesmo de uma nova educação para a liberdade. Eisenstein já havia, de certa forma, intuído isso ao montar uma de suas últimas peças dentro de uma fábrica, utilizando a materialidade de suas instalações como espaço cênico $^{190}$ - esta dimensão física do espaço se impunha de tal forma que a "representação" parecia transmutar-se em "figuração" (uma espécie de interferência da ação na energia ambiente) - o que já apontava para uma outra lógica. Pois tanto para Eisenstein quanto para Agrippino o objetivo final me parece ser a abolição do teatro como instituição e, em última instância, a abolição da própria arte ${ }^{191}$, só que no caso do primeiro (em íntima relação com o construtivismo pós-revolucionário) a dimensão dessa abolição é produtivista, em nome da instrução das massas, enquanto no caso específico do Sonda (em íntima relação com a corrente contracultural dos anos 60), ela se faz em nome de um corpo redescoberto, ponto de partida para uma sociedade eximida de complexos e repressões.

Contemporâneo das experiências de vanguarda que pipocavam por todo o globo, o trabalho do Sonda rejeitava a ênfase do teatro tradicional no texto e na fábula propondo com sua arte-soma algo muito próximo, por exemplo, do theater of mixed means tal como descrito pelo crítico Richard Kostelanetz num artigo em $1968^{192}$. Seria assim o teatro, esse modo primeiro (e

189 Aproveito aqui a expressão cunhada pela Teatro Oficina que destaca os limites transitivos entre o teatro, as ações (morais) e o rito (te-ato).

190 Máscaras de Gás (1923-4), realizada dentro de uma indústria de produtos químicos (o enredo versava sobre um grupo de operários heróicos que arriscavam suas vidas para conter um grave vazamento tóxico, a despeito da negligência e da inépcia dos patrões burgueses, salvando assim a fábrica de um desastre de proporções gigantescas).

191 O Cinema, por suas próprias características, não seria assim uma "arte", pelo menos não no sentido oitocentista do termo, mas como a mais aperfeiçoada das máquinas de criar imagens, realização maior da era industrial, seria a própria visão construtiva das coisas - uma síntese (dialética) entre a arte e a ciência, capaz de oferecer "formas diretas para ideias, sistemas e conceitos, sem qualquer necessidade de transições e paráfrases". EISENSTEIN. Dramaturgia da Forma do Filme. In: A Forma do Filme - p. 70.

192 KOSTELANETZ. The theater of mixed means. London: Pitman, 1970. 
primitivo) do ver e do representar, esse moribundo renitente, que viria agora devorar pelas beiradas o gigante do século, o cinema, justamente no momento em que a euforia ontológica a respeito das imagens fílmicas parece fenecer frente a uma crítica radical dos efeitos do aparelho de base ${ }^{193}$ ? Vejamos este trecho do Welfare State Manifesto (1972) do grupo de teatro alternativo londrino homônimo (Welfare State) que pela clareza com que sintetiza muitas das propostas em voga naquele período merece a citação:

"make images, invent rituals, devise ceremonies, objetictify the unpredictable, establish and enhance atmospheres for particular places, times, situations and people. In current terminology we fuse art, theatre and life style, but we aim to make such categories and role definition in itself obsolete." $" 194$

Nesta idade da condição post-medium (ver nota 48 deste trabalho) a obra de arte encontra na teatralidade performativa seu centro de reflexão. Esse retorno do cinema ao teatro só pode acontecer como uma transitoriedade, uma fluidez entre os meios, com a diluição do discurso sobre suas especificidades: se por um lado há um interesse renovado pelos gestos e ações do ator, nem por isso a montagem deixa de ser o elemento intelectual (e fundamental) do filme. A performance cênica que ocorre em frente às câmeras é inseparável em Hitler III Mundo desta "performance do olhar", ao qual se unem os efeitos da montagem. Vejamos por exemplo essa outra outra unidade narrativa (acontecimento) de Hitler III ${ }^{o}$ Mundo que chamarei aqui de "complô contra Hitler".

Ela começa com uma seqüência de planos passados num laboratório: aparelhos eletrônicos e engenheiros cibernéticos, tudo envolto num clima levemente "pateta" entre os cientistas e seus inventos maravilhosos. De repente, entra pela porta um velho senhor vestido como um “jurisprudente", ${ }^{195}$ acompanha-o um homem com uma metralhadora, ao fundo (over) ouvimos uma voz: "o golpe de estado será conduzido pelo robô”. Percebemos, nos planos seguintes, exatamente do

193 BAUDRY. Cinema: efeitos ideológicos produzidos pelo aparelho de base in: A Experiência do Cinema (Opus Cit.) 194 Citado em CARLSON. Performance: a critical introduction - p. 106.

195 Com sua toga preta e peruca de tribunal, essa figura da legalidade, obviamente um tanto ridícula, é uma espécie de alegoria da ilegitimidade. Lembremos que em 1967, a "revolução democrata" de 1964 se institucionaliza outorgando uma nova constituição da República - encomendada a juristas de confiança dos golpistas. Há, igualmente, uma leve inspiração nos membros da Assembléia da Revolução Francesa, particularmente em Robespierre (a figura é interpretada pelo famoso ator e teatrólogo Eugênio Kusnet). 
que se trata: o jurisprudente, com uma maleta de dinheiro, contrata os serviços da Central de Inteligência para Golpes no Terceiro Mundo que lhe fornece um robô. Na seqüência seguinte, passada num edifício em ruínas, vemos o robô sendo programado (pelo jurisprudente e seu comparsa) para eliminar Adolf Hitler. Por fim, em franco tom de deboche, o robô mata a tiros todos os envolvidos na ação, inclusive uma moça que ainda não tinha entrado na história.

Boa parte dessas cenas possui uma franca dimensão performática: Hitler atirando melancolicamente tijolos de um prédio em ruínas que se espatifam no chão em migalhas (com a câmera apanhando tudo logo acima de sua cabeça calva), como quem brinca melancolicamente em meio as ruínas é um 'acontecimento'; um monólogo over chamando Adolf Hitler de "conservador democrata" enquanto o jurisprudente solenemente entra no laboratório com uma maleta de dinheiro e um livro de leis é um acontecimento; o robô fuzilando a queima-roupa e de forma abestalhada todos aqueles que cruzam a sua frente é um acontecimento, que por sua vez se fragmenta em "contra-planos" aproximados mostrando os corpos se contorcendo, cuspindo sangue pela boca, enquanto o som de tiros fora de sincronia reverberam ao fundo: eis um conjunto de acontecimentos. A todos esse acontecimentos é dada pelo menos uma definição em comum: cada acontecimento tem sempre um sentido em si mesmo. Ele pode muito bem ser entendido como parte de um outro acontecimento: os planos destes corpos baleados pelo robô são partes deste outro acontecimento que é o "surto do robô" (que por sua vez é parte desta unidade narrativa que é o “complô contra Hitler”) - mas, fundamentalmente, este plano de um corpo baleado, caído no meio da terra, numa construção abandonada, cuspindo sangue pela boca, é um acontecimento em si mesmo. ${ }^{196}$ É justamente isso o que diferencia o "acontecimento" da "atração" de Eisenstein (pelo menos tal como ela foi concebida até o final dos anos 20).

A montagem de atrações do cineasta russo definia-se então como "uma

196 Tanto é que uma moça, segurando nas mãos duas placas de isopor branco (que não possuem qualquer função dramática na história, apenas uma função cênica - ótica), surge em cena (lembrando que se tratava de um cenário deserto - para os mais curiosos, as filmagens se deram na Cidade Universitária da USP então ainda em construção), sem a menor explicação e acaba também baleada e morta. Muito a frente na montagem veremos um plano solto dela atravessando o viaduto do chá. A temporalidade da montagem não está subordinada a narrativa. Um acontecimento aspira sempre a ser puro presente, exatamente como um happening. 
abordagem autenticamente nova que altera de forma radical a possibilidade dos princípios de construção da estrutura ativa (o espetáculo em sua totalidade)", sendo "uma montagem livre de ações (atrações) arbitrariamente escolhidas e independentes" ${ }^{197}$, sua essência, portanto, é não significar absolutamente em si, mas “exclusivamente na relação, ou seja, na reação do espectador”. O propósito da atração é "produzir certos choques emocionais que, por sua vez, determinem em seu conjunto precisamente a possibilidade do espectador perceber o aspecto ideológico daquilo que foi exposto, sua conclusão ideológica final". ${ }^{198}$ Deleuze pode então caracterizar a montagem de Eisenstein como típica de um "concepção sublime de cinema" onde:

\begin{abstract}
"A imaginação sofre um choque que a leva para o seu limite, e força o pensamento a pensar o todo enquanto totalidade intelectual que ultrapassa a imaginação (...) o choque tem um efeito sobre o espírito, ele o força a pensar, e a pensar o Todo. O todo precisamente só pode ser pensado, pois é a representação indireta do tempo que decorre do movimento. Ele não decorre deste como um efeito lógico, analiticamente, mas sinteticamente, como o efeito dinâmico das imagens sobre o córtex inteiro. Por isso depende da montagem, embora resulte da imagem: ele não é uma soma, mas um produto, uma unidade de ordem superior" 199
\end{abstract}

A atração de Eisenstein tem parentesco de nascimento com os acontecimentos: essa dimensão do espetáculo, do circo, do music hall, o jogo vivo das paixões da cinematografia de atrações próprio do Primeiro Cinema. Alguns personagens do filme de Agrippino remetem diretamente a essa faceta trickster de certo comediantes do cinema mudo. Ambos igualmente partilham esta crítica à subordinação do teatro ao texto. Mas ao afirmar-se na sua própria crueldade, os acontecimentos de Hitler $I I I^{\circ}$ Mundo não partilham essa dinâmica do choque de filmes como $A$ Greve e O Encouraçado Potemkin. O cinema de Agrippino é um cinema de corpos que sonham, no sentido dado por Artaud:

\footnotetext{
"A pele humana das coisas, a derme da realidade, é sobretudo isso que o cinema lida. Ele exalta a matéria e a revela para nós em sua espiritualidade profunda, em suas relações com o espírito de onde ela se originou (...) Ele não se separa da vida, mas reencontra a situação primitiva das coisas. Os filmes melhores sucedidos nesse sentido são aqueles onde reina um certo humor, como os primeiros Malec ou os Carlitos menos humanos. O cinema constelado de sonhos e que dá a
}

197 EISENSTEIN, S. A Montagem de Atrações in: (org) XAVIER A Experiência do Cinema - p. 191.

198 EISENSTEIN. Idem - p. 189.

199 DELEUZE, G. Cinema II: A Imagem-Tempo - p. 191. 
vocês a sensação física da vida pura obtém seu triunfo no humor mais excessivo. Uma certa agitação de objetos, formas, expressões, só se traduz bem nas convulsões e sobressaltos de uma realidade que parece se destruir a si mesma com um ironia na qual ressoa o grito dos confins do espírito." 200

Esses "Carlitos menos humanos"201 são figuras que espalham a morte por todo o filme: a angústia do corpo (a tortura espreita por todas as brechas); mas, ao mesmo tempo, no seu humor mais baixo e grotesco, pelo afloramento de seus desejos, tornam seu próprio corpo uma obra: a carne viva (o teatro) como rito (e portanto passagem) da morte. Eis um cinema da carne. Contra uma arte que é um "comprazer-se em perder o mundo" a solução é compreender que "crer não significa mais crer em outro mundo, mas num mundo transformado. É apenas, simplesmente crer no corpo. Restituir o discurso ao corpo, e, para tanto, atingir o corpo antes dos discursos, antes das palavras." 202 A arte-soma é também uma arte-corpo, na medida em que o termo soma nos remete igualmente ao genitivo grego somatos, o corpo, aquela substância que se opõe a alma e ao espírito. Não se trata aqui, no entanto, de uma volta aquela concepção dos anos 20 e 30 que tinha o corpo do ator (e, no cinema, a montagem fílmica) como a expressão máxima do ritmo orgânico, essência de toda arte. Pelo contrário.

Há, de fato, um outro corpo que o filme de Agrippino faz nascer, um corpo anterior aos corpos, inumano, um corpo que só esse olhar imenso das próprias coisas, a montagem, pode fazer brotar no espectador. Eisenstein, assim como Vertov, afirmava que o lugar mínimo da articulação fílmica acontecia entre planos (ele acreditava inclusive que essa articulação acontecia mesmo entre dois fotogramas!), isso significando que uma síntese orgânica das atrações deveria ocorrer no intelecto do espectador estimulado pelos choques da montagem, uma síntese que revelaria, para além de qualquer automatismo, o conflito como conceito fundamental do entendimento. A

200 ARTAUD, A. A Concha e o Clérigo. In: Linguagem e Vida. p. 161.

201 Num outro sentido, foi também o chaplinismo o que aproximou brevemente Meyerhold das idéias de seu pupilo: "desde a chegada do chaplinismo, me encontro mais inclinado nas obras teatrais a usar a chamada essencial das associações que Eisenstein cultiva especialmente.” (MEYERHOLD. Chaplin y el chaplinismo. In: Textos Teóricos v. 1 - p. 311) Aquilo que os afastava, segundo o próprio Meyerhold, era o gosto de Eisenstein pela tragédia, seu afastamento do jogo lúdico das formas mais populares e sua insistência na dimensão intelectual da montagem. Mesmo com suas qualidades, o cinema nunca deixou de ser para o encenador russo esse "quadrilátero odioso" que amofinava as idéias do criador.

202 DELEUZE. Cinema II: A Imagem-tempo - p. 208. 
montagem de acontecimentos de Hitler III $^{\mathrm{o}}$ Mundo, por outro lado, se interessa por esse entre como um "fora", uma brecha irreconciliável - é por essa brecha que vai brotar (no espectador) não o conflito, mas esse (anti)conceito de um verbo (um corpo) sem articulação, sem qualquer defecação (Deus!), enfim, a própria dimensão do impensado.

Se esse cinema retorna ao teatro ${ }^{203}$ é porque o corpo torna-se novamente o centro das intensões e atuações (o corpo figural do ator; o corpo violentado do espectador). A questão, no entanto, é que esse corpo aqui não pode ser reduzido nem a sua dimensão psico-física (um corpo de gestos e desejos); nem a sua dimensão ideal (o corpo-pensamento nascido da montagem) - ele é aquilo mesmo que se transubstancia continuamente de uma a outra. Volta-se ao teatro como o horizonte de uma arte-soma porque agora se acredita que ele é "a mais elevada idéia que nos reconcilia filosoficamente com o devir" - só que esse teatro outro se realiza agora como um cinema de acontecimentos; portanto, ele nada mais é (no horror de suas figuras e de sua montagem) do que "uma espécie de demonstração experimental da identidade profunda entre o concreto e o abstrato." ${ }^{204}$ Essa volta ao teatro não significa no entanto, em nenhum momento, um afastamento do cinema (do cinematográfico), justamente porque é o cinema que parece levar essa identidade profunda a outras dimensões, na medida em que apenas ele é capaz de operar um tipo de mineralização dos corpos à paisagem, ao espaço. Por este cinema, as perfomances, na fragmentação e na violação das figuras, assim como na repetição e na desarticulação do movimento, espalham a pulsão de morte, avançando sempre na direção da dissolução do sujeito; mas, por sua vez, a montagem desses acontecimentos, surpreendentemente, recoloca a dimensão narrativa (e o sujeito) como esse movimento (criador) de retorno ao corpo maternal e mudo. ${ }^{205}$ Percebemos pois que é na franja ruidosa das relações entre

203 Um teatro para além do drama, "com uma dramaturgia que produz estruturas antes parciais que totais". Realiza-se assim "o sacrifício da síntese para alcançar a densidade de momentos intensos. Se a partir das estruturas parciais se desenvolve algo como um conjunto, isso já não se organiza segundo modelos previamente dados pela coerência dramática ou de referências simbólicas abrangentes, não realiza síntese alguma. Essa tendência é válida para todas as artes. O teatro, forma artística mais radicalmente ligada ao acontecimento, torna-se um paradigma da estética. Ele deixa de ser o setor institucionalizado que era e torna-se o nome de uma prática artística de desconstrução multimedial ou intermedial do acontecimento instantâneo." LEHMANN. Teatro pós-dramático - p. 139.

204 ARTAUD. Cartas sobre a Linguagem. In: O Teatro e seu Duplo - p. 128 e 127 (respectivamente).

205 Não é à toa, portanto, que o último trabalho no cinema de Agrippino, o curta super-8 Céu Sobre Água (1978), seja justamente uma espécie de rito fílmico de (re)nascimento e retorno ao ventre materno. Vide a breve análise no capítulo final deste trabalho. 
perfomance e teatralidade (no cinema) que Agrippino inventa e sustenta sua arte-soma.

\section{$* * * * *$}

Logo acima refleti sobre de que maneira essa performatividade dos atos de fala podiam ser consideradas num sentido teatral nas muitas "atuações" exigidas pela vida cotidiana, pelos laços morais da lingua. Aqui, o termo performance ganha um alto parentesco com uma idéia mais expandida de teatralidade. Essas atuações performativas, no entanto, quanto mais vão se popularizando nas artes dos anos 60, acabam tencionando o próprio teatro como este conjunto de práticas, técnicas e costumes que reconhecemos como as artes do palco, dando origem a um tipo novo de arte perfomática cujo mote fundador é justamente declarar o teatro uma forma decadente. ${ }^{206} \mathrm{~A}$ artesoma de Hitler III Mundo nasce precisamente nesse momento de transição / transcriação de formas; o fundamental, no entanto, é que vemos tudo isso a partir do cinema, que acaba, como no poema de Drummond, sendo a resultante de toda a discussão mesmo sem ter propriamente entrado na história é verdade que apenas para percebermos imediatamente em seguida que ele está, de fato, comprometido até a raiz com a natureza do debate.

Uma genealogia das perfomance arts desnuda-se a partir do surrealismo e do dadaísmo chegando até os happenings de Kaprow e as manifestações do grupo Fluxus - é bastante comum aos pesquisadores deste campo identificá-lo como parte desta tradição conhecida como as "artes plásticas"; suas relações com o teatro, por outro lado, são sempre ontologicamente mais espinhosas. ${ }^{207}$ A dimensão pictórica dos happenings, por exemplo, é insistentemente proposta por

206 Sobre a questão: FERÁL. La performance ou le refus du théatre (bibliografia).

207 Um pesquisador como Auslander em seu trabalho From Acting to Performance investiga mais de perto os discursos sobre atuação em grandes "mestres" do teatro como Stanislavski, Brecht e Grotowski, para concluir que, ao contrário de algumas reflexões que colocam principalmente os dois últimos como precursores imediatos da Performance (Brecht pelo distanciamento proposto entre ator e personagem; Grotowski pela auto-exposição reificada, pelo sacrífico do ator que convidaria o público a fazer o mesmo, num confronto profundo consigo mesmo), estes operam em outro registro filosófico, ainda muito dependente de conceitos como o "self" e a presença, distinto daquele onde a Performance floresce como expressão artística (justamente aquele ligado a uma crítica radical destes conceitos - a argumentação de 
Kaprow em seus escritos. Para ele, os happenings nada seriam além da continuidade lógica das rupturas espaciais propostas pelas colagens e justaposições cubistas: "era apenas uma questão de tempo antes de ser permitida a entrada no ato criativo de tudo mais exterior a pintura e a tela, incluindo o espaço real." ${ }^{208}$ Essa pictorialidade dos acontecimentos é investigada por Agrippino em algumas sequências de seu filme.

Na principal delas, vemos um barco colocado às margens de um rio (o tietê); nele, uma dezena de figuras se agitam em convulsão. Um segundo plano nos mostra então, mais de perto, uma figura adormecida na proa do barco. Voltamos ao quadro anterior num terceiro plano, percebemos logo que uma das figuras em convulsão no barco tenta acordar o homem adormecido na proa. Subitamente, este se levanta e salta do barco, andando pela lateral esquerda do quadro até sair de campo. Suas roupas e gestos nos confirmam uma intuição: trata-se de Jesus Cristo andando sobre as águas, numa citação da famosa passagem dos evangelhos. As figuras agitadas no barco são os apóstolos (entre eles, algumas bizarrices, como um homem-inseto e um soldado nazista) - ou pelo menos um deles certamente é Pedro, pois este se atira ao mar e, como na "fábula", afunda no oceano por sua incredulidade até que Cristo venha restitui-lo sobre as águas (e em sua fé).

O que nos interessa aqui é que tal encenação bíblica, bem ao gosto de Agrippino (já vimos isso em Panamérica), faz igualmente uso de toda uma iconografia da tradição renascentista. Pensemos no primeiro quadro da sequência, o plano do barco "à deriva": nele as cabeças das figuras que se agitam ocupam justamente o espaço central da tela, aliás delimitada em duas metades pelo rio tietê. Na metade de baixo, a imanente, temos um primeiro plano (pictórico) vazio, só com areia e impurezas (o olhar deve se afastar das bordas inferiores, que aliás mantém a distância necessária a decência da contemplação) e temos o barco num segundo plano, mais centralizado (o plano da ação). A organização do espaço nos lembra assim, por exemplo, a Santa Ceia de Da Vinci. Na metade superior, a transcendente, a coisa fica ainda mais interessante. Levemente acima da metade do quadro,

Auslander, de modo claro, constrói-se tendo por base a crítica desconstrutiva de Jacques Derrida). Assim, nas performances, ao contrário do teatro desses mestres, “o sentido é produzido pela ação de algo que não está presente, que existe apenas como uma ausência.” in: AUSLANDER. From Acting to Performance - p. 28 (tradução minha). 208 KAPROW. Assemblage, Enviroments and Happenings - p. 165 (tradução minha). 
num espaço talvez ocupado justamente pela linha do horizonte, vemos (sobre uma ponte) uma das vias da Marginal Tietê, com seu fluxo de veículos em incessante movimento; enquanto no último plano superior, ao longe, no mais sagrado dos espaços dramáticos, vemos um os prédios da cidade encobertos por uma névoa esfumaçada.

O choque entre a sacralidade da citação bíblica (e a eloquência de sua representação pictórica) com a vulgaridade e a materialidade da encenação (a bizarrice das figuras, a podridão do rio-esgoto, a cidade verticalizada ao fundo) provoca de imediato um forte efeito paródico. Essa "paródia", no entanto, é mais sofisticada do que o deboche inicial nos faz crer. Chamo a atenção para um segundo momento (quadro) desta mesma sequência. Logo depois de Jesus sair de campo pela borda esquerda, vemos os apelos de Pedro e seu salto ao "mar". A câmera então (num outro plano) nos mostra Jesus interrompendo sua marcha e se voltando, provavelmente ao ouvir os apelos de seu discípulo. No momento em que Jesus se vira, o quadro o apanha em plano médio, numa das composições mais inspiradas do filme. Pela maior proximidade do enquadramento, a via expressa da Marginal Tietê ocupa agora o centro (baixo) do quadro, exatamente naquele espaço onde poderíamos imaginar o ponto de fuga da perspectiva monocular. Jesus, por sua vez, está levemente deslocado para a metade direita do quadro, isso porque, no canto superior esquerdo, ao fundo, organizando toda a composição, vemos uma alta chaminé industrial soltando fuligem. Dessa forma, se fizermos uma leitura do quadro segundo as "regras" do espaço fechado da representação clássica, a chaminé ocupa justamente o lugar do numinoso que numa diagonal dramática descendente irradia sua força transcendente (além de industrialmente fálica, pela forma alongada da chaminé) para a figura do Cristo - a fumaça da máquina urbana torna-se o signo da espiritualidade numa era da teologia fabril.

Mais interessante ainda que essa classicidade dramática das diagonais de força do quadro é o caso da "linha do horizonte" ocupada pela via expressa (que se prolonga nos quadros seguintes - um deles "reconstituindo", num plano aproximado, a famosa cena da Capela Sistina de Michelangelo "A Criação de Adão"), isto porque ele é o feixo exato onde o cinema encontra-se com a pintura. Se a constituição da perspectiva monocular (a partir do ponto de fuga) já "naturaliza" a 
dimensão do movimento no quadro, ela o faz justamente em nome de um instante pregnante, daquela epifania que só a contemplação unitária e estática de uma pintura pode proporcionar. Pois Agrippino, ao recortar tal enquadramento, em todo seu apelo clássico bíblico, com uma linha do horizonte marcada pela via expressa (e os créditos aqui também devem ser dados a Jorge Bodansky, seu diretor de fotografia e câmera), introduz justamente o movimento incessante, o devir, no espaço do numinoso - o cinema, com sua capacidade de "solubilizar" a obra pictural na percepção natural ${ }^{209}$, investe-se como a redenção da pintura sempre afeita a fruição sublime e ex(s)tática. Lembro aqui do belo curta de Pasolini, A Ricota (1963), em que a exigência de imobilidade feita aos atores para a reconstituição maneirista de quadros da tradição é sempre vilipendiada por detalhes do cotidiano da produção (instantes banais): seja a entrada de um negro no quadro, seja o riso faceiro de um dos participantes do tableau (que desmobiliza a atenção), seja o dedo no nariz de um figurante. O cinema ocorre sempre nos entreatos, na duração (como a vida). Assim, esse maneirismo pictórico, essa volúpia do sublime na imagem única, é associado no filme a um prazer das elites (a ideologia da estética), enquanto o cinema, essa arte do movimento e da reprodução técnica, está associado a "baixeza" das manifestações populares: o figurante, o bom ladrão, que se empaturra com a ricota (o grotesco dos banquetes da cultura popular descrito por Bakhtin) e morre durante as filmagens, aparece muitas vezes no filme em modo acelerado, incitando a comicidade típica do cinema mudo. Filho do neorealismo, Pasolini identifica o cinema com as classes populares (daí seu Evangelho Segundo Mateus, filmado logo em seguida, só com atores amadores e com uma quantidade exaustiva de closes de rostos do povo - eis o evangelho do cinema).

Tendo assim sua "origem" na pintura (Kaprow costumava chamar o que fazia de teatro de pintores), mas como uma ruptura derradeira com os limites da tela, os happenings voltam no filme de Agrippino a habitar o quadro, mas "expurgados" de sua pictorialidade (e mesmo de sua teatralidade) pelo cinema, que apresenta, de um modo ou de outro, seu espaço sempre como uma "realidade", como uma dramaturgia da natureza ${ }^{210}$. Por isso Hitler $I I^{o}$ Mundo é o ponto fulcral de uma 209 BAZIN. Cinema e Pintura. In: O Cinema: Ensaios - p. 175.

210 BAZIN. Teatro e Cinema. In: Cinema: Ensaios - p. 152. 
arte-soma, porque nele as artes se imiscuem (e se reverberam) umas nas outras: a teatralidade torna-se performativa; a performance, por sua vez, envereda por um "teatro de imagens" francamente pictórico enquanto a pintura redime-se na "mineralização" perceptiva do cinema e o próprio cinema faz a crítica de sua representação pura por meio de uma volta ao teatro.

É nítido, por exemplo, que não há trucagens excessivas ou excessos de montagem nas imagens de Hitler $I I I^{\circ} M u n d o^{211}$. Nele, a presença corporal, a releitura do espaço através do corpo do ator é imprescindível. A cena depende dos estados corporais dos intérpretes e seus corpos estão presentes no material que é orquestrado: tudo parece constituir-se como no "teatro", mas qual teatro seria esse? É famosa a máxima de Bob Wilson de que suas peças nada mais seriam do que uma junção de cinema mudo e peça radiofônica - pois é justamente esse o caso de Hitler (lembrando que nele as personagens quase nunca falam ou dialogam, e que a banda sonora do filme aparece, muitas vezes, como uma emissão radiofônica - ouvimos até a mudança de estações e a dessintonização de canais). Isso porque ao assumir qualquer espaço arquitetônico como locação, o corpo como figura (e não como personagem) e o texto como modo sem qualquer privilégio dentro da encenação, esse novo teatro optou por uma "escritura do visível" que toma o cinema por paradigma. Sem contar que a figura do encenador (e Bob Wilson é o seu grande representante) talvez fosse improvável sem o cinema (se é que tal suposição seja algo mais que um puro absurdo epistemológico) na medida em que é o cinema que cria o espectador como um encenador de imagens, já que a palavra imaginário só parece ganhar substantivação com o advento do cinema ${ }^{212}$, dando margem a idéia de que alguém possa organizar, no palco, imagens para a fruição de um outro. Cinema e teatro se reencontram no momento em que ambos lutam para se livrar do drama.

Para Bazin, por exemplo, o cinema já se diferenciava do teatro porque o espaço

211 O modo de produção também definiu essa opção estética: Hitler foi feito com sobras de filme de outros trabalhos (surrupiados pelo próprio Bodansky). Assim, criou-se essa opção por filmar sem pausa até o limite do rolo. Mas o mais importante é que, não sendo um "homem de cinema", Agrippino não separava as funções produtivas de realização de um filme (filmagem, montagem, edição de som) - ele já ia montando e experimentando as edições possíveis durante as filmagens (mesmo porque ninguém sabia se o filme seria montado).

212 Nas palavras de Denis Guéron, o cinema atribui uma consistência ótica ao imaginário do espectador através do efeitocâmera. GUÉNOUN. O Teatro é necessário? - p. 118. 
nele apresentado era o real, o mundo, a natureza e não a sua representação; na fenomenologia baziniana, o teatro era o lugar do dramático, da convenção, onde a representação nunca desaparecia. ${ }^{213}$ Só que com esse novo paradigma das artes performativas, pós-dramáticas (para ficar nas denominações conhecidas), da passagem dos anos 60 para os 70, tanto o cinema contestou-se como o espaço do natural quanto o teatro como o espaço da representação. Ambos passam então aqui a se apoiarem numa poética de acontecimentos, de eventos, que destituí sempre as certezas relacionadas a lógica profunda do drama (como aquela estrutura que diante de um mundo confuso e caótico traz para o ser um ordenamento interno que isola os sentidos criando uma totalidade da ilusão) apresentando-se como uma abertura para o incomensurável. E essa abertura se dá nas entranhas dessa dimensão narrativa (a temporalidade da ação, da montagem) que o cinema e o teatro trazem em comum e que os afastam, por exemplo, da pintura. ${ }^{214}$

Mas é interessante notar também que essa abertura retoma questões e problemas que já haviam sido apontados na esfera pictórica, e é a partir deles que a essência do filme transfere-se de um diálogo interpessoal para um diálogo entre homens e objetos que traz ao mundo o inominável dessa relação. Pensemos, por exemplo, em como um cineasta como Godard, ainda nos seus filmes pré-68, se relaciona com a pintura (e com a cor) em seus filmes. Se as pinturas de Renoir, espalhadas em pôsteres baratos (reproduções) pelas paredes do quarto de Patrícia em Acossado ganham novo alento como (pre) figurações da própria Patrícia e sua beleza desfraldada no espaço cinético da vida, aquilo mesmo que só poderia ser-nos oferecido pela verdade da objetiva, num evidente elogio baziniano à capacidade do cinema em excitar a pintura, em dar-lhe vida salvando-a da decadência intrínseca a sua musealização precoce; já no seu primeiro filme colorido, Pierrot le Fou, as coisas se complicam, como mostra a cena inicial onde uma narração over discorrendo sobre as qualidades da luz em Velásquez é sobreposta a uma partida de tênis. Em Pierrot le Fou, a experiência com a cor leva Godard ao limite de sua "aposta" no cineasta como a novo e grande pintor da vida moderna, algo que já em Duas ou Três Coisas que Eu Sei Sobre Ela aparece com uma certa desconfiança tenuemente 
melancólica.

Lembro, no segundo destes filmes, a cena em que vemos Mariana Vlady numa janela tendo Paris ao fundo. A voz do próprio Godard na banda sonora nos descreve a imagem, ele nos diz algo como "ela está usando um suéter azul”. Olhamos o azul de sua blusa, mas o que vemos não é nem o azul do objeto, nem o azul descrito, pois o cineasta (pintor) nunca imita o visível, o que ele faz é tornar visível. É no espaço entre a linguagem (a descrição verbal do suéter) e a imagem (o azul fotografado) que revela-se o olhar, e é o olhar o que interessa ao pintor (cineasta) e não tanto a imagem em si. Ao pintar o visível, o artista nos revela imediatamente o invisível, eis um tema central da fenomenologia de Merleau-Ponty, a idéia de que a visão do pintor é um nascimento continuado: "eu teria muita dificuldade em dizer onde está o quadro que olho. Pois não o olho como se olha uma coisa, não o fixo em seu lugar, meu olhar vagueia nele como nos limbos do ser, vejo segundo ele ou com ele mais do que o vejo." ${ }^{215}$ Parece ser este o grande mote para Godard continuar "fazendo cinema": ver não as coisas, mas através das coisas, entre as coisas. Jacques Aumont destaca justamente este "entre-as-coisas" como o motivo pelo qual aparece no início de Pierrot le Fou os famosos trechos do ensaio de Elie Faure sobre Velásquez que destacam o fato de que depois dos cinquenta anos, o pintor espanhol não mais pintava as coisas definitivas, mas o espaço acerca (entre) das coisas. ${ }^{216}$

Esse espaço do "entre-as-coisas" se relaciona diretamente com aquelas aberturas e fissuras da montagem (da narrativa, da lógica do reconhecimento). Portanto, se os happenings são, de fato, um teatro de pintores, e se o filme de Agrippino é, de fato, um cinema de acontecimentos, então as fissuras do visível se explicitam a partir dessa idéia maior de teatro (e de pintura), aliás, de desmistificação do sujeito da teatralidade. Talvez seja nesse sentido, aliás, que devamos considerar a marginalidade em Hitler III ${ }^{\circ}$ Mundo. Um Cinema Marginal não de imediato por estar à margem (dos gostos, da produção, da sociedade), e nem tanto por seu apelo e reconfiguração das figuras do crime (seja marginal, seja herói), mas sim por afirmar a margem como o que há de mais 215 MERLEAU-PONTY. O Olho e o Espírito - p. 18.

216 AUMONT. Opus Cit. - p. 226. 
oculto e ativo no sujeito: aquilo mesmo que permite a transitoriedade, o processo sempre recomeçado de constituição do sujeito. No caso do Godard pré-68, por exemplo, há uma afirmação das margens da imagem no sentido de uma sondagem de certa essência (extra)ordinária do cinema. É dessa forma que ele utiliza de forma reiterada tanto em Pierrot quanto em Duas ou Três Coisas as cores primárias justamente para nos remeter à constatação de que as cores do filme não são simulacros das cores da natureza, mas são a própria dimensão da cor, um aproximar-se do coração das coisas que o uso das primárias destaca como um retorno a esta alegria infinita dos começos, a materialidade primordial das identidades. Godard nesse momento é, sem dúvidas, o mais moderno dos cineastas (pintores). No caso do filme de Agrippino, temos uma dimensão mais escatológica: esse aproximar-se do coração das coisas é uma grande viagem ao coração das trevas do sujeito (mal) constituído do terceiro mundo... o horror.

No emaranhado de acontecimentos de Hitler $I I I^{\circ}$ Mundo, reconhecemos que a montagem de Rudá de Andrade ao menos incita um esboço de enredo: fracassada a aposta no robô para executar o golpe de estado (lembremos da cena em que ele surta e sai atirando para todos os lados), percebemos que uma figura masculina vai despontar nas ameias do filme: de início, ele é um dos cientistas responsáveis pela criação do robô (teria sido o surto uma armação?). Há sugestões de que ele faça parte de uma organização clandestina (da qual participa também $O$ Coisa!). Pois ele acaba preso, torturado e enviado para um sanatório onde uma mulher das classes altas (personagem interpretado por Ruth Escobar), que recorre pessoalmente a Hitler para convencê-lo a dizer o paradeiro do desaparecido, acaba por resgatá-lo. Numa das últimas cenas do filme, esse homem reaparece sendo "diplomado" pela mesma organização que havia contratado os serviços do robô. Percebemos então a proposta: muito mais viável que um exército de robôs é um exército de homens no qual o arbitrário está inculcado. A maneira mais explícita de fazê-lo é através da tortura, como o filme deixa claro - mas não só. Daí entendemos o papel chave do acontecimento passado na emissora de TV, nos bastidores do programa Silvio Santos: a TV é a grande arma de fascistização em massa dos tempos modernos. Em Hitler III ${ }^{o}$ Mundo portanto, e digo novamente, não se trata da ameaça de um 
novo fascismo ressurgido na América do Sul, mas da persistência das estruturas nazi-fascistas dentro

mesmo da democracia de massas. Hitler, reduzido no filme a uma figura cômica de histórias em quadrinhos, lamenta as dificuldades de governar a plebe indômita lendo gibis no café da manhã, enquanto mantém uma relação de submissão homoerótica com um homem sinistro (leitor da revista Fatos e Fotos) que enrola sobre o sexo uma toalha com a bandeira americana. Agrippino interessa-se pela dimensão anárquica e libertária da cultura pop, mas nem por um instante nega seu parentesco estrutural com o discurso autoritário. ${ }^{217}$

Voltemos então ao acontecimento na TV. Tudo se passa nos bastidores de um desses programas de auditório (SS) onde se dá um concurso de bizarrices: a mulher mais baixa, o homem mais gordo, a pessoa mais feia... A cena é cômica: o ator Túlio de Lemos, ele próprio um homem alto demais para os padrões, interpretando uma espécie de produtor de TV, parece fugir apavorado de uma anã que deseja participar do programa. Sua voz (over) recita um monólogo desencontrado e sentimental sobre um encontro casual acontecido certa feita, na saída de um cinema, com Getúlio Vargas, que logo depois partiria de olhos baixos rumo a seu famigerado destino! Todo o discurso é muito bacharelesco, artificioso, destacando mais o tom excessivamente grave de sua voz do que o sentido das palavras, de modo que nos perdemos no meio dessa ruminância fonética e acabamos desistindo de entender qualquer coisa - só nos restam algumas frases soltas que explodem fugazmente

217 Notamos assim que a relação de Agrippino com a pop art americana, particularmente com Warhol, possui também suas ambiguidades. Embora nutra um fascínio pela beleza asséptica das imagens do artista novaiorquino, ele não pactua com o pragmatismo do americano em relação ao destino desta nova civilização de imagens. Há sim, em Hitler, uma mácula no sujeito da experiência a ser lamentada. Talvez por isso o Agrippino dos anos 70 vá se distanciar um tanto do imaginário pop rumo a redescobertas místicas (e antropológicas) do sujeito a partir daquele eu que só pode ser um outro, algo muito presente na sua produção super-8. Creio que suas relações com o tropicalismo, pelo menos daquilo que podemos chamar de tropicalismo na canção a partir do disco-manifesto de 68, seguem uma ambiguidade semelhante. É notável o comentário de Agrippino, relatado pelo próprio Caetano, de que a única coisa que lhe havia interessado no disco manifesto (Panis et Circensis) eram os mutantes; ou seja, todo esse imaginário epifânico e rebarbativo da cafonice (no disco, encarnado, por exemplo, pela reinterpretação de Coração Materno de Vicente Celestino), que Caetano invoca sempre com muito deleite a partir de certa nostalgia do presente, não é parte tão importante do repertório poético de Agrippino. O passado de uma ilusão, o arcaico, lhe interessa mais como ruína, como resto, do que como oposição constitutiva (ao moderno). A releitura desses arcaísmos sob a luz dos imperativos tecnológicos ultramodernos seria então o próprio cerne da brasilidade tropicalista, que se apresenta assim como uma nova etapa na "linha evolutiva" do projeto nacional-popular, algo que não interessava a Agrippino, que, como bem percebeu Caetano, parecia estar há anos luz daquela discussão toda, e isso por uma razão simples: Agrippino sempre se desembaraçou mais facilmente (e mais naturalmente) das dicotomias do pensamento social cepalino (e do PC) do que os tropicalistas baianos que, afinal, haviam se formado nos quadros da esquerda universitária, da Bossa Nova e do Cinema Novo. Panamérica talvez tenha sido a primeira tentativa no Brasil de se escrever um livro sem passado. 
em nossos sentidos. Num segundo momento dá-se o encontro de Túlio (o produtor) com a anã. A voz over reaparece. Agora Túlio se diz interessado pela solidão dessa gente pobre e abandonada, buscando dar voz as aflições da anã ${ }^{218}$ (lembremos que ele trabalha num destes programas que recebe muitas cartas com pedidos de ajuda). Túlio chega então aos extremos da emoção verborrágica ("seu tamanho não representa nada aqui, o que existe é a grandeza do seu espírito, a inteligência do seu cérebro"). Nesse jogo de limites e desproporções, seja na sentimentalidade esquizofrênica da fala, seja na moldura dos corpos (o homenzarrão $\mathrm{X}$ a anãzinha), o que desponta é o bizarro das formas e dos atos.

Todo o filme de Agrippino está, de fato, entrecortado por imagens do grotesco. Já em Lugar Público elas aparecem de forma pontual, ganhando depois destaque em longos trechos de PA: a cena do banquete de bois entre os gigantes Carlo Ponti e Joe Di Maggio na bolsa de valores, por exemplo, é sintomática desse grotesco. O banquete aparece ali não apenas como uma figuração da volúpia do capitalismo financeiro, mas como afirmação do caráter popular e épico do livro de Agrippino em que essa aspiração a abundância choca-se com a cupidez da representação burguesa. É no banquete que o corpo se livra da piedade e do temor divino, reiterando o jogo e a fantasia, onde o vitorioso (Ponti) absorve o vencido e o renova. Nesta alegria da absorção do alimento o homem encontra-se com o mundo, se mistura a ele. No banquete, escreveu Bakhtin, "o corpo escapa as suas fronteiras, ele engole, devora, despedaça o mundo, fá-lo entrar dentro de si, enrique-se e cresce as suas custas", ele é o lugar deste encontro maior entre o homem e o mundo onde "o homem degusta o mundo, sente o gosto do mundo, o introduz em seu corpo, faz dele uma parte de si." ${ }^{219}$ Engolindo-o e sendo engolido por ele, a fronteira entre homem e o mundo, no banquete popular, aparece de forma a ser favorável ao primeiro, como se este triunfasse sobre o mundo.

Em síntese: o grotesco se caracteriza por um ultrapassamento das fronteiras entre dois corpos ou entre o corpo e o mundo - percebemos então, voltando a nossa discussão sobre o

218 Interessante lembrar que Pierrot le Fou também traz entre seus personagens um anão (assim como O Bandido da Luz Vermelha) e que o próprio Velásquez era considerado um pintor de figuras estranhas e bizarras: anões, aleijões, deformados... Essas figuras ressaltam, certamente, um gosto pelas zonas limites da composição e da representação do belo.

219 BAKHTIN. A Cultura Popular na Idade Média e no Renascimento: o contexto de François Rabelais - p. 245. 
“entre-as-coisas" (as fissuras, as fronteiras), a razão de Agrippino apelar tanto para um repertório grotesco. Em Hitler III ${ }^{o}$ Mundo, vemos o tempo todo esse corpo grotesco, hiperbólico, cujas partes parecem ter vidas independentes (há inclusive um pênis gigante que aparece em duas cenas do filme: na reunião do grupo subversivo em volta de um galinheiro; e na escadaria que leva aos porões da tortura, na cena em que Hitler visita “os infernos"), cujo ventre e o sexo, principalmente, estão sujeitos a todo tipo de excrescência e violência (durante a cena de tortura nos "porões", há uma tomada de um pênis sendo esticado e vilipendiado, assim como tendo seus pêlos pubianos arrancados). O grotesco do filme de Agrippino nos revela justamente esse interesse pelos limites do corpo, pelas saídas e entradas, por aquilo que o faz atravessar suas fronteiras com o mundo, daí seu apelo a imagens da genitália, dos mamilos e das nádegas. Essa fronteira é igualmente destacada por uma grande galeria de criaturas escatológicas: uma visita a um banheiro (suntuoso) de um posto de gasolina nos mostra $O$ Coisa bem no meio de uma bela mijada (e quem nunca se perguntou o que guardaria o homem de pedra dentro daquela sunguinha?); na cena da tortura subterrânea, os soldados fardados se mostram como um misto de homens e macacos; o próprio homem de classe média tem características bestiais (orelhas e boca despropositalmente grandes), para não falar em Hitler e no agente americano gordo e peludo que aparece o filme todo com um tapa-olhos.

Também encontramos em Hitler essa dimensão do corpo como perpétua renovação, como expressão cósmica e universal, como veio inalienável da morte e da concepção, típica do grotesco. Daí uma predileção pela união dos corpos a natureza: numa última cena, onírica, antes de ser diplomado como membro da organização, vemos o homem torturado correndo por um descampado. Um plano aberto ressalta a perspectiva mais em sua dimensão ótica que dramática - aos poucos a figura vai se aproximando. Ele então despenca de um barranco, aos trancos, até alcançar uma outra figura, feminina, que o espera, nua, sobre um colchão no alto de um monte. Em over, ouvimos a voz da moça discorrendo sobre o encontro de dois universos e sobre o momento em que seria possível saltar de um para outro. A união dos corpos, que de início é cinicamente carnal, com tombos e patuscadas (o homem insiste em apertar os mamilos desnudos da moça), se completa num 
plano distante, aberto, em contraluz, onde vemos apenas a silhueta dos amantes se imiscuindo a paisagem. Por fim, estes deixam o alto do monte e se dirigem, juntos, a represa onde seus corpos se perdem na água. Esse acontecimento é uma espécie de promessa do absoluto, do corpo grotesco como que se diluindo nos fenômenos naturais: na montanha, na luz, na água, enfim, nos cosmos; mas logo em seguida, num plano único, vemos novamente o corpo torturado do homem se debatendo violentamente na imagem - há sempre a ameaça de retorno ao complexo do corpo aprisionado pelo ente. ${ }^{220}$ Quando mais a frente, a voz da moça retornar a banda sonora, falando sobre espaçonaves e viagens siderais, veremos planos desencontrados de Hitler, do americano de tapa-olhos, e finalmente de um velório (que segundo Bodansky era um velório real, ou seja, trata-se, de fato, da imagem de um morto) que anuncia uma última sequência: num quarto pobre, vemos o homem (da tortura) sem camisa, sentado numa cama, depois, num corte na imagem que não altera nem seu eixo nem seu espaço, vemos um velho de magras carnes sentado na mesma cama (no mesmo lugar do homem); por fim a moça, no auge da beleza física, igualmente desnuda (também sentada na cama). Daí o filme se encaminha para seu desfecho: o rito está completo.

Diante da violência temporal frente aos corpos: seja ela do tempo, que fenece toda beleza, seja das ditaduras autoritárias, que fenecem o próprio tempo, só resta ao corpo renovar-se como um acontecimento para as gerações futuras. O corpo que interessa ao filme, portanto, não é o corpo individual, mas é esta cadeia infinita onde um corpo sempre nasce da morte de outro mais velho - o corpo grotesco é o corpo que ignora a superfície que o limita, ele é o corpo que se despeja, que se dejeta, que se transcende em sua própria imanência. Conforme Bakhtin: "o corpo grotesco é um corpo em movimento. Ele jamais está pronto nem acabado; está sempre em estado de construção, de criação, e ele mesmo constrói outro corpo; além disso, esse corpo absorve o mundo e é absorvido por ele." 221 A

$220 \mathrm{O}$ interessante é que neste plano quem propõe o confinamento é justamente o quadro. Vemos o corpo do ator se debatendo nas laterais do enquadramento como se este reiterasse a violência da prisão (e da imagem, que é sempre uma primeira violência). Logo em seguida, em outro plano, a câmera desprende-se de sua disciplina a passa a traçar movimentos circulares, a girar de cabeça para baixo, em movimento constante (ela está, igualmente, dentro de um carro em movimento), mas sem perder o eixo da imagem (que traz ao fundo os arranha-céus da cidade) - o dispositivo aspira ao delírio da representação, mas sem perder a ternura; a dimensão paramétrica da mise en scene não significa um abandono do rigor e da técnica, pelo contrário, significa a necessidade da criação de um novo olhar mais apurado sobre as coisas.

221 BAKHTIN. Opus Cit-p. 277. 
luta do corpo que desponta no filme de Agrippino é muito maior que aquela contra as castrações impostas pelo seu tempo histórico: os ditadores e as ditaduras passam (Hitler é morto pelo Samurai; o Samurai é morto pelo Agente Americano...), o que permanece de modo muito mais durável é esse cânone secular que retrata o corpo como uma experiência acabada, delimitada, fechada, sem mistura, expressiva, sujeita e individual. É contra a representação, humanista, burguesa, dos corpos e espíritos, que se levanta todo a contracultura - e a arte-soma do grupo sonda é, inegavelmente, parte importante dela.

Aqui, uma questão histórica desponta: o corpo grotesco, conforme descrito por Bakhtin, representa uma aspiração ao triunfo do homem sobre o mundo (ou pelo menos uma consubstanciação de ambos), só que isso se dá na cultura popular da tradição, será que o mesmo sentido ocorre na época dos mass media e da cultura pop de consumo ilimitado? O que Agrippino nos mostra, especialmente no acontecimento da TV, é que o grotesco num universo em que as imagens ocuparam todos os espaços simbólicos da vida, torna-se ele próprio um motivo de exploração espetacular, confundindo-se com o chamado "mundo cão" das grandes metrópoles - prato predileto de todo tipo de tablóide e pulp show. Por outro lado, Hitler $I I I^{\circ}$ Mundo vai também explorar uma ambiguidade resultante dessa exploração espetacular, uma ambiguidade de grande força imaginativa.

A última imagem de Hitler $I I I^{\circ}$ Mundo nos mostra o samurai (Jô Soares) em frente a um aparelho televisor. Seu rosto, colado a tela da TV, esbraveja e ralha, reagindo as imagens que hora despontam na tela, hora somem, como se o sinal fosse perdido. Ele então arranha e bate na tela com as mãos (e com uma espada) como se quisesse apanhar ou devorar as figuras que vez ou outra aparecem no monitor. Como um pólo negativo desse aparelho, o samurai é o próprio Real (embora ele próprio, sabemos, não passe de uma figura do universo dos comics). Este Real por sua vez, por estar tão perto, deforma as imagens da televisão como faria um imã. Descobrimos que o samurai é o real (ou o que nos restou dele) na medida em que podemos considerar que num mundo totalmente tomado pelas imagens, a ação primária do real é não aparecer, assim, o próprio real só pode tomar uma forma estranha, monstruosa, como uma espécie de imagem deformada de si mesmo. 
Desse modo, a proximidade do rosto do samurai ao monitor de televisão constitui uma interferência mútua: o pavor entra na imagem (televisiva) e a desmancha, assim como subitamente, no grito estúpido (e grotesco, com sua boca escancarada e gorda) do samurai, aquilo que resiste a simbolização (o horror) vem em direção ao sujeito como uma curvatura na representação - essa interferência, por sua vez, através da tela do cinema, chega ao próprio espectador do filme que é confrontado com um horror muito particular: o inominável de si. É no momento mesmo em que se espera que o sistema espetacular das representações tenha abrangido tudo aquilo que existe, o corpo inclusive, que as friç̧ões do sujeito com aquilo que poderíamos chamar de "realidade" ganham uma força inesperada (e historicamente nova) - num mundo subitamente tornado mercadoria (espetáculo) a abordagem do real pelo sujeito da representação é induzida por um tipo de náusea, de pavor que infiltra a imagem e que parece vislumbrá-la por dentro (e por fora).

Esse pavor difere da ordem clássica da representação do horror, pelo menos se consideramos que nessa ordem vislumbramos uma lógica mais plausível de separação da cópia e do original - o horror, ali, ganha um estatuto terapêutico e catártico (assim como a piedade) de (re)estruturação do sujeito. O fantasma, na obra poética, é aquilo que nos permite dizer "este é aquele" (imitação), sendo uma proeza da lógica o seu reconhecimento; daí a afirmação de Walton de que o medo que sentimos no cinema é um "quase medo", pois embora as reações fisiológicas sejam muito próximas, sabemos (analiticamente) que a ameaça não é real. ${ }^{222}$ Por outro lado, o horror em Hitler $I I I^{\circ}$ Mundo é da ordem visual contemporânea, ele é o horror da absorção da realidade no interior da representação, ele é essa perturbação (deformação) da virtualidade autônoma, é uma hesitação perante o Real - o momento em que a imagem olha de volta para o mundo. É um horror não acerca de uma anedota (de uma história) ou de um fato, mas acerca do próprio horror - como na concepção do crítico alemão Karl Bohrer sobre o terror: “o rosto dessa medusa não é algo que cause terror por si mesmo; antes, ela própria parece ver algo de aterrorizante (digamos, seu próprio destino mítico). ${ }^{, 223}$ Talvez o destino aterrorizante (e mítico) do samurai seja justamente o descobrir-se como 222 WALTON. Temores Fictícios. In: RAMOS (org.) Teoria Contemporânea de Cinema 1.

223 Citado em LEHMANN. Teatro Pós-Dramático - p. 238. 
algo além do horror representado: no instante final do plano, o samurai descola seu rosto do televisor e se volta, frontalmente, para a câmera. Ele então nos olha, só que esse olhar constitui um "não-ver", ele é desprovido de forma porque o objeto do olhar (e do horror) é um fora, é o espaço do irrepresentável. Ele então solta seu grito de horror (a montagem o interrompe no meio de um gesto, que talvez seja o da sua própria morte - um harakiri).

Essa boca escancarada (horrível) nos revela ainda uma última coisa: como uma figuração do grotesco, ela nos mostra que o lugar por excelência desse horror é o corpo, mas não o corpo iluminista, produto da disciplina e do conhecimento, mas o corpo como essa falta, esse ponto cego do Método. Na sua materialidade e desobediência, o corpo é aquilo que escapa ao teatro da civilização - sua monstruosidade é o desabrigo do sujeito. Por isso o sintoma é a sua verdadeira fala e nele se revela a potência (o alcance) deste grito: quanto maior for a extensão do imaginário, do mundo totalmente dominado pela cultura das imagens, maior será a ameaça do sintoma à estabilidade do sistema. O corpo grotesco na era da espetacularização hegemônica perfaz uma pergunta essencial, que é compartilhada pelo espectador do filme: o que, afinal de contas, aconteceu ao corpo?

Pois a dimensão performativa das ações e do olhar do filme nos oferece sempre a mesma resposta: ele está impregnado de pulsão de morte - e o samurai gordo talvez seja sua maior expressão. A primeira vez que o encontramos é logo após o acontecimento da TV, ainda na primeira metade do filme. Na banda sonora, cresce uma "peça" musical executada por um órgão - música sacra, cerimoniosa. Quando surgem as primeiras imagens do samurai perambulando pela favela, ouvimos sobrepondo-se ao órgão, sons de tambores. O samurai está de costas para a câmera, percorrendo uma viela por entre os casebres - subitamente, uma porção de crianças (quase todas negras) vem correndo na direção oposta, cruzando o seu caminho. Ele, no entanto, permanece em sua caminhada, impávido; num giro lento de $180^{\circ}$ a câmera o apanha de frente. Ela então nos revela o "mar de gente" que o segue, assim como nos mostra, agora do lado contrário, o espaço ocupado pela favela completando o campo de visão circunferencialmente. Nas palavras do próprio Bodansky, esse era o procedimento padrão nas filmagens externas com Agrippino: como não havia uma delimitação 
exata da área de intervenção dos atores, o espaço da ação tornava-se um "espaço total" - daí a sensação que temos de estar diante um registro documental: um documentário sobre a metáfora. O samurai então pára bem próximo da câmera, ele se despreguiça, parece tirar do peito um inseto, uma pulga. Ele está a vontade naquele lugar, parece inclusive pertencer a ele (a sensação que temos é que ele acabou de acordar). Essa "familiaridade" da figura entra em franco contraste com os demais rostos que aparecem na tela, nitidamente curiosos e intrigados com o tal acontecimento (com a filmagem que acontece diante dos seus olhos; com aquele ser bizarro desfilando na porta de suas casas). A câmera, no entanto, em nenhum momento parece se interessar por eles $^{224}$, na verdade, descobrimos seus rostos apenas em relação a estranheza da figura do samurai - a miséria assim, vista desse modo, sem transcendência retórica e como parte de uma apoteose circense, nos parece ainda mais insuportável.

Esse samurai nos é depois apresentado em retratos do cotidiano: ele corta o cabelo numa barbearia de esquina, toma saquê num restaurante da liberdade, enfim, ele é uma emanação das massas, vive no meio delas - na banda sonora, durante a cena no restaurante, ouvimos a canção Charles Anjo 45 de Jorge Ben, penso que não à toa: o samurai é uma espécie de herói populista, ele protege o povo para poder explorá-lo. Isso fica claro na segunda sequência do samurai na favela. Com uma bacia de verduras murchas ele alimenta a massa famélica que se diverte com aquela "gincana" para a câmera (a lógica televisiva). Essa massa, na sua maioria composta de jovens, é retirada de debaixo de um plástico preto e depois de alimentada como animais é conduzida para uma kombi, numa das cenas mais memoráveis e perturbadoras do filme. A medida em que a kombi vai se enchendo de gente (e a cena vai se tornando mais e mais insuportável), um homem toma notas num caderninho, como se contabilizasse o número de corpos para o abate. Do teto do veículo, a mesma anãzinha da TV espia tudo. O grotesco da cena impressiona em duas transmutações: se por um lado a máquina (a kombi) adquire uma feição humanamente monstruosa (como se fosse uma boca a devorar aquelas crianças), as pessoas adquirem uma feição objetal, são reduzidas a sua porção de coisa (de alimento). É um processo semelhante (embora sociologicamente mais perturbador) ao do personalizá-los; mas a ação performática dos "monstros” de Agrippino sempre acaba falando mais alto. 
acontecimento inicial na borracharia, onde o casal de classe média acaba sendo levado para a recauchutagem. É a arte no horizonte de um universo massificado de reificação:

\begin{abstract}
“Grande parte da ação, violenta ou não dos Happenings implica o uso da pessoa como um objeto material. É freqüente os executantes usarem sua própria pessoa de maneira violenta (eles pulam, caem, são erguidos do chão, perseguidos, jogados, empurrados, golpeados, lutam entre si); as vezes a pessoa é usada de uma forma mais lenta, mais sensual (acariciada, ameaçada, observada atentamente) por outras pessoas ou por ela própria." 225
\end{abstract}

Toda a pulsão de morte do samurai fica explícita nesse happening marginal, e não apenas por conta da figura (e da prática) sinistra do samurai. Na medida em que este acontecimento na favela, como um evento performativo, trabalha sobre os corpos como um objeto que lhe é estranho (como faz o pintor com suas telas), há uma certa recusa da ilusão teatral em favor da corporeidade do espaço físico (que inclui os corpos dos performers e, portanto, seu sofrimento, vemos, por exemplo, crianças chorando ao entrar na kombi) - é como se os corpos dos meninos da favela fossem petrificados (como a medusa que olha a si mesma no espelho e queda petrificada ante seu destino horrível) diante dos espectadores - incluindo aqueles que assistem o acontecimento in loco durante a filmagem, constituindo apenas corpos mudos e esquizóides, marchando rumo a dissolução maquinal do sujeito. Essa dimensão performática da cena está, assim, embebida de pulsão de morte justamente porque, nas palavras de Ferál, "la performance comme phénomene travaillé par la pulsion de mort" ${ }^{\prime 226}$, e ela o faz de modo deliberado para desmistificar o sujeito, daí seu interesse pelo corpo mutilado, reificado, desmembrado (assim como a massa é uma representação dilacerada do povo).

Comparemos, assim, essas cenas da favela em Hitler com aqueles tableaus do povo na praça em O Dragão da Maldade e o Santo Guerreiro. O que vemos neste último é que a disposição dos corpos entre si revela um comportamento coral, revelando tensões ou reafirmando posições individuais dentro do coletivo, daí a grande força alegórica de seus quadros e de seus movimentos coreografados. Pois se Glauber se interessa ainda pela expressão do coro (mesmo 
realizando uma coreografia fora de centro, artificiosa, apontando já para a dissolução de uma mitologia popular e para os impasses irreconciliáveis de tal concepção populista), Agrippino já flerta com a noção de "coralidade", conforme a expressão de Sarrazac: um contexto de falas estilhaçadas, um coletivo de vozes dissonantes onde o coro não é mais possível (e, portanto, onde a noção de um “povo" se dispersa) - esse é um qualificativo essencial das estéticas híbridas, ou seja, da própria idéia de uma arte-soma.

É desse modo, igualmente, que a câmera no meio da multidão favelada em Hitler, embora possua um olhar privilegiado sobre a ação, joga constantemente com a possibilidade de constituir-se simplesmente como um olhar entre outros. Isso porque se aquilo que define o teatro é a relação (e a separação) manifesta dos atores com os espectadores, na performance, por excelência, a ação se instala nas variações entre os espaços físicos e imaginários, jamais se decidindo integralmente por um ou outro. Percebemos dessa forma que a impressão documental da filmagem de Hitler, emprestada tecnicamente do cinema-verité, constitui-se na verdade como uma performance do olhar a respeito dessa possibilidade, dessa asserção pressuposta ${ }^{227}$ do cinema como um registro documental. Assim, a "coralidade" das massas em Hitler vem impregnada de uma certa recusa da noção de "teatralidade", noção esta muito presente no filme de Glauber na medida em que esta teatralidade parece implicar imediatamente numa noção de alteridade ${ }^{228}$ (fundamental para a construção de sentido de um povo, por exemplo). Essa noção de alteridade é igualmente fundamental para grande parte do melhor cinema documentário já produzido, que por isso mesmo tem muito de teatral.

Pensemos num filme como Moi, une noir de Jean Rouch que trabalha explicitamente com essa noção de teatralidade, de ficcionalização do Eu. Ali, dois jovens imigrantes contam-nos suas vidas como estrangeiros sub-empregados em Treichville na Costa do Marfim (um dos então novos grandes centros urbanos do continente africano) através de uma estratégia engenhosa: ambos são apresentados com os nomes de famosos atores do cinema, livremente escolhidos por eles 227 CARROLL. Ficção, não-ficção e o cinema da asserção pressuposta: uma análise conceitual in: Teoria Contemporânea do Cinema 2.

$228 \mathrm{O}$ ator teatral demanda sempre um outro, trabalha sempre em relação a alteridade de um personagem. Devo a noção de que a teatralidade implica numa idéia de alteridade igualmente a Josette Ferál (ver nota 229). 
(Edward G. Robinson e Eddie Constantine); assim como escolheram seus atores, eles igualmente definem seus papéis no filme, seus personagens: (Edward G.) Sugar Ray Robinson, campeão de boxe, e (Constantine) Lemy Caution, agente secreto do governo americano. Na medida, no entanto, em que a "trama" do filme vai se desenvolvendo a partir das experiências cotidianas dos dois rapazes, vamos descobrindo suas personas para além dos personagens escolhidos. Como em "A Ratoeira”, a peça dentro da peça em Hamlet, só a encenação de si mesmo como (e para) um outro é capaz de revelar, com toda a sua fúria, a tragédia de nossa personalidade (fazendo vir à tona a perfídia). O processo culmina com a prisão de um dos dois rapazes (que parece ter levado seu papel a dimensões extravagantes) e com o famoso depoimento final de "Edward G. Robinson" em que ele nos revela finalmente não apenas seu nome, mas seu número de série como ex-fuzileiro naval a serviço da França na Indochina (reencontrando assim seu "lugar" na história). Ao longo de todo o filme, é através desse "jogo de cena" que os protagonistas do filme alcançam uma identidade (que só pode ser a deles próprios); é igualmente acompanhando esse processo que nós, os espectadores, podemos encontrar nesses outros, além deles mesmos, aquilo que poderíamos chamar de "nós". A dimensão etnológica da ficção não está para Rouch na busca de uma verdade que irrompa subitamente no cinema, mas só pode ser a verdade do cinema: a montagem do filme assemelha-se ao processo de edificação dos sujeitos (antropológicos) da narrativa (da história) - suas identidades são desfraldadas através de um processo de reconhecimento que Aristóteles já havia descrito como prototípico da obra poética (embora não fique claro na obra do grande filósofo se esse mesmo processo se dava igualmente no interior do espectador; mas o certo é que a lógica do reconhecimento, por si só, nos fornece, pelo menos, a "ilusão" de um sujeito.)

Pois é justamente esse processo que é constantemente interrompido em Hitler e isso se deve a dimensão performática dos acontecimentos. A performance sempre repõe o real como uma falta, uma ausência. Ela nega a alteridade porque visa apenas, em última análise, não uma transformação (a realidade transformada artisticamente por meios de materiais ou gestos, como no teatro), mas uma auto-transformação (o momento único; a ação que afeta o próprio corpo tornado 
objeto $^{229}$. Por outro lado, se em Hitler $I I I^{o}$ Mundo os acontecimentos nos colocam sempre diante dessa materialidade irredutível da ação, a montagem desses acontecimentos e sua exibição pelo dispositivo fílmico recolocam por princípio para o espectador o teatro (a transformação) dessas imagens (performances). Daí minha ideia, esboçada aqui, de que a arte-soma de Hitler III ${ }^{\circ}$ Mundo consegue inter-relacionar as performances com a teatralidade desse espetáculo de acontecimentos.

Para tanto, uma ponderação importante: é claro que não podemos afirmar integralmente a "performance como arte" no filme de Agrippino, mesmo porque ela ainda nem mesmo existia como uma prática reconhecida e institucionalizada, mas principalmente, e isso é o mais importante, porque a objetividade antiteatral da performance é relativizada no filme de Agrippino pela presença irrevogável tanto de uma hiperbolização da encenação quanto do próprio dispositivo cinematográfico, que parece sempre implicar num espectador ideal, herança do teatro ${ }^{230}$ - um espectador, por exemplo, que nunca é reduzido a uma dimensão de mero significante (como acontece com frequência nas performances). O que eu estou propondo aqui é que Hitler $I I I^{\circ}$ Mundo, como esta arte-soma, nasce justamente dessa fricção constante entre a performatividade dos acontecimentos (sua atuação indecidível entre o espaço real e o imaginário) com a teatralidade própria a fatura do filme (a montagem desses acontecimentos; as características de recepção e produção do dispositivo). Nele, se a noção de alteridade é constantemente vilipendiada (os atores, por exemplo, não “interpretam” outros, apenas compõem figuras do horror), resta ao espectador não a identificação, mas um outro processo que é lhe oferecido pela "encenação" do filme: o descobrir-se como uma fronteira onde o corpo é seu próprio devir, um corpo que só pode nascer desse "entre-as-coisas" (da montagem, dos objetos, do olhar). Seu evangelho tem outro vaticínio: no início, era o horror.

Esse horror é também um horror do real, como nos mostra o acontecimento com $O$ Coisa no alto de um prédio no centro de São Paulo. Como uma intervenção urbana, esperavase que a cena provocasse reações nas pessoas que passavam pelo local, o problema é ninguém

229 Para um esclarecimento mais amplo da noção de auto-transformação como própria a performance ver o capítulo (4) intitulado Performance do livro de Hans-Thies Lehmann O Teatro Pós-Dramático.

230 Conforme notou Ismail Xavier, a posição da câmera materializa a ideia do vértice da representação, "aquele ponto de observação para o qual a cena se volta". XAVIER. O Lugar do Crime. In: O Olhar e a Cena - p. 66. 
conseguia enxergar o homem de pedra no topo do edifício, o que obrigou a equipe de filmagem a alardear com gritos e com braços apontados para o alto a presença da "performance" em andamento. Está registrado no filme, a equipe literalmente criou, no momento da filmagem, o espaço da ação em cena aberta. Mais significativo é que com tal alarde a polícia não tardou em aparecer (lembremos que estamos em 1968), só que ao invés de intervir nas filmagens, os policiais acabaram topando uma proposta de Agrippino e entram no filme! Eles estão lá, na sequência que mostra $O$ Coisa sendo preso (alguns deles inclusive tomam uns belos bofetões do monstro); depois de dominado, o homem de pedra é conduzido para o camburão, com uma multidão de gente assistindo a ação. Esse caráter performático de intervenção no espaço do cotidiano é tão forte no filme que vale aqui um depoimento de Bodansky: nos extras ao DVD de Hitler ele confessa que, ao realizar do interior do camburão o plano onde o $O$ Coisa é preso, quando os guardas fecharam a porta, ele não sabia dizer se era apenas parte da encenação ou se eles (da equipe) estavam, de fato, presos. Algo desse "nó na garganta", dessa porção indecidível entre o real e o ficcional, impregna todo o filme.

Por fim, toda a dimensão desse horror primordial (e real) fica explícita mesmo é no acontecimento final do samurai na favela. Perseguido pelo agente americano (depois de ter matado Hitler com golpes de espada quando este tomava banho), o samurai é metralhado e morre. Nesta sequencia final, a câmera nos mostra o samurai morto sendo carregado pelas crianças da favela num carrinho de mão. Elas se amontoam e se acotovelam para empunhar o carrinho e aparecer no filme. Seu corpo é então recoberto com jornais (as crianças parecem obedecer a uma voz de comando em off), a maneira das mortes violentas retratadas cotidianamente pelos jornais sensacionalistas. Num discreto movimento de câmera, vemos a movimentação dos carros na marginal tietê, o samurai morto está agora prostrado bem ao lado da pista, junto a uma pequena multidão de favelados. Subitamente, aparece no quadro um guarda da força pública; ele orienta o tráfego, faz os carros circularem (um caminhão comercial enche a tela - é o Brasil do futuro, o Brasil Grande das rodovias). Essa é uma imagem muito significativa: diante do samurai morto, a cidade não pode parar, só que o espanto não surge daí, mas sim do fato de que os carros sigam em frente em sua rota (e de que o guarda cumpra 
suas funções cívicas) mesmo diante desse horror enorme, inominável, que nada mais é do que a miséria imensa daquelas pessoas, exibida todos os dias ali nas margens da mais importante via expressa da cidade! Essa é uma imagem ainda mais "sintomática" se pensarmos que naquele momento político da nação brasileira o milagre econômico se anunciava, e a ampliação e pavimentação daquela marginal seria símbolo da vocação paulistana ao progresso, resultando na completa desapropriação e abandono daquelas famílias que aparecem ali, então, já como uma ruína, uma ruína do futuro, se considerarmos que quem olha, ali, são na sua maioria crianças.

Diante dessa evidência, a câmera de Bodansky só pode realizar um único movimento. Ela deixa o corpo do samurai coberto de jornais e por um breve instante se detém nos rostos daquelas crianças, para depois, numa espécie de travelling para trás, se afastar deles, mostrando-os agora cada vez mais a distância, como uma massa amorfa amontoada às margens da via expressa, tendo a sua frente o corpo morto do samurai. Difícil pensar num movimento que mostre tão eloquentemente a fratura exposta no projeto do cinema novo ${ }^{231}$ : nesse travelling para trás, feito com câmera na mão, o povo é abandonado e sua fome torna-se apenas um borrão silencioso na imagem (vale lembrar também que a referência ao cinema novo aparece igualmente na banda sonora, onde os cantos de candomblé, tão presentes nos filmes de Glauber do período, irrompem volta e meia no áudio, mas sempre acabam "dessintonizados” ou sobrepostos por ruídos ou arranjos sinfônicos). Qualquer possibilidade intelectual de “ir até o povo", tão presente nas discussões até Março de 1964 (e mesmo ainda um bom tempo depois) parece desabar às margens do Tietê (e do progresso). Esse planos na favela em Hitler parecerem-me todos filhos bastardos daqueles planos de multidão em Terra em Transe, e mais especialmente ainda daquele gesto de Paulo Martins tapando a boca do "povo" (e lembremos que Agrippino fora uma das primeiras pessoas a ver o filme ainda nos copiões), um gesto que desponta na tela com a força de um gestus histórico (e transcendental): com ele a identificação entre o público do cinema novo e suas imagens (do povo, dos intelectuais) é distanciada

231 Esse "travelling para trás" me parece livremente inspirado na dimensão coreográfica presente em Terra em Transe, filme chave para entender toda essa fratura no projeto "nacional-popular". Sobre a coreografia e os movimentos de câmera no filme de Glauber ver: MACHADO Jr. Estudo sobre a Organização do Espaço em Terra em Transe. 
(para usar o vernáculo brechtiano) em nome de uma contradição fundamental: Afinal, quem é o povo?

E quem pode dizê-lo? ${ }^{232} \mathrm{O}$ divórcio do poeta-intelectual de suas categorias ontológicas de pensamento marca assim a ruptura de um paradigma de intervenção e a abertura para novas veredas. ${ }^{233} \mathrm{~A}$ imagem do povo famélico em Hitler libera a dimensão mórbida da própria imagem, seu poder assassino, a medida em que esta se julga agora incapaz de oferecer um significado para o mundo. Nela, um rosto anseia tornar-se imagem não mais para durar, mas para melhor desaparecer. ${ }^{234}$

Como escreveu o crítico José Carlos Avellar, esta gesticulação abstrata de imagens e sons que se justapõe numa estrutura reiterativa da montagem, típica de um filme como Hitler, "coloca a platéia no meio de uma espécie de cerimônia religiosa, de um ritual onde as pessoas rezam, baixinho, para si mesmas, sua fé na impotência”. ${ }^{235}$ Esse Rito que celebra a própria impossibilidade da ação seria um traço comum a todos os filmes do Cinema Marginal. Nas palavras de Cláudio da Costa:

\footnotetext{
"na imagem-inação do Cinema Marginal, ninguém age. Só existe o próprio ato da imagem, esse deslizar-se de uma em outra. É o ato especular que a própria imagem pratica, o duplicar-se , o ver-se em seu duplo. Não há, entretanto, uma coisa ou um alguém determinado que seja duplicado. A partir do momento que alguma coisa se duplica na imagem,
}

232 Lembremos que, logo em seguida ao tal gesto, o personagem de Flávio Migliacco vai declarar que Severino, o operário (cuja fala fora cerceada), não era o povo, mas o verdadeiro povo era ele, um miserável (ou seria um extremista?)

233 Sempre achei muito interessante que Caetano Veloso, em seu discurso famoso (e enfurecido) contra as vaias da platéia durante a apresentação de É Proibido Proibir no Festival da Canção de 1968, encarnasse uma espécie de êmulo de Paulo Martins. Ele aproveita a contradição aberta no seio do debate artístico-intelectual pelo filme de Galuber e, suspendendo a canção, incita o público, em grande parte composto de universitários: "É essa a juventude que diz que quer tomar o poder? Mas que juventude é essa (...) Vocês não estão entendendo nada!" Não é à toa, portanto, que Caetano afirme com todas as letras em Verdade Tropical que "Terra em Transe" foi o filme que lhe forneceu todas as dicas.

234 Jean Baudrillard já percebera algo deste tipo no artigo L'Horizon de la disparition in: BAUDRILLARD. Le Crime Parfait (p. 61-72).

235 AVELLAR. Cinema Dilacerado-p. 91. 
Decerto que Hitler III ${ }^{o}$ Mundo partilha muito dessa atmosfera de desmoronamento das ilusões (e das representações), mas é preciso apenas lembrar que essa incapacidade ou impossibilidade da ação que parece desabilitar-se "da necessidade efetiva de uma intervenção da obra na realidade concreta de maneira a transformá-la"237 se faz em nome de um nova dimensão da praxis: o corpo redescoberto. O que pretende a arte-soma de Agrippino (e Maria Esther) é transformar essa fé na impotência numa crença da carne - crer no mundo transformado é simplesmente crer no corpo.

A própria Maria Esther encarna em Hitler essa crença. Como uma personagem obscura denominada Madame Divac, encontramo-la no filme feito uma prisioneira de Hitler que acaba "executada" publicamente numa cerimônia sinistra. Toda a sequência de sua execução constitui na verdade um pretexto para uma espécie de acontecimento coreográfico cujo epicentro é a figura desnuda de Maria Esther preparada para o martírio. Eis um "rito" de expiação (e nascimento) da carne, encenado pelo cinema como um happening espetacular: nas arquibancadas de um estádio deserto, uns poucos espectadores são filmados numa espécie de transe hipnótico e fantasmagórico (estes espectadores não são outros senão os "apóstolos" da cena do barco) a partir de um plano aberto, panorâmico, com franco sabor geometrizante (uma citação de esguelha as bruxarias épicas de Leni Reiefenstahl); num segundo plano, geral, já no "gramado" do campo, vemos o carrasco retirando o manto negro que recobria o corpo de Maria Esther (ao seu redor estão de um lado um arauto medieval e do outro o próprio Hitler); num terceiro plano, médio, o corpo desnudo de Maria Esther ocupa toda a dimensão do quadro, ela então é recoberta com um plástico transparente; este plano é repetido pela montagem (na banda sonora, ouvimos Charles Anjo 45). A escala dos planos, do panorâmico ao aproximado, acompanha o transe da carne: num primeiro momento os corpos, vistos de longe, tornam-se traços lânguidos se debatendo na tela, eles estão em convulsão, experimentam o espaço (da 
tela) como se aspirassem a condição de massa amorfa - são ornamentos (do quadro); no último, por sua vez, o contraste é nítido: a serenidade desnuda de Maria Esther enche o quadro, toma-o de assalto, é tão pregnante que obriga a montagem a repetir o único gesto realizado pelo corpo (ela leva as mãos aos seios e abaixa a cabeça) - o plástico transparente que vem recobri-lo dá-lhe ao mesmo tempo o vatício da morte e a certeza da ressurreição: somos feitos da mesma matéria que os objetos.

A anunciação se completa num quinto plano: vemos sua figura transfigurada numa "virgem emplastificada" sendo conduzida, por entre um bosque, para o holocausto (os raios de sol refletidos no plástico transparente "estouram" a fotografia) - a sequência é interrompida por cenas do Samurai na barbearia - mais adiante, a montagem recupera o acontecimento da expiação: vemos finalmente Divac sendo executada sobre uma pedra (o machado desce-lhe até o pescoço; jogam-lhe tinta sobre o corpo - a cena é toda ela "teatral"); no entanto, no plano seguinte não é ela quem está morta ao lado do carrasco (será Jesus Cristo?), até que, por fim, vemos a conclusão do cerimonial: Divac, de negro, com o plástico sobre o rosto, sai de cena sorridente, abraçada com Hitler. A impostura da anedota é própria do bom humor dos happenings, especialmente em sua versão nacional - mas o que interessa mesmo aqui é essa materialidade dos objetos representados na cena. Nesta dança das formas, as figuras impõe-se sobre os significados e os corpos aspiram ao movimento dos afetos - o cinema como uma coreografia de ritos.

Desde pelo menos Jules-Marey e seu método gráfico de representação do movimento através da cronofotografia de placa fixa, já se aventava a idéia de uma arte cinética capaz de desvelar profundamente o movimento próprio de todas as coisas (através da reconstituição desse movimento); nesse sentido, o cinema, justamente por sua "cineplasticidade" ${ }^{238}$, teria uma genealogia em comum com a música e com a dança, com as quais partilharia as mesmas leis e funções. Grande parte do debate sobre o específico filmíco, por exemplo, se deu no afã de definir, nesse sentido, qual contribuição única cabia ao cinema para a constituição de um espaço e de um tempo dentro de uma teoria das artes que tinha o ritmo como preceito fundamental. Assim se deram desde as sinfonias das 
cidades (as teorias de Ruttmann) e dos balé mecânicos, até as experiências do professor Kulechov que, como muitos russos de seu tempo oriundos dos palcos, acreditava que a essência do teatro repousava na disciplina rítmica do corpo do ator (à época, a ginástica rítimica do ator de Delsarte e o método eurrítmico de aprendizagem musical de Delcroze faziam muito sucesso como modelo para o estabelecimento de relações íntimas entre as ações físicas e os desejos) e que assim talvez fosse possível transmiti-la, com ganhos de precisão, para a montagem dos filmes, o que resultou numa série de experimentos fílmicos com atores e bailarinos do qual conhecemos, geralmente, apenas o famigerado "efeito Kulechov" - nele, é a técnica que confere ao ator a intensidade expressiva (rítmíca) desejada.

Talvez o primeiro e até hoje marcante fênomeno cinematográfico que vislumbrou uma união mística entre dança, música e cinema tenha sido as chamadas "danças serpentinas", nomes pelas quais ficaram conhecidas as criações da bailarina Loie Fouller (1862-1928) que se tornaram muito populares ainda nos anos finais do século XIX através de pequenos filmes realizados por imitadoras para Edison Co. ${ }^{239}$ Neles, refletidas pelo movimento sinuoso do imenso tecido que compunha o vestido da bailarina, a luminosa energia criava uma sensação de irrealidade, destituindo o corpo de qualquer presença, substituído-o pela ilusão de fluidez energética de um outro corpo, agora feito luz, linha abstrata ondulante capaz de evocar no mesmo momento o êxtase de um ritual e a mais clássica das representações, a da linha ondulante como ideal de beleza de representação do movimento. Fuller teve certamente uma grande influência na vanguarda cinematográfica francesa, basta pensarmos, por exemplo, no "cinema puro" (a forma desprovida de todo sentido demasiado humano) preconizado por Germaine Dullac num filme como Étude Cinegraphique sur une arabesque (1928).

Pois na década de sessenta, as relações do cinema com a dança se dão através de uma redefinição da própria ideia de movimento. Agora não são mais os cineastas que vão atrás dos corpos luminosos das bailarinas para realizarem no écran suas sinfonias de luz e sombras, são os 
coreógrafos que vão se apropriar do cinema como uma redescoberta da intensidade dos gestos a que se acrescenta um questionamento da função ideológica do corpo e suas representações. É o momento das mulheres, de cineastas como a norte-americana Yvonne Rainer e suas performances para a câmera (por vezes, com apenas partes do corpo) ou da francesa Jackie Raynal que virou a "queridinha" da crítica de vanguarda parisiense ao despontar como parte dos experimentos do grupo Zanzibar no pós68 fazendo filmes performáticos e gestuais ${ }^{240}$; era, enfim, o momento de Maria Esther.

Sua presença em Hitler, embora discreta, é marcante - e um dos bons momentos onde podemos ver isso é no acontecimento da execução. Já na cômica reunião em que o Jurisprudente discute com Hitler o "caso" Madame Divac (ali descobrimos que paira sobre esta senhora a acusação de ter abusado fisicamente de um garoto de 11 anos!) sentimos a verve coreográfica de Maria Esther bem acima da mesa onde acontece o encontro, onde o Jurisprudente discute assuntos da maior retidão moral com Hitler, vemos uma fileira de pés que se movem o tempo todo no canto do quadro cortados na altura dos joelhos, esses objetos / fetiche se imiscuem na paisagem da cena dando-lhe a mesma força poética que esta só pode possuir nos sonhos. Igualmente na cena da execução - a presença corpórea de Maria Esther, desnuda, quase sem gesto, apenas protegendo seus seios e baixando a cabeça para que lhe cubram com o véu de plástico é de um estofo lírico e visual deslumbrante (reiterado pela montagem que faz questão de repetir o plano). Sua nudez ao mesmo tempo altiva e singela, aceitando o sacrifício da carne, mas rejeitando qualquer sentimento de culpa, é um desafogo do feminino num regime patriarcal e autoritário. Sua virgem plastificada, desfilando pelos bosques de símbolos do terceiro mundo é a nova imagem da ressurreição da carne. A busca dessa imagem se estenderá pelo cinema super-8 que Agrippino e Maria Esther realizarão ao longo dos anos 70: ali se dará o projeto de uma arte-soma menos como a reunião mística de todas as artes e mais como essa ressurreição no corpo (e da imagem).

O que se esboça já em alguns momentos de Hitler e o que se buscará em todos os experimentos em Super-8 da dupla Agrippino / Maria Esther dos anos 70, é algo da ordem de uma 
simbiose entre o movimento filmado e a imagem em movimento, uma assimilação da gestualidade da dança a uma expressão cinematográfica capaz de aproximar o olhar do cineasta ao corpo filmado, talvez amalgamando-os numa utopia de imagem-corpo - as informações não são transmitidas pelo corpo, mas transformadas em corpo; não se trata de dançar no lugar, mas de fazer dançar o lugar. Maya Deren havia tentado algo semelhante com seu Coreocine - nele, a câmera não deve pretender traçar os passos junto com os bailarinos, ela não é um embuste dos movimentos coreografados, ela não os mimetiza simplesmente; numa coreografia para a câmera, esta deve respirar junto com o bailarino - a imagem-corpo é uma imagem que respira. Maya Deren parece ter buscado essa respiração da câmera toda sua vida.

Por outras vias, já nos anos 70 alguns coreógrafos como o próprio Merce Cunningham vão se apropriar do vídeo como forma privilegiada de estudo cênico e coreográfico. O espaço bidimencional do objeto vídeo permite ao encenador uma melhor percepção sobre os corpos no espaço tridimencional (volume, figuração, espacialidade), além de proporcionar-lhe uma série de recursos novos (sobreposições, reenquadramentos, montagens), todos brindando-lhe com novas formas de temporalidade. O vídeo transporta os corpos dos bailarinos para o território da imagem e estas se duplicam como os corpos ao ritmo da música. Na montagem de tempo e espaço próprios a imagem, nasce o videasta como coreógrafo - é o caso de um nome como Charles Atlas, parceiro de Cunningham em projetos como Changing Steps ou Blue Studio. Diante dessas considerações, uma hipótese me aparece.

Pela própria particularidade do vídeo, por sua condição menos de medium e mais de estado (da imagem), e principalmente pelo modo como esta condição foi explorada no trabalho das vanguardas setentistas (na criação de máquinas de fazer imagens), talvez ele não sirva tão diretamente aos preceitos simbióticos nem do coreocine de Deren, nem da arte-soma de Agrippino e Maria Esther. Há nessas duas experiências uma fome pela possessão das (e pelas) imagens fortemente inspirada na sacralidade das cerimônias tribais, algo que só o cinema como esta invocação de sombras mágicas, como esta redescoberta fenomenológica dos objetos, como este extraordinário do ordinário 
poderia realizar, especialmente se imaginarmos certo imbricamento dos corpos em diáfanos movimentos luminosos. O vídeo, me parece, interessa aos coreógrafos contemporâneos justamente por, como imagem eletrônica, colocar-se entre as ordens da arte e da comunicação, ocupando assim “uma posição difícil, instável, ambígua: ele é a um só tempo objeto e processo, imagem-obra e meio de transmissão, nobre e ignóbil, privado e público. Ao mesmo tempo pintura e televisão". ${ }^{241} \mathrm{O}$ vídeo é a imagem para além do seu meio, portanto, por definição, uma experiência sem corpo - a “artesoma", por sua vez, embora desmaterialize o corpo e reze baixinho por sua expiação, parece sempre recolocá-lo no horizonte como uma aspiração. O paradoxo do vídeo em relação a poética de Agrippino é que justamente ao realizar de modo quase definitivo a imaterialidade das imagens através de processos contínuos de sobreimpressão e incrustação, o vídeo fracassa como "arte-soma" pois nele as artes não mais se "somam" (se imbricam), mas se "multiplicam" (em camadas sucessivas) - nele cada imagem tornar-se um ensaio sobre si mesma, sobre sua existência como imagem.

Não estou afirmando aqui que o vídeo por definição seja incompatível com o tipo de experiência estética aqui descrita, o próprio Agrippino teve contado com video-artistas nos anos $80^{242}$ com alguns resultados interessantes, apenas estou sugerindo que não foi por mero acaso que o Super-8, a mais pessoal e tátil das bitolas, tenha se tornado o lugar privilegiado da utopia existencial de Agrippino e Maria Esther depois do Rito - ele significou, após esta viagem ao limite da representação que foi Hitler $I I I^{\circ}$ Mundo, uma volta ao corpo da imagem sensível, um retorno à luz, ao calor da cor, do movimento, muito afinado a certos ideais hippies então abraçados por seus realizadores. Menos do que um precursor dos artistas multimídia contemporâneos, como costuma hoje ser chamado pelos seus apologistas, Agrippino me parece um dos últimos feiticeiros modernos, pois se buscou livrar-se da pureza dos meios, foi para recolocar a arte no horizonte da vida. Ele buscou levar a experiência estética até o abismo da sua crueldade e como todo grande feiticeiro, acabou tragado por seus feitiços: quando a arte-soma se realiza, ela descobre imediatamente o seu limite, a

241 DUBOIS. Por uma Estética do Vídeo. In: Cinema, Video, Godard - p. 74.

242 Em 1988, Lucila Meirelles realizou um documentário poético intitulado Sinfonia Panamérica, trabalho este que aproxima a obra de Agrippino de certas questões próprias a estética do vídeo. 
sua finitude, o seu fracasso.

Permaneçamos, por fim, ainda um instante em Hitler, filmado no olho do furacão em 1968. Naquele momento, esta nova ressurreição da carne através da sua própria imanência visível ainda se dá como um documentário sobre a crucificação - todo o filme é uma espécie de via dolorosa pelo horror fascinante das imagens, que terá o seu "terceiro dia" nessa "assunção" cênica que será o Rito do Amor Selvagem. Assim, estruturam-se estas obras de arte-soma como o ponto máximo da vanguarda, o verbo desencarnado e reencarnado. Depois, para além deste rito de amor e barbárie, restará apenas a matéria viva da eternidade, a dança das formas, vista através das intactas retinas de uma Canon 814. 
Conclusão: Além Do Rito 


\section{$* * * * *$}

"Eu morri no Rito e renasci lá...", ${ }^{243}$ assim Maria Esther definiu sua estadia na África nos idos da década de 70. Tal viagem de redescoberta do mundo torna-se o paradigma de uma aesthesis reencontrada - a arte deve sacrificar-se para dar origem a um novo tipo de comunicação dos afetos. Antes, pois, seria preciso matar o verbo para renascer feito um corpo puro, muito longe de Deus, mas perto do coração selvagem das coisas: eis o que se propõe com o Rito - a poesia deveria se apropriar do espaço e se afirmar neste domínio que não pertence as palavras. Daí a supremacia absoluta em cena da visualidade dos objetos, dos cenários, dos movimentos, assim como a consequente destituição da humanidade dos atores, tornados simples formas a conclamar uma celebração à vida. O rito é este cerimonial de passagem rumo a uma outra dimensão da experiência.

Tal celebração acontece em Dezembro de 1969, simbolicamente dando encerramento ao II Festival Paulista de Dança (e a década dos sonhos), o mesmo evento que no ano anterior havia sido "inaugurado" pela montagem do espetáculo Tarzan $I I^{\circ}$ Mundo - é como se o Sonda já anunciasse, no mesmo local de seu nascimento, o fim de seu breve ciclo de experimentos: para além do Rito não haverá mais teatro, mas apenas o ato em sua nervura. Assim, em 7 de Janeiro de 1970 o Rito do Amor Selvagem faz sua estréia em temporada no teatro São Pedro, deixando o crítico desamparado em suas observações:

\footnotetext{
“...embora definida no programa como ballet, não pode ser classificada segundo nenhum dos gêneros ou artes conhecidas. Longe de ser ballet, ela tampouco é teatro declamado ou musical, nem é circo ou show, nem happening e nem pantomima, embora apresente elementos de todas estas formas artísticas ou extra-artísticas (...) em experimento tão novo, que faz mixagem de tantos gêneros e artes diversos, não há, por hora, critérios para criticar. ${ }^{244}$
}

243 STOCKLER. Entrevista ao CCSP - Citada em MADAZZIO. Opus Cit. - p. 120. 244 ROSENFELD. O Rito do Amor Selvagem. In: Prismas do Teatro - p. 231-235. 
Livremente baseado em Nações Unidas, o texto teatral de Agrippino escrito em 1966, o espetáculo rapidamente toma durante os ensaios características múltiplas a partir dos improvisos dos atores - algo, aliás, já previsto no próprio texto que, paradoxalmente, foi escrito para estar ausente, ou melhor, para, estando presente, testemunhar seu próprio desgaste, sua desimportância eletiva. Dando assim primazia a montagens simultâneas de elementos cênicos, acreditava-se numa anulação da relação sujeito/objeto cristalizada na estrutura platéia/espetáculo. Apostava-se, para tanto, no esquema já comentado por mim de alternar cenas preparadas com “interrupções" aleatórias que extrapolavam os limites do palco, acontecendo muitas vezes no meio do público como um convite para um jogo de significações. No centro desse trabalho está o ator como um encenador do seu próprio corpo.

Foi necessário, desse modo, dar ao rito para além de seus improvisos e de suas interrupções uma habilidade corporal razoavelmente apreensível - por isso a escolha de um ator profissional de reconhecidos dotes físicos como Stênio Garcia para o papel principal do espetáculo. Stênio, ator formado pelo Conservatório Nacional de Teatro do Rio de Janeiro com dez anos de experiência no teatro profissional, participava de boa parte das cenas garantindo a tal experimento cênico permeado de amadores e neófitos um mínimo de instrumentalização técnica ao encarnar ele próprio a figura do ator-soma ${ }^{245}$, essa experiência de uma exacerbação da expressividade corporal encravada numa dramaturgia de acasos, ruídos e fragmentos. Em Stênio, o sujeito autônomo da representação que Agrippino havia suprimido na passagem de Lugar Público a Panamérica reaparece por instantes apenas para contemplar sua transubstanciação em carne, explícita na grande bola de plástico que em sua luminosa transparência era atirada do palco para a platéia (e vice-versa) em todo final de espetáculo, selando assim o teatro como essa nova comunhão vital dos desejos.

Assim sendo, a nova década que se anuncia não chega sem sobressaltos. No auge da repressão militar do governo Médici, em meio a paranóia generalizada pela prisão de amigos próximos (e distantes), Agrippino e Maria Esther optam por deixar o país. Ao contrário, no entanto, de 245 A expressão foi cunhada por Maria Thaís Lima Santos no seu trabalho A Interpretação no Brasil: linguagem corporal e os novos procedimentos cênicos 1970/1971 - p. 107. 
outros artistas e intelectuais em situação semelhante, não escolhem como lugar para o exílio algum dos grandes centros mundiais da contracultura como Londres, Paris ou Nova York - preferem a África, o grande ventre negro. Essa escolha é bastante significativa naquilo que nos revela do esgotamento das vanguardas metropolitanas e sua reorientação para uma arte francamente antropológica que busca agora um conceito de imagem que não distingua mais o ser da aparência (o pecado original dos gregos). Para além do rito há o Grande Rito, o continente mãe, de onde todas as coisas vieram e pra onde todas elas devem voltar. ${ }^{246}$

A jornada de Agrippino e Maria Esther se inicia com pequenos filmes em Super-8 de rituais de candomblé no Dahomey e no Togo. São registros dessa grande energia mística e religiosa que une os dois lados do atlântico, além de uma experiência aflorada com o ritmo e o povo das muitas áfricas, onde vemos Maria Esther, a bailarina mestiça (com seu semblante índio) filha das elites endinheiradas, deixando-se absorver pela alegria e a força dos tambores e cânticos, recebendo à benção (às vezes desconfiada, mas sempre generosa) dos filhos da terra. Esses registros iniciais adquirem uma feição mais substancial com o média metragem de 1972 denominado simplesmente Maria Esther: danças na África; com ele, vemos como a arte-soma dos anos 60 transmutou-se numa "utopia doméstica" de sons e sentidos.

Intercalada por pequenas cenas do cotidiano do casal e por imagens das ruas e das praias da costa africana, vemos nesse filme basicamente Maria Esther dançando dentro de uma casa modesta. As tomadas são simples e se concentram no transe e na gestualidade da bailarina. Divido essas tomadas em dois grupos: as tomadas interiores, feitas dentro da casa, e uma sequência externa filmada, aparentemente, num teto (talvez o teto desta mesma casa). No primeiro grupo, particularmente interessantes são as tomadas que mostram Maria Esther dançando, desnuda da cintura para cima, iluminada apenas pelos raios de sol que invadem a casa tanto pela porta aberta quanto pela janela sem cortinas. A câmera, oscilando entre o corpo extático de Maria Esther e alguns objetos da

246 Uma busca, em certo sentido, comum há muitos artistas de vanguarda - basta lembrarmos Gaguin, por exemplo, e seu retiro na Polinésia. A questão toma outra figura nos anos 70, quando o movimento é histórico, significando um "cansaço generalizado" com a narrativa tradicional da história da arte que culmina com sua aproximação (ou diluição) cada vez maior nos estudos culturais e antropológicos. 
casa, nunca perde de vista, ao fundo, transbordando em luminosidade, o oceano atlântico. Essa junção do cenário doméstico (a casa com seus objetos), a paisagem (a praia, o mar) e a dança é fundamental para consolidar essa imagem de um "ser no mundo e com ele", onde a vida social não se separa da natureza e dos ritos. A montagem contribui para esse cerimonial ontológico na medida em que alterna às danças de Esther, tomadas externas como aquela bela sequência na praia onde vemos os corpos negros de crianças africanas brincando na água em franco contraste de luz com o mar cintilante de fagulhas prateadas - tudo isso acolhido pelo som dos orixás, já que durante todo o filme não deixamos em nenhum momento de ouvir na banda sonora cantos e músicas de acentuado apelo rítmico, como se a dança dos meios (dos fotogramas; dos planos) fosse um imperativo para a constituição do filme: não se confia numa imagem que não dança.

$\mathrm{Na}$ outra sequencia destacada por mim, aquela em que vemos Esther dançando no teto da casa, o foco recai em planos contra-picados que colocam a figura da bailarina em constante contraposição ao azul celeste ao fundo, deslocando a epifania universal das formas do mar para o céu. Por vezes, esse azul é surpreendido pelo branco ruidoso das paredes e da marquise, que tentam enquadrá-lo no seu desvario, mas que por sua vez acabam elas próprias (des)enquadradas pela fatura angulosa dos planos que recortam a arquitetura da sua funcionalidade espacial, fazendo-a servir ao acontecimento. Daí que Agrippino não tenha pudores em mostrar, por vezes, as antenas de TV que recobrem os tetos da casas populares ao redor: elas também são parte desse novo mundo de deuses e monstros que está sendo gestado naquelas danças parturientes.

Como um idílio artístico e existencial, Maria Esther: danças na África é o registro singular desse momento em que o casal assume inteiramente o projeto de transformar sua estética coletiva da arte-soma numa ética da vida em comunidade. Assim, esse pequeno filme caseiro toma o lugar das engenhosas "obras de arte" como a promessa de uma imagem que não se distingue mais da vida imagética comum aquelas pessoas, sendo, por isso mesmo, uma tentativa de destruição da presença de um medium em que se estabelece tais imagens ou ao menos da transformação desse medium num objeto entre outros que partilham dessa dança que nunca cessa - daí a dimensão lúdica 
com que Agrippino brinca, por vezes, com a câmera, fazendo-a rodar pelo espaço, flutuar entre os , para enfim acabar encontrando ele próprio como o olho por trás desse olhar mecânico. O que se busca é que essas imagens não sejam mais a mera presença de uma ausência, essa morte a 24 quadros por segundo, mas que assumam sempre o risco da ressurreição (a dança). É na volta da África para o Brasil (e como podia ser diferente) que esse renascimento se completará, mais especificamente no curta-metragem de 1978 intitulado Céu sobre Água. Ali, acompanhando desde a gestação até os primeiros passos de um dos filhos do casal, essa "arte-soma" que se apresenta sempre como o próprio limite do mundo chega a seu ponto máximo como utopia de ressurreição do corpo. ${ }^{247}$

Céu sobre Água (20") começa com um plano pregnante: tendo ao fundo o céu azul de Cabral, duas pernas com os pés apontando para este céu se abrem revelando o sexo feminino. Em suaves compassos elas se movem, desenhando longas silhuetas no ar até que o sexo desnudo, a esquerda do quadro, receba algumas réstias de luz que escapam por detrás das bordas do corpo. É como se a dança, o movimento das pernas, fosse capaz de traçar pelo espaço esculturas de luz e sombra. A diagonal dramática da ascensão é invocada no quadro: da esquerda baixa para a direita alta, onde estão os pés. O sexo nu, assim como as nádegas depois, contraposto a dimensão infinda do horizonte ganha então uma forte simbologia cósmica, como se tal dança fosse um primeiro rito de fertilidade transcendental, uma abertura para corpo expandido da Nova Era. Por sua vez, a proximidade tátil que o foco tem com seu objeto, a aspereza do corpo, obriga o fundo a saltar para a superfície da tela, num movimento inverso, em que o espaço indeterminado, o céu azul, se consubstancia na pele da câmera - a epiderme do texto. É o começo dessa relação íntima e afetiva entre os elementos: o céu, a água, a luz, o corpo.

Depois, temos uma longa sequência de planos na água. Comparado ao azul diáfano do céu, o azul da água é denso e quente - conta-se uma anedota, que deve ter muito de verdade, que Agrippino passava horas, senão dias, para alcançar a temperatura ideal da água capaz de oferecer a palheta de cores que ele gostaria. Imersos na água, vemos corpos e rostos numa interação 247 Daí a forte impressão do crítico Rubens Machado Jr. de que Céu sobre Água seja o filme brasileiro mais hippie que ele conhece, talvez o único. 
lúdica com o azul. Dentre todos eles, destaca-se a mulher grávida, Maria Esther, inteiramente envolta pela água, ela se banha em seu próprio líquido amniótico. Saímos da esfera da fertilização e nos encaminhamos para a gestação. Nesse sentido, temos uma imagem-síntese que merece destaque: em primeiro plano pictórico vemos a barriga; no centro, em perspectiva, uma linha de coqueiros; acima e ao fundo, o azul do céu que se reflete na água. Numa segunda tomada, mais aproximada, a barriga ganha volume ocupando agora toda a metade inferior do quadro, suas bordas quase tocam a linha de coqueiros. Essa "geografização" da maternidade alinha os limites do mundo aos limites da matériaviva: o corpo se escreve junto com a natureza - a existência é o ser-no-mundo.

Em águas mais rasas, a luz alcança o fundo e ferve em tonalidades graves, avermelhadas, assim como os corpos, na tez ocre das tardes. O movimento das mãos de Maria Esther à flor da água gera inesperados efeitos de luz. Aos poucos, todo seu corpo se enche de riscos luminosos, como se os espectros forjados a superfície da água percorressem-se feito veias uma materialidade orgânica que não se distingue mais da luminosidade e da liquidez. Para entender essa pesquisa formal de Agrippino como colorista é preciso lembrar que no cinema a luz está presente duplamente: como luz projetada e como luz registrada. Daí seus esforços em encontrar a temperatura correta para forjar uma expressão luminosa. No cinema, a primazia é da luz, não da cor - a primazia da cor pertence a pintura. Para o pintor, fazer da luz um "material plástico" é uma necessidade, para o cineasta é algo difícil e deliberado, foi isso o que nos ensinou Jacques Aumont ressaltando ainda que em relação a história da pintura, o cinema significou um afastamento do "unicamente visual", ganhando em novas significações e problematizando a autonomia dos valores plásticos, especialmente a partir de sua dimensão narrativa. ${ }^{248}$ Agrippino e Maria Esther parecem querer dar um passo adiante: transfigurar o cinema num teatro de pintores, numa performance do olhar que não se contenta em simplesmente "representar" a ação, mas busca uma imagem re-criada onde os corpos entretém sua relação essencial com o indeterminado. Isso fica claro num terceiro momento do filme: a sequencia de planos que nos mostram uma criança sobre um espelho, vista como um imagem invertida, tendo ao 
fundo o mesmo céu límpido. Se começamos na fertilização e passamos pela gestação, chegamos agora ao nascimento. Com dificuldades, a criança tenta botar-se em seus próprios pés, tenta andar, relacionar-se com o mundo. Não é ela, no entanto, que vai erguer-se e afirmar-se, é o filme que o fará.

A imagem, a imitação, é essa continua tentativa de descortinar o véu de Maia que recobre a realidade: é a rememoração de uma ancestral união desfeita. Por outro lado, a imagem é igualmente essa constante criação de duplos que acabam agindo contra a vida. Nesse bloco de cenas de "Céu sobre Água" em que a criança é vista "através do espelho", cabe a essa inversão de perspectiva desrealizar a diegese colocando a câmera "no mundo", jogando um duplo contra outro na ânsia de impedir o conhecido fenômeno da ficção realista em que o dispositivo ordena um cenário de ações coerentes. Nesse filme de Agrippino e Maria Esther não há imagens de pessoas sem que estas estejam ou despersonalizadas pela natureza (contrapostas ao céu, imersas na água) ou refletidas nela de algum modo (silhuetas, reflexos na água) - aquele que só eu sou se desmancha e se refaz continuamente no ritmo da água, no fluir do tempo. Uma imagem não é um signo, não deve ser soprada para longe do corpo, deve ser uma força pura que age sobre o espírito. Um filme não é um filme, ele é um encontro. Essa criança que se põe em pé, num novo levantar-se, e que em breve vai ensaiar as primeiras palavras, deve fazê-lo não como quem interpola e interpreta o mundo, mas como aquele que nasce sempre uma outra vez mais para e com ele.

Filma-se, assim, essa criança entre agapés. A câmera então lentamente abandona a criança e se movendo por sobre o azul impassível das águas chega até a linha de coqueiros no horizonte. Esse enquadramento sempre invocado parece implicar numa trancendência, numa vontade de unir aquilo que aparece separado: o céu e a terra. Em seguida, a câmera perfaz um amplo movimento circular, como se sublinhasse o espaço em volta da criança. O Panorama é sempre dúbio em seus significados: ao mesmo tempo que nutre o olhar com o longínquo, com a fuga das paisagens, ele o aprisiona definitivamente, delimita o seu espaço, termina-o, fecha-o em si. No plano seguinte de "Céu Sobre Água" estamos de volta aquela linha de coqueiros dividindo o horizonte: a ameaça da perspectiva atualiza-se. Só que agora temos um dado novo: a frente desta "vista" temos a criança 
sentada e como a câmera a captura de modo bem aproximado, percebemos que a figura da criança claramente rompe os limites do horizonte e se imiscui entre o céu e a terra. Lembremos que isso não acontecia antes, quando esse mesmo enquadramento nos mostrava a barriga grávida circunscrita a metade inferior do quadro, de modo que implicações são evidentes: o filme, através de suas invenções de linguagem, coloca-se em seus próprios pés, coisa que a criança ainda não faz, mas justamente para apontar que a única transcendência possível está na criança, na criação do corpo - separada desta, não há nada. A criança é a lógica do movimento e da sensação, antes das representações, antes da gramática operacional (se quisermos lembrar o tão vilipendiado vocabulário de Piaget).

Ao contrário do que pode parecer a primeira vista, "Céu Sobre Água" não é, portanto, uma obra formalista, preocupada exclusivamente com tonalidades e jogos de luz, pelo contrário, é uma obra impregnada de espiritualidade, mas não num sentido tradicional, dualista, da alma contra a matéria, aqui é o corpo o próprio tempo da transcendência - estamos diante de uma metafísica da carne. Nas cenas seguintes, a criança engatinha, toca o solo, toca a água que rebrilha a sua volta, numa utopia carnal de luz e cor. Depois ela aparecerá mamando, descobrindo com as mãos os desvãos sinuosos da mãe: a pele, a terra, a água surgem na tela como a fonte primária dos desejos, das forças puras, da vida.

É preciso destacar igualmente o uso da música no filme: durante toda a duração da película ouvimos um instrumental de cítaras indianas e seus requintados intervalos microtonais, muito distantes da voluptuosa e semitonada escala cromática, principal artífice dessa obsessão melódico-harmônica que caracteriza a sinfonização ocidental e que desde pelo menos o "momento feliz" dos gregos antigos vem nos proporcionado uma música das esferas, onde os valores sonoros se coadunam com a construção platônica do ideal. Meditativamente, tema e desenvolvimento são substituídos pela livre repetição: é preciso que as vibrações da dança sempre renovada de Shiva repercutam pelos abismos do corpo (ele próprio abismal) feito relâmpagos, como as variações estesiantes que revestem e desnudam sucessivamente o esqueleto nu do raga (a sequencia melódica única). Da mesma forma, o céu interessa a Agrippino sobretudo por sua imagem refletida sobre a 
água, pelos nuances de suas vibrações e imanações, assim como aquilo que nos coloca sempre diante da essência do cinema são essas imagens evanescentes e as fortes sensações que elas causam sobre o espectador.

Entender esse límpido movimento dos seres e das almas, essa possibilidade de um instante sensório proporcionar ao expectador um momento sublime de epifania e espanto é, enfim, compreender do que trata o cinema. Mas não um cinema de "choques", que atrela o "movimento fragmentário do filme a uma presença imaginária do movimento real", ${ }^{249}$ como se fora uma espécie de reação estética a experiencia mais ampla de fragmentação (epistemológica) da modernidade. Não um cinema de descontinuidades que no interior do espectador tornam-se novamente continuidade (o “todo" sensório-motor) - daí eu evitar a expressão fotogenia, que parece vir carregada desses signos. Mas um cinema onde cada instante seja não a dialética imobilizada (Benjamin), nem a verdade do presente como ele é (Epstein), mas a condição de possibilidade para o corpo descobrir-se um espaço não aprisionado pelo ente. No filme de Agrippino e Maria Esther, o tempo não pode ser uma sucessão de agoras, mas sim uma abertura para o assombro - a Arte-Soma não representa o mundo, mas funda um mundo que durante algum tempo resiste àquilo que encerra-a-si-mesmo. A transcendência do filme está em aspirar que esse mundo torne-se um só reino: a vida.

Assim, a sequência final do filme abre-se com um plano de nuvens, logo após, vemos novamente o corpo feminino nu à flor da água, percebemos que a mulher não está mais grávida - ela se movimenta suavemente, dançando e fazendo a àgua e a luz dançarem para a câmera. $\mathrm{O}$ nascimento é justamente aquilo que traz o universal para o mais ínfimo dos particulares. É o delírio do silogismo. Num plano mais longo, vemos então a imensidão do céu azul, aos poucos a câmera vai descendo e a borda inferior do quadro vai revelando primeiro a linha de coqueiros e depois, espremida no canto inferior direito do quadro, a mulher que traz pelas mãos a criança. Esta dá os seus primeiros passos, ainda apoiada na mãe e, como nos revela finalmente a câmera, anda com os pés na água rasa. O mais notável é que de maneira nenhuma o enquadramento recupera o centro de simetria típico do 249 CHARNEY. Num instante: o cinema e a filosofia da modernidade. In: CHARNEY, L \& SCHWARTZ, V. (org) O Cinema e a Invenção da Vida Moderna - p. 332. 
estilo clássico, esse reforço do caráter ativo das bordas parece ter a mesma dimensão formal da reduplicação reflexiva que Agrippino experimentou ao filmar a criança através do espelho: ao deslocar a figura humana, ele reforça a superfície, afastando o chamado efeito-janela do quadro psicológico e realizando o paradoxo de separar o filme de seu "fora-de-campo". Não deve existir um espaço euclidiano que exista anteriormente aos seus personagens: o homem está no mundo e nasce com ele. Em alguns poucos planos restantes, vemos os pés da criança brincando dentro da água, depois vemos seu sexo, é uma menina - a edificação edipiana é confrontada pela dimensão uterina da novidade. Corte para o sexo da mãe dentro da água, o último plano do filme: a marcha das utopias segue rumo ao Matriarcado definitivo, seja ele o despertar de Aquarius ou das diatribes oswaldianas.

Das areias e águas de Arempebe, ainda hoje considerado o último reduto hippie do Brasil, saiu este filme único, uma experiência para todos e para ninguém; mal parida a utopia, como de praxe, acabou levada pelo vento, se perdendo nas dunas do agreste baiano. Poucos anos depois, a união do casal se desfaz. Sem Maria Esther, Agrippino não voltará mais a realizar nenhum trabalho artístico, mesmo cultivando até a morte longos cadernos com um tipo de prosa altamente idiossincrática (que talvez um dia acabe publicada como o testamento "genial" de um poeta louco, sabemos o quanto as casas editoriais adoram essas presepadas). Fato é que Agrippino foi se calando, se calando... Quiseram depois que ele falasse, mas ele não disse nada com nada, e esse foi seu último grande acontecimento: um espanto discreto com a possibilidade de algo ser dito e não nada. Agrippino não compactuou com a aura de profeta do contemporâneo que atribuíram a ele, e isso por um motivo muito simples: o ciclo começado com Lugar Público se fecha em Céu Sobre Água - a "arte-soma" floresce na Panamérica utópica e perpassa o estrondo do Rito para desmanchar-se como um gemido em Super-8. Agrippino não encontrou lugar para sua arte no cinismo deliberado dos anos 80: seu horizonte era o amanhã e não $o$ pós, seu corpo dispensou qualquer anistia e sua poesia não se mostrou disposta a redimir ninguém perante a eternidade. Ela é apenas um grande espanto. O resto é macumba pra turista. 


\section{Bibliografia Geral}

ADORNO, T. \& HORKHEIMER, M. Dialética do Esclarecimento: fragmentos filosóficos. Rio de Janeiro, Jorge Zahar, 2006.

ANDRADE, Oswald de; A Utopia Antropofágica. São Paulo, Ed. Globo, 1995.

AUSTIN, J. L. How to Do Things with Words. Cambridge, Harvard University Press, 1962.

BARTHES, Roland; Mitologias. Rio de Janeiro, Difel, 2007.

BAUDELAIRE, Charles; The Painter of Modern Life and Other Essays. London, Phaidon, 1964.

BAUDRILLARD, Jean; Le Crime Parfait. Paris, Galilée, 1995.

CAMPBELL, Joseph; The Hero with a Thousand Faces. Princeton, PUP, 1973.

CAMUS, Albert; Le Mythe de Sisyphe: essai sur l'absurde. Paris, Gallimard, 1965.

DANTO, Arthur. Após o Fim da Arte: a arte contemporânea e os limites da história. São Paulo, Edusp, 2006. A Transfiguração do Lugar-comum. São Paulo, Cosac \& Naify, 2004.

DEBORD, Guy. A Sociedade do Espetáculo. Rio de Janeiro, Contraponto, 2006.

DELEUZE, Gilles. Crítica e Clínica. São Paulo, Ed. 34, 2004.

Diferença e Repetição. Rio de janeiro, Graal, 2006.

DERRIDA, Jacques; A Escritura e a Diferença. São Paulo, Perspectiva, 1995.

ECO, Umberto; Apocalípticos e Integrados. São Paulo, Perspectiva, 2004.

FOUCAULT, Michel; Microfísica do Poder. Rio de Janeiro, Graal, 1981.

FRANCASTEL, Pierre; A Realidade Figurativa. São Paulo, Perspectiva, 1993.

GREENBERG, Clement; Vanguarda e Kitsch. In: (org) FERREIRA, G. \& MELLO, C. Clement Greenberg e o Debate Crítico. Rio de Janeiro, Jorge Zahar, 2001.

HANSEN, J. Adolfo; Pós-moderno e Cultura. In: CHALHUB, Samira (org.) Pós-moderno \&. Rio de Janeiro, Imago, 1994.

HEGEL, G. W. F. Cursos de Estética - IV. São Paulo, Edusp, 2004.

HEIDEGGER, M. Que é Metafisica? São Paulo, Duas Cidades, 1969.

HUYSSEN, Andreas; Mapeando o Pós-moderno. in: HOLANDA, Heloísa Buarque (org.) Pós-modernismo e política. Rio de Janeiro, Rocco, 1991.

JAMESON, Frédric; Pós-modernidade e Sociedade de Consumo. São Paulo, Revista Novos Estudos Cebrap n ${ }^{\circ}$ 12, jun. 1985. 
JOLLES, André; Formas Simples. São Paulo, Cultrix, 1976.

KRAUSS, Rosalind. A Voyage on the North Sea: art in the age of post-medium condition. London, Thames \& Hudson, 2000.

LÉVI-STRAUSS, Claude. Antropologia Estrutural II. Rio de Janeiro, Tempo Brasileiro, 1993.

LIPPARD, Lucy; A Arte Pop. São Paulo, Verbo / Edusp, 1976.

LYOTARD, Jean-François; Discurso, figura. Barcelona. G. Gili, 1979.

O Pós-moderno Explicado as Crianças: correspondência 1982-1985. Lisboa, Dom

Quixote, 1993.

MCLUHAN, M. Os Meios de Comunicação como Extensões do Homem. São Paulo, Cultrix, 1971.

MARTINS, Wilson; História da Inteligência Brasileira, v. VII. São Paulo, T. Queiroz, 1992.

MERLEAU-PONTY, Maurice; O Olho e o Espírito. São Paulo, Cosac \& Naify, 2004.

NIETSZCHE, F. Considerações Extemporâneas. Lisboa, Editorial Presença/Martins Fontes, 1980. Assim Falou Zaratustra: um livro para todos e para ninguém. Rio de Janeiro, Bertrand Brasil,

1995.

PANOFSKY, Erwin; La Perspective Comme Forme Symbolique et Autre Essais. Paris, Éditions de Minuit, 1975.

PAZ, Octávio; Marcel Duchamp ou o castelo da pureza. São Paulo, Perspectiva, 2002.

RIDENTI, Marcelo; Em Busca do Povo Brasileiro: artistas da revolução, do CPC à era da TV. Rio de Janeiro, Record, 200.

SALIBA, E. T. Raizes do Riso: a representação humorística na história brasileira: da Belle Époque aos primeiros tempos do rádio. São Paulo, Cia das Letras, 2002.

SEARLE, John; Os Actos de Fala: um ensaio de filosofia da linguagem. Coimbra, Almedina, 1981.

SONTAG, Susan; Contra a Interpretação. Porto Alegre, LP\&M, 1987.

VENTURI, R. \& BROWN, D. S. \& IZENOUR, S. Aprendendo com Las Vegas: o simbolismo (esquecido) da forma arquitetônica. São Paulo, Cosac \& Naify, 2003.

VELOSO, Caetano; Verdade Tropical. São Paulo, Cia das Letras, 1997.

WHITE, Hayden; Trópicos do Discurso: ensaios sobre a crítica da cultura. São Paulo, Edusp, 2001.

WISNIK, J. M. O Som e o Sentido: uma outra história das músicas. São Paulo, Cia das Letras, 2007.

WOOD, Paul; Arte Conceitual. São Paulo, Cosac \& Naify, 2002. 


\section{Cinema, Teatro e Performance}

ABEL, Richard (org) Silent Film. New Brunswick, Rutgers University Press, 1996.

ALBERA, François. Eisenstein e o construtivismo russo. São Paulo, Cosac \& Naify, 2002.

ARTAUD, Antonin; Linguagem e Vida. (org.) GUINSBURG, J. \& TELESI, S. São Paulo, Perspectiva, 2006.

O Teatro e seu Duplo. São Paulo, Martins Fontes, 1999.

AUMONT, Jacques; O olho Interminável: cinema e pintura. São Paulo, Cosac \& Naify, 2004.

AUSLANDER, Phillipe; From Acting to Performance: essays in modernism and postmodernism. London, Routledge, 1997.

AVELLAR ,José Carlos; O Cinema Dilacerado. Rio de Janeiro, Alhambra, 1986.

BAZIN, André; O Cinema: Ensaios. São Paulo, Brasiliense, 1991.

BERNARDET, J.C. Brasil em Tempo de Cinema. São Paulo, Cia das Letras, 2007.

O Vôo dos Anjos: Bressane, Sganzerla. São Paulo, Brasiliense, 1991.

BORDWELL, D. \& STAIGER, J. \& THOMPSOM, K. The Classical Hollywood Cinema: film style and mode of production to 1960. London, Routledge, 1988.

BRECHT, Bertold. Diário de Trabalho. Rio de Janeiro, Rocco, 2005.

BUTLER, Judith; Performative Acts and Gender Constitution: an Essay in Phenomenology and Feminist

Theory. In: HUXLEY, E. \& WITTS, N. (org.) The Twentieth-Century Performance Reader. London, Routledge, 1996.

CARLSON, Marvin; Performance: a critical introduction. New York, Routledge, 2004.

CHARNEY, L \& SCHWARTZ, V. (org) O Cinema e a Invenção da Vida Moderna. São Paulo, Cosac \& Naify, 2004.

COHEN, Renato; A Arte da Performance. São Paulo, Perspectiva, 2002.

COSTA, Cláudio da; Cinema Brasileiro (anos 60-70): dissimetria, oscilação e simulacro. Rio de Janeiro, 7 Letras, 2000.

DELEUZE, Gilles; Cinema II: A Imagem-Tempo. São Paulo, Brasiliense, 1990.

DUBOIS, Phillipe; Cinema, Video, Godard. São Paulo, Cosac \& Naify, 2004.

EISENSTEIN, Serguei; A Forma do Filme. Rio de Janeiro, Jorge Zahar, 2002. O Sentido do Filme. Rio de Janeiro, Jorge Zahar, 2002.

FÉRAL, Josette; La Performance ou Le Refus du Theatre. Protée (Théorie and Pratiques) nº 17, 1989. 
Performance et theatralité: le sujet demystifié. In: (org.) Théâtralité, écriture et mise en scène. Quebec, Hurtubise, 1985.

FERREIRA, Jairo; Cinema de Invenção. São Paulo, Max Limonad, 1986.

GERBER, Raquel. O Mito da Civilização Atlântica: Glauber Rocha, cinema, política e estética do inconsciente. Petrópolis, Vozes, 1982.

GLUSBERG, Jorge; A Arte da Perfomance. São Paulo, Perspectiva, 2007.

GUENOUN, Pierre; O Teatro é necessário? São Paulo, Perspectiva, 2004.

JAMESON, Frédric; O Método Brecht. Petropólis, Vozes, 1999.

KAPROW, Alan. Assemblage, Enviroments and Happenings. New York, Abrams, 1965.

LEHMANN, Hans-Thies; Teatro pós-dramático. São Paulo, Cosac \& Naify, 2007.

MACHADO Jr, Rubens; Estudo sobre a Organização do Espaço em Terra em Transe. Tese de Doutorado em Cinema, TV e Rádio - ECA/USP, São Paulo, 1997.

MADAZZIO, Irlany; O Vôo da Borboleta: a obra cênica de José Agrippino de Paula e Maria Esther Stocker. Dissertação de Mestrado em Artes Cênicas - ECA/USP, São Paulo, 2006.

METZ, Christian; A Significação no Cinema. São Paulo, Perspectiva, 2006.

RAMOS, Fernão; Cinema Marginal (1968 - 1973): a representação em seu limite. São Paulo, Brasiliense, 1987.

(org.) Teoria Contemporânea do Cinema (volumes 1 e 2). São Paulo, Senac, 2005.

ROCHA, Glauber; Revisão Crítica do Cinema Brasileiro. São Paulo, Cosac \& Naify, 2003.

Revolução do Cinema Novo. São Paulo, Cosac \& Naify, 2004.

SANTOS, Maria Thais Lima; A Interpretação no Brasil: linguagem corporal e os novos procedimentos cênicos 1970/1971. Dissertação de Mestrado em Artes Cênicas - ECA/USP, São Paulo, 1994.

SCHECHNER, Richard; Performance Studies: an introduction. New York, Routledge, 2006.

SGANZERLA, Rogério; Por um Cinema sem Limites. Rio de Janeiro, Azougue, 2001.

Sganzerla - série encontros. (org.) CANUTO, Roberta; Rio de Janeiro, Azougue, 2007.

XAVIER, Ismail; Alegorias do Subdesenvolvimento: cinema novo, tropicalismo, cinema marginal. São Paulo, Brasiliense, 1993.

Cinema Brasileiro Moderno. São Paulo, Paz e Terra, 2001. 
O Olhar e a Cena: Hollywood, cinema novo e Nelson Rodrigues. São Paulo, Cosac \& Naify,

2003.

Sertão Mar: Glauber Rocha e a estética da fome. São Paulo, Cosac \& Naify, 2007. (org.) A Experiência do Cinema: antologia. Rio de Janeiro, Graal, 2008.

\section{Crítica e Teoria Literária}

AUERBACH, Erich; Mimesis: a representação da realidade na literatura ocidental. São Paulo, Perspectiva, 2007.

ÁVILA, Henrique M. Da Urgência e da Aprendizagem: sentido da história e romance brasileiro nos anos sessenta. Londrina, UEL, 1997.

BAKHTIN, Mikhail; A Cultura Popular no Renascimento e na Idade Média: o contexto de François Rabelais. São Paulo, Hucitec / Annablume, 2002.

Questões de Literatura e de Estética: a teoria do romance. São Paulo, Hucitec /

Annablume, 1998.

BOSI, Alfredo; História Concisa da Literatura Brasileira. São Paulo, Cultrix, 2001.

BUTOR, Michel; Repertório. São Paulo, Perspectiva, 1974.

CAMPOS, Haroldo de; Serafim: um grande não livro. In: ANDRADE, Oswald de; Serafim Ponte Grande. São Paulo, Ed. Globo, 2007.

CÂNDIDO, Antônio; Brigada Ligeira. Rio de Janeiro, Ouro sobre Azul, 2004. A Educação pela Noite. Rio de Janeiro, Ouro sobre Azul, 2006.

GIL, Fernando C. O Romance da Urbanização. Porto Alegre, EDIPUCRS, 1999.

HOISEL, Evelina. Supercaos: os estilhaços da cultura em Panamérica e Nações Unidas. São Paulo, Civilização Brasileira, 1980.

HUTCHEON, L. Poética do Pós-modernismo: história, teoria e ficção. Rio de Janeiro, Imago, 1991.

LUKÁCS, G. A Teoria do Romance: um ensaio histórico-filosófico sobre as formas da grande épica. São Paulo, Duas cidades / Ed. 34, 2009.

MILLIET, Sérgio; Diário Crítico v. II. São Paulo, Edusp/Martins Livraria, 1981. 
NUNES, Benedito. A Visão Romântica in: GUINSBURG, J. (org.) O Romantismo. São Paulo, Perspectiva, 1993.

ROBBE-GRILLET, Alain; Por um Novo Romance. Lisboa, Publicações Nova Europa, 1965.

ROSENFELD, Anatol. Prismas do Teatro. São Paulo, Perspectiva, 2000.

ROSENTHAL, Erwin T. O Universo Fragmentário. São Paulo, Cia Editora Nacional, 1975.

SARRAUTE, Nathalie; L'ère du Soupçon: essays sur le roman. Paris, Gallimard, 1956.

SARTRE, J. P. Que é a Literatura? São Paulo, Ática, 2004.

Préface. In: SARRAUTE, N. Portrait d'un Inconnu. Paris, Union Generale D'editions, 1964.

SCHWARZ, Roberto. A Sereia e o Desconfiado. Rio de Janeiro, Paz e Terra, 1981.

SZONDI, Peter. Ensaio Sobre o Trágico. Rio de Janeiro, Jorge Zahar, 2004.

WATT, Ian; Ascensão do Romance: estudos sobre Defoe, Richardson e Fielding. São Paulo, Cia das Letras, 2007.

\section{Romances e outras ficções}

AGRIPPINO DE PAULA, José; Lugar Público. São Paulo, Papagaio, 2004.

Panamérica. São Paulo, Papagaio, 2001.

AGUILAR, José Roberto; A Divina Comédia Brasileira. São Paulo, Livraria Cultura Editora, 1981.

BORGES, J. L. Ficções. São Paulo, Cia das Letras, 2007.

BRANDÃO, Ignácio de Loyola. Bebel que a cidade comeu. São Paulo, Global Editora, 2001.

JOYCE, James. Ulisses. Rio de Janeiro, Civilização Brasileira, 2000.

KANIUK, Yoram; Adam filho de cão. São Paulo, Globo, 2003.

LISPECTOR, Clarice. Perto do Coração Selvagem. Rio de Janeiro, Francisco Alves, 1990.

MAUTNER, Jorge; Mitologia do Kaos (volumes 1 e 2). São Paulo, Azougue, 2002.

SARTRE, J. P. A Náusea. São Paulo, Altaya / Record, 1996. 


\section{Filmografia de José Agrippino de Paula}

\section{Curtas}

Candomblé no Dahomey (Fetichismo do Sul do Dahomey) - 1971

Candomblé no Togo (Mãe de Santo Djatassi) - 1971

Timbuctu e Moptil (1972)

\section{Céu Sobre Água (1978)}

direção e fotografia: José Agrippino de Paula

danças e coreografia: Maria Esther Stockler

Montagem: José Agrippino de Paula

Música: Ravi Shankar

Arempebe. 20 minutos. Super-8. Colorido.

\section{Média}

\section{Maria Esther: Danças na África (1972)}

direção: José Agrippino de Paula e Maria Esther Stockler

fotografia: José Agrippino de Paula

performance: Maria Esther Stockler

montagem: José Agrippino de Paula

África. 40 minutos. Super-8. Colorido.

\section{Longa}

\section{Hitler III ${ }^{\circ}$ Mundo (1968)}

produção, roteiro e direção: José Agrippino de Paula

fotografia e câmera: Jorge Bodansky

Assistente de câmera: Hermano Penna

montagem: Rudá de Andrade e Walter Luís Rogério

Cenografia: Sebastião de Souza

Música: Ivan Mariotti e Judimar Ribeiro

Elenco: Jô Soares, José Ramalho, Eugênio Kusnet, Luiz Fernando Resende, Túlio de Lemos, Sílvia Werneck, Maria Esther Stockler, Ruth Escobar, Jairo Salvini, Danielle Palumbo, Jonas Mello, Carlos Silveira, Fernando Benini, Manoel Domingos.

São Paulo. 70 minutos. $16 \mathrm{~mm} . P \& B$. 


\section{Espetáculos do Sonda}

\section{Tarzan III ${ }^{\circ}$ Mundo - O Mustang Hibernado (1968)}

Direção de Cena: José Agrippino de Paula

Coreografia e Preparação Corporal: Maria Esther Stockler

Roteiros: José Agrippino de Paula (cenas: "Tarzan III ${ }^{\circ}$ Mundo" e "Paz Mundial"); Jô Soares (cena: "A Dupla Dinâmica”), Efízio Putzolu (cena: “O Homem Hibernado"); Sarah Feres (cena: "Luta")

Cenários e Figurinos: José Agrippino de Paula, Efízio Putzolu e Sarah Feres.

Música e Sonoplastia: Adam Cadmon (com a participação de Roberto de Souza)

Equipe de Produção: Carlos Eugênio de Moura, Eloy de Araújo e Gabriela Rabelo

Iluminação: Carlos Alberto Ebert e José Agrippino de Paula

Elenco: Dimas Coutinho, Carlos de Moura, Manuel Domingues Filho, Yolanda Amadei, Luis Fernando Resende, Annabela, Fernando Benini, Oiá Guaraci, Danielle Palumbo, Maria Esther Stockler e demais bailarinos.

Apresentado no I Festival Paulista de Dança realizado no Teatro Anchieta do Sesc Consolação em Outubro de 1968; em dezembro desse mesmo ano o espetáculo teve também uma curta temporada no Teatro Maria Della Costa.

\section{O Planeta dos Mutantes (1969)}

Coreografia e Direção: Maria Esther Stockler

Roteiro e Produção: José Agrippino de Paula e Os Mutantes.

Cenografia, Figurinos e Iluminação: José Agrippino de Paula

Elenco: Carlos Bellonzi, Daniele Palumbo, Manoel Domingues Filho, Juliana Carneiro da Cunha, Waldir Gonçalves, Ronaldo Leme, Paulo Roberto e elenco (além, é claro, dos Mutantes).

Espetáculo/show apresentado no teatro Casa Grande do Rio de Janeiro de Julho à Setembro de 1969.

\section{O Rito do Amor Selvagem (1969-1970)}

Direção e Figurinos: José Agrippino de Paula e Maria Esther Stockler

Roteiro: José Agrippino de Paula (a partir de seu "texto teatral” Nações Unidas)

Coreografia: Maria Esther Stockler

Preparação Corporal: Maria Esther Stockler e Yolanda Amadei

Cenografia e Iluminação: José Agrippino de Paula

Música e acompanhamento musical: Grupo "Sic Sunt Res"

Elenco: Stênio Garcia, Flávio Porto, Oiá Guareci, José Ramalho, Jairo Salvini, Clarice Piovesan, Fernando Benini, Carlos Martins, Doroty Leirner, Danielle Palumbo, Carlos Bellonzi, Edson Cavalcanti, Eudis Carvalho, Godot, Aguiar, Mirian e Sonia Goldfelder

O espetáculo estreou em Dezembro de 1969 no II Festival Paulista de Dança, desta vez realizado no Teatro São Pedro, recebendo em seguida um convite para prolongar a temporada nesse teatro por dois meses. Após esse tempo, o espetáculo ocupou o TBC, seguindo depois para o Teatro de Cimento Armado do Rio de Janeiro. Ao todo, o espetáculo permaneceu seis meses em cartaz. 